MARIELLA GUIMARÃES LACERDA

EFEITO DOS ORGANOESTÂNICOS SOBRE A ATIVIDADE TRANSCRICIONAL DE RECEPTORES NUCLEARES, ADIPOGÊNESE E INFLAMAÇÃO

EM CÉLULAS DE MAMÍFEROS 


\author{
UNIVERSIDADE DE BRASÍLIA \\ FACULDADE DE CIÊNCIAS DA SAÚDE \\ PROGRAMA DE PÓS-GRADUAÇÃO EM CIÊNCIAS DA SAÚDE
}

MARIELLA GUIMARÃES LACERDA

EFEITO DOS ORGANOESTÂNICOS SOBRE A ATIVIDADE TRANSCRICIONAL DE RECEPTORES NUCLEARES, ADIPOGÊNESE E INFLAMAÇÃO

EM CÉLULAS DE MAMÍFEROS

Tese apresentada como requisito parcial para a obtenção do título de Doutor em Ciências da Saúde pelo Programa de Pós-Graduação em Ciências da Saúde da Universidade de Brasília

Orientadora: Profa. Dra. Marie Togashi Co-orientador: Prof. Dr. Francisco de Assis Rocha Neves 


\section{EFEITO DOS ORGANOESTÂNICOS SOBRE A ATIVIDADE TRANSCRICIONAL DE RECEPTORES NUCLEARES, ADIPOGÊNESE E INFLAMAÇÃO EM CÉLULAS DE MAMÍFEROS}

Tese apresentada como requisito parcial para a obtenção do título de Doutor em Ciências da Saúde pelo Programa de Pós-Graduação em Ciências da Saúde da Universidade de Brasília

\section{BANCA EXAMINADORA}

Profa. Dra. Marie Togashi (Presidente) Universidade de Brasília

Profa. Dra. Adriana Lofrano Alves Porto Universidade de Brasília

Profa. Dra. Maria de Fátima Borin Universidade de Brasília

Prof. Dr. Luiz Cláudio Gonçalves de Castro Universidade de Brasília

Prof. Dr. Ranieri Rodrigues de Oliveira Centro Universitário de Brasília

Profa. Dra. Flora Aparecida Milton (Suplente) Universidade de Brasília 
Aos meus pais, Jayme (in memoriam) e Maria Angélica, pelo amor incondicional e por nunca terem poupado esforços para investir na minha educação.

Devo muito desta conquista a vocês!

Ao meu grande amor Aurélio, jamais conseguirei expressar com palavras toda a gratidão e admiração que sinto por você. Obrigada simplesmente por existir, me amar, me completar e me fazer feliz.

À minha irmã Marcela, minha melhor amiga e companheira de toda a vida. Obrigada pela amizade, conselhos, risadas e por me compreender tão bem, nem que seja por um simples olhar. 


\section{AGRADECIMENTOS}

À Marie Togashi, que além de orientadora, se tornou uma grande amiga. Obrigada por ter acreditado em mim, ter aberto as portas do laboratório e me inserido nesse maravilhoso mundo molecular. Foram inúmeros ensinamentos ao longo desses anos e, sem dúvida alguma, saio desta longa caminhada com um enorme crescimento profissional e pessoal. Devo muito desta conquista a você!

Ao meu co-orientador Professor Francisco de Assis Rocha Neves, pela oportunidade de trabalhar com você e por ter sido um exemplo profissional. Admiro muito os seus conhecimentos e agradeço pelos ensinamentos e sábios conselhos nos momentos mais difíceis.

À Flora minha grande amiga, e guerreira incansável, você não imagina o quanto admiro a sua competência. Sua amizade foi o maior presente ao longo do doutorado. Obrigada por poder contar sempre com você, pelas boas risadas que damos juntas e por toda a nossa cumplicidade. Agradeço o imenso apoio profissional, sua generosidade em compartilhar todos os seus conhecimentos e todos os ensinamentos, não tenho palavras para descrever a minha gratidão.

À Rilva, por todos os ensinamentos desde os primeiros passos na longa caminhada nesta nova área. Agradeço também pela amizade e paciência e por sempre estar disponível quando precisei de você.

À Angélica Amorim Amato, exemplo de profissional e ser humano, que cativa a todos com a sua inteligência e generosidade. Obrigada por acreditar no meu potencial e pelas oportunidades disponibilizadas. Minha eterna gratidão por ter me ajudado a superar difíceis obstáculos pessoais.

À Michella Soares Coelho, por ter se disponibilizado em me ajudar e por todo o tempo dedicado à minha formação. Agradeço o apoio no desenvolvimento do projeto do GQ-16.

Aos professores do Laboratório de Farmacologia Molecular (Farmol): Adriana Lofrano Alves Porto, Carine Royer, Djane Braz Duarte, Guilherme Martins Santos, Luiz Alberto Simeoni e Maria de Fátima Borin. Cada um de vocês contribuiu para a minha formação, muito obrigada por todos os ensinamentos!

À todos os meus colegas do Farmol: Adria, Alexandre, Bruna, Carolina, Caroline, Cínthia, Fernanda, Henrique, Isabel, Kaian, Natália, Olívia, Pedro, Sidney e 
Simone. Agradeço os momentos descontraídos que passamos juntos e por tornarem o dia a dia mais leve...

Ao Henrique Rodrigues de Oliveira pela imensa colaboração na fotodocumentação das placas de cultura de células.

Ao Luciano, técnico do Farmol, por trabalhar nos bastidores e colaborar para a realização dos nossos trabalhos.

Aos meus sogros Marco Tulio e Marlis, por terem me acolhido na nova família e por todo o apoio e torcida em todos os momentos desta caminhada.

À Gisele, ao Rodrigo e ao meu afilhado Francisco, que mais que amigos, se tornaram parte da minha família! Agradeço por todos os excelentes momentos que passamos juntos durante esta longa etapa da minha vida. 
"Existe uma coisa que uma longa existência me ensinou: toda a nossa ciência, comparada à realidade, é primitiva e inocente; e, portanto, é o que temos de mais valioso."

(Albert Einstein) 


\section{PREFÁCIO}

Devido ao acelerado crescimento econômico e industrial das últimas décadas, os efeitos dos poluentes ambientais sobre a saúde humana e de outros animais vem se tornando uma preocupação mundial. O mecanismo de ação de muitas destas substâncias ainda não foi esclarecido, mas já se sabe, por exemplo, que várias delas possuem atividade desreguladora endócrina (DE). Os DEs são compostos exógenos capazes de interferir no funcionamento do sistema endócrino e, além disso, dados de estudos recentes demonstram que muitos destes DEs também são potencialmente obesogênicos. Essa característica aumenta ainda mais o interesse por se explorar esses compostos, visto que a obesidade é uma epidemia mundial que predispõe o desenvolvimento de uma série de outras doenças, tais como diabetes mellitus tipo 2, dislipidemias e hipertensão arterial sistêmica.

Durante o doutorado desenvolvi um trabalho com um tipo de poluente ambiental pertencente à classe dos organoestânicos, os compostos de dibutilestanho (DBT). Os DBTs são amplamente utilizados na fabricação de materiais plásticos derivados do PVC (policloreto de polivinila), o que faz com que os seres humanos estejam constantemente em contato com os mesmos. Os resultados deste estudo mostraram que os DBTs são agonistas dos receptores nucleares PPARY (receptor ativado por proliferadores peroxissomais do tipo gama) e RXRa (receptor retinóide $X$ do tipo alfa) e que possuem atividade DE promovendo a adipogênese em células 3T3-L1. Esperamos que, juntamente com outros estudos, esses resultados ajudem a compreender como esses compostos podem afetar a saúde humana.

Os resultados parciais desta pesquisa com os organoestânicos foram apresentados em 2015 no Endocrine Society Annual Meeting (ENDO 2015) e agora, com o trabalho finalizado, a expectativa é que o mesmo seja publicado em periódico científico.

Um outro trabalho que desenvolvi durante o doutorado foi com o GQ-16, um agonista parcial do PPARy que promove a melhora da resistência à insulina sem provocar ganho de peso. O objetivo deste estudo foi investigar os efeitos deste novo ligante sintético de PPARY sobre a expressão de genes no coração de camundongos com obesidade e resistência à insulina induzidas por dieta. Pelo fato 
das tiazolidinadionas (TZDs) aumentarem o risco de mortes por causas cardiovasculares, optou-se por se comparar os mecanismos de ação de um agonista total (rosiglitazona, uma TZD) e um parcial (GQ-16) na tentativa de ajudar a elucidar os efeitos de ligantes de PPARy neste tecido.

Este estudo com o GQ-16 encontra-se em andamento e os resultados parciais, expostos no Apêndice B deste documento, também foram apresentados em 2015 no Endocrine Society Annual Meeting (ENDO 2015).

Atualmente, também estou inserida em um projeto de pesquisa com o intuito de investigar as interações medicamentosas entre fármacos convencionais e as espécies vegetais constantes na Relação Nacional de Plantas Medicinais de Interesse do Sistema Único de Saúde (RENISUS). Este estudo encontra-se em andamento e, dentre outros objetivos, está incluída a investigação da atividade agonista ou antagonista destes extratos no PXR (receptor pregnano X). 


\section{RESUMO}

Os organoestânicos são um grupo de compostos formados por um átomo de estanho ligado covalentemente a um ou mais grupamentos orgânicos. Dentre estes, o mais estudado é o cloreto de tributilestanho (TBT), um poluente ambiental com atividade desreguladora endócrina. No entanto, há poucos estudos com outros organoestânicos, como por exemplo, os dibutilestanho (DBT). O objetivo deste estudo foi investigar o efeito do diacetato, dicloreto, dilaurato e maleato de DBT sobre a atividade transcricional dos receptores nucleares PPARY e RXR e sobre a adipogênese e a inflamação em cultura de células de mamíferos. De forma semelhante ao cloreto de TBT, em ensaios de gene repórter, foi observado que o diacetato, o dicloreto, o dilaurato e o maleato de DBT são agonistas parciais do PPARy. Ao contrário do cloreto de TBT, agonista total do RXRa, o dicloreto e o dilaurato de DBT são agonistas parciais do RXRa. Além disso, a introdução da mutação C285S, que impede a ligação do cloreto de TBT ao PPARY, aboliu a atividade transcricional deste receptor induzida por todos os compostos, sugerindo que eles se ligam ao PPARY de modo similar ao cloreto de TBT. Em pré-adipócitos 3T3-L1, todos os DBTs induziram a adipogênese via PPARy, embora em menor intensidade que a rosiglitazona e o cloreto de TBT. Este efeito foi confirmado pela expressão dos marcadores adipogênicos Fabp4, Adipoq e Glut4. O co-tratamento das células 3T3-L1 com os DBTs e o T0070907, antagonista específico de PPARY, reduziu o acúmulo lipídico, sugerindo que este efeito adipogênico ocorre via PPARY. Além disso, o dicloreto, o dilaurato e o maleato de DBT reprimiram a expressão de genes associados à resposta inflamatória, tais como o Dcn, Fn1 e Vcam1, apesar desses efeitos terem sido menos intensos que o da rosiglitazona e do cloreto de TBT. De maneira interessante, em células RAW 264.7, apenas o cloreto de TBT e o dilaurato de DBT diminuíram a expressão de TNFa induzida por LPS. Esses achados mostram que o diacetato, o dicloreto, o dilaurato e o maleato de DBT são agonistas parciais do PPARy. Ainda, o cloreto de TBT e os compostos de DBT induzem a adipogênese e reprimem genes associados à resposta inflamatória em cultura de células de mamíferos.

Palavras-chave: receptor ativado por proliferadores peroxissomais do tipo gama; receptor retinóide $X$ do tipo alfa; tributilestanho; dibutilestanho; adipogênese; genes associados à resposta inflamatória 


\begin{abstract}
Organotins is a group of different chemical compounds that have a tin atom covalently bound to one or more organic groups. The best studied organotin is tributyltin chloride (TBT chloride) which is environmental pollutant and an endocrine disruptor. However, there are few studies with other organotin compounds, such as dibutyltin (DBT). The aim of this study was to investigate the effect of DBTs diacetate, dichloride, dilaurate, and maleate on the transcriptional activity of the nuclear PPARY and RXRa receptors, and on adipogenesis and inflammation in mammalian cell cultures. Analogous to TBT chloride, in reporter gene assay, it was observed that DBTs diacetate, dichloride, dilaurate, and maleate are partial agonists of PPARY. Unlike TBT chloride, which is a full agonist of RXRa, DBTs dichloride, and dilaurate are partial RXRa agonists. Additionally, the introduction of the C285S mutation, which disrupts TBT chloride binding to PPARy, abrogated the DBTs compounds transcription activity, suggesting that these compounds binds to PPARY in the same binding pocket as TBT chloride. In preadipocytes 3T3-L1 cells, all DBTs induced adipogenesis in a PPARY-dependent manner, although slighter than rosiglitazone and TBT chloride. This effect was confirmed by the expression of adipogenic markers such as Fabp4, Adipoq, and Glut4. Co-treatment of 3T3-L1 cells with DBTs and T0070907, a specific PPARY antagonist, reduced fat accumulation, suggesting that this adipogenic effect occurs through PPARY. Furthermore, DBTs dichloride, dilaurate, and maleate inhibited the expression of inflammatory responserelated genes such as Dcn, Fn1, and Vcam1, even though these effects were weaker than rosiglitazone and TBT chloride. Interesting, in RAW 264.7 cells, TNFa expression induced by LPS was diminished only by TBT chloride and DBT dilaurate. These findings indicate that DBTs diacetate, dichlorate, dilaurate, and maleate are PPARY partial agonists. Furthermore, TBT chloride and DBTs compounds induce adipogenesis and repress inflammatory response-related genes in mammalian cell cultures.
\end{abstract}

Keywords: peroxisome proliferator activated receptor gamma; retinoid $\mathrm{X}$ receptor alpha; tributyltin; dibutyltin; adipogenesis; inflammatory response-related genes 


\section{LISTA DE ILUSTRAÇÕES}

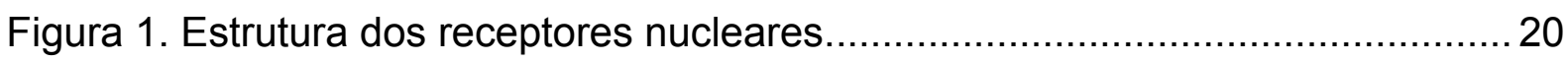

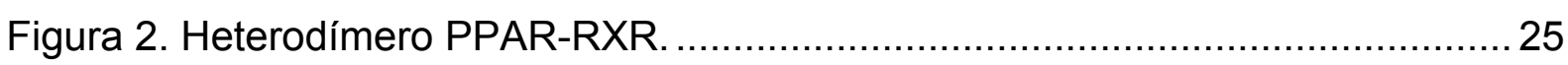

Figura 3. Mecanismos de controle da atividade transcricional pelos PPARs........... 26

Figura 4. Estrutura química, peso molecular e fórmula linear do cloreto de

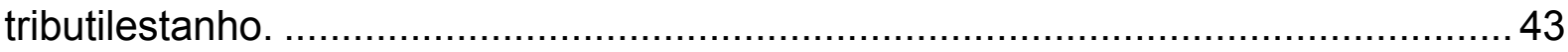

Figura 5. Estrutura química, peso molecular e fórmula linear dos compostos de

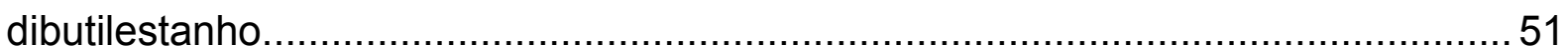

Figura 6. Ensaio de diferenciação de células 3T3-L1 …....................................... 62

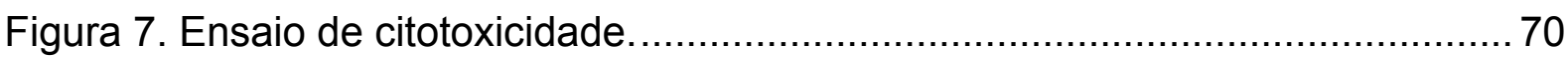

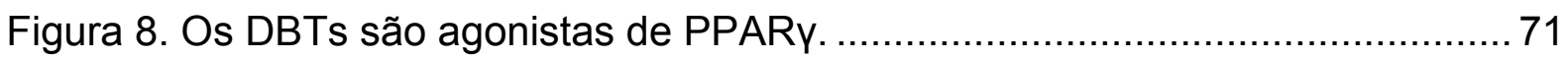

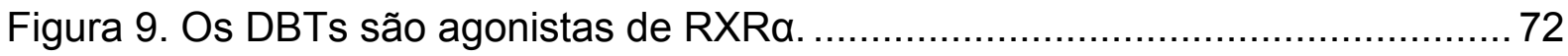

Figura 10. A cisteína 285 é importante para a ativação do PPARy pelos DBTs. ......73

Figura 11. Os DBTs induzem a adipogênese em cultura de células 3T3-L1 ........... 74

Figura 12. O efeito adipogênico dos DBTs é dependente do PPARY.....................75

Figura 13. Os DBTs reprimem genes relacionados à resposta inflamatória em células 3T3-L1. 76

Figura 14. Os DBTs reprimem genes associados à resposta inflamatória em células RAW 264.7. 77 


\section{LISTA DE ABREVIATURAS E SIGLAS}

15d-PGJ2 prostaglandina J2 (15-Deoxy-Delta-12, 14-prostaglandin J2)

Adipoq adiponectina (adiponectin)

AF-1 função de ativação 1 (activation function 1)

AF-2 função de ativação 2 (activation function 2)

AP-1 proteína ativadora 1 (activating protein-1)

AR receptor de andrógeno (androgen receptor)

ATP trifosfato de adenosina

BPA bisfenol A (bisphenol A)

C carbono

C/EBPs proteínas de ligação ao amplificador CCAAT (CCAAT-enhancerbinding proteins)

CAR

receptor androstano constitutivo (constitutive androstane receptor)

Cdk5 ciclina dependente de quinase 5 (cyclin-dependent kinase 5)

CONAMA Conselho Nacional do Meio Ambiente

Cys cisteína (cysteine)

DBD domínio de ligação ao DNA (DNA binding domain)

DBT dibutilestanho (dibutyltin)

Den decorina (decorin)

DDT dicloro-difenil-tricloroetano (dichlorodiphenyltrichloroethane)

DE desregulador endócrino

DES dietilestilbestrol (diethylstilbestrol)

DMEM Dulbecco's Modified Eagle Medium

DMSO dimetilsulfóxido (dimethyl sulfoxide)

DR-1 repetição direta 1 (direct repetition 1)

ER receptor de estrógeno (estrogen receptor)

ERR receptor relacionado ao estrógeno (estrogen receptor-related receptor)

Fabp4 proteína ligadora de ácido graxo 4 (fatty acid binding protein 4)

FAT/CD36 translocase de ácido graxo CD36 (fatty acid translocase CD36)

Fn1 fibronectina 1 (fibronectin 1)

FXR receptor farnesóide $X$ (farnesoid $X$ receptor) 
GAL4 fator de transcrição de leveduras

Gapdh gliceraldeído-3-fosfato desidrogenase (glyceraldehyde-3-phosphate dehydrogenase)

Glut4 transportador de glicose tipo 4 (glucose transporter type 4)

GR receptor de glicocorticóide (glucocorticoid receptor)

$\mathrm{H}$ hélice

HADCs histonas deacetilases (histone deacetylases)

HNF4 fator nuclear hepatocitário 4 (hepatocyte nuclear factor 4)

HREs elementos responsivos aos hormônios (hormone response elements)

IBMX isobutilmetilxantina (isobutylmethylxanthine)

IL interleucina (interleukin)

iNOS óxido nítrico sintase induzível (inducible nitric oxide synthase)

IRS1

LBD

LPS substrato 1 do receptor de insulina (insulin receptor substrate 1) domínio de ligação ao ligante (ligand binding domain)

LRH1 lipopolissacarídeo receptor humano homólogo 1 hepático (human liver receptor homologue-1)

LXR receptor hepático $X$ (liver $X$ receptor)

MR receptor de mineralocorticóide (mineralocorticoid receptor) mRNA RNA mensageiro brometo tiazolil azul de tetrazólio $\mathrm{NCoR}$ correpressor do receptor nuclear (nuclear receptor corepressor) $\mathrm{NF}-\mathrm{KB}$ fator nuclear kappa B (factor nuclear kappa B)

NORMAN Normas da autoridade marítima para o controle de sistemas antiincrustantes em embarcações

NR4A receptor nuclear 4A (nuclear receptor $4 A$ )

oxoETEs ácidos eicosatetraenóicos oxidados oxoLDL lipoproteínas oxidadas de baixa densidade PBBs bifenilos polibromados (polybrominated biphenyls) PBDEs éteres difenílicos polibromados (polybrominated diphenyl ethers) PCBs bifenilos policlorados (polychlorinated biphenyls) POPs poluentes orgânicos persistentes (persistent organic pollutant) PPAR receptor ativado por proliferadores peroxissomais (peroxisome proliferator-activated receptor) 
PPREs elementos responsivos aos proliferadores peroxissomais (peroxisome proliferator response elements)

PR receptor de progesterona (progesterone receptor)

Pref-1 proteína associada a diferenciação de adipócitos (adipocyte differentiation-associated protein)

PVC policloreto de polivinila (polyvinyl chloride)

$\mathrm{PXR} \quad$ receptor pregnano $\mathrm{X}$ (pregnane $\mathrm{X}$ receptor)

RAR receptor do ácido retinóico (retinoic acid receptor)

RN receptor nuclear (nuclear receptor)

ROR receptor órfão relacionado ao retinóide (retinoid-related orphan receptor)

RT-qPCR transcrição reversa seguida por reação em cadeia da polimerase em tempo real/quantitativa

$\mathrm{RXR} \quad$ receptor retinóide $\mathrm{X}$ (retinoid $X$ receptor)

SF1 fator esteroidogênico 1 (steroidgenic factor-1)

SHP parceiro heterodímero curto (short heterodimer partner)

SMRT mediador do silenciamento dos receptores retinóide e do hormônio tireoidiano (silencing mediator for retinoid and thyroid hormone receptors)

Sn estanho

SUMO small ubiquitin-like modifier

TBT tributilestanho (tributyltin)

TNFa fator de necrose tumoral alfa (tumor necrosis factor alpha)

TR receptor do hormônio tireoidiano (thyroid hormone receptor)

TR receptor testicular (testicular receptor)

TZD tiazolidinadionas

Vcam1 molécula 1 de adesão celular vascular (vascular cell adhesion molecule 1)

VDR receptor da vitamina D (vitamin $D$ receptor) 


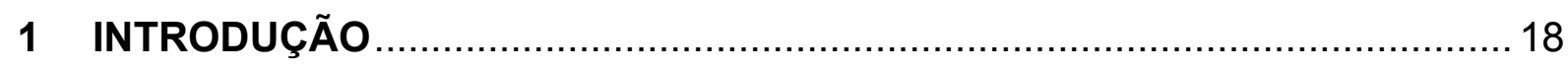

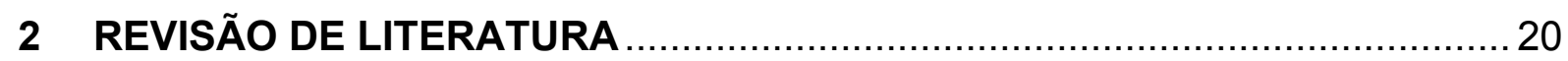

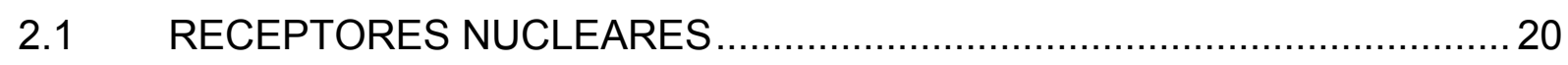

2.1.1 Receptores Ativados por Proliferadores Peroxissomais …................. 23

2.1.1.1 Receptores Ativados por Proliferadores Peroxissomais do Tipo Gama ... 28

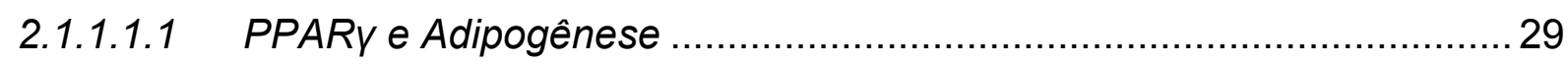

2.1.1.1.2 PPARY, Resistência à Insulina e Inflamação....................................... 31

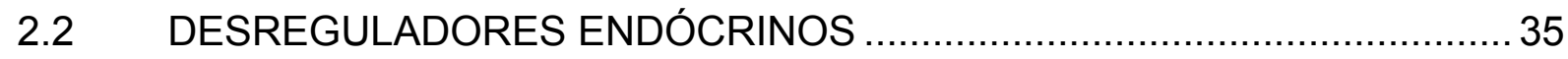

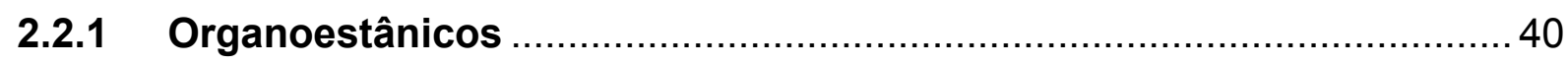

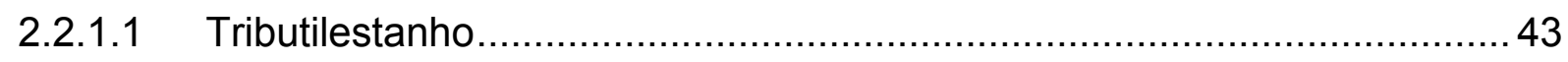

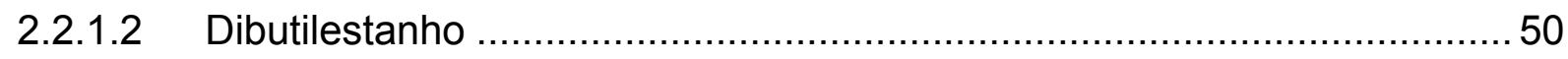

3 OBJETIVOS

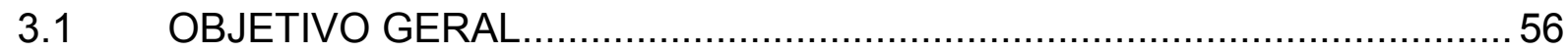

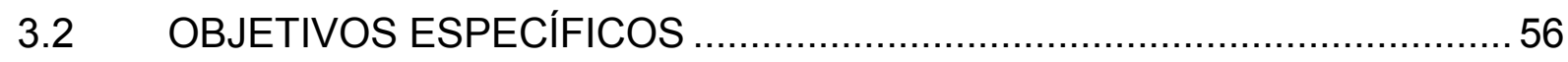

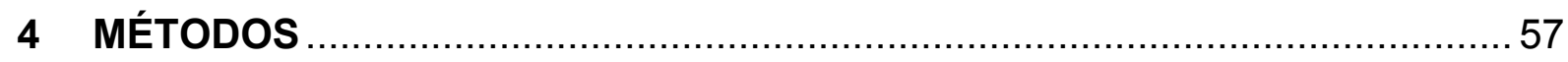

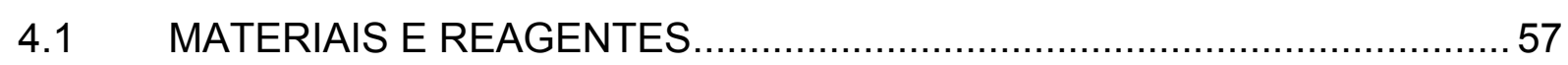

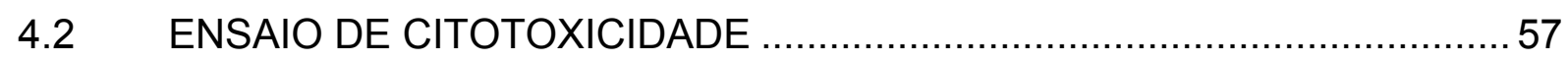

4.3 ENSAIO DE TRANSFECÇÃO E GENE REPÓRTER …............................59

4.4 ENSAIO DE DIFERENCIAÇÃO DE ADIPÓCITOS …...............................61

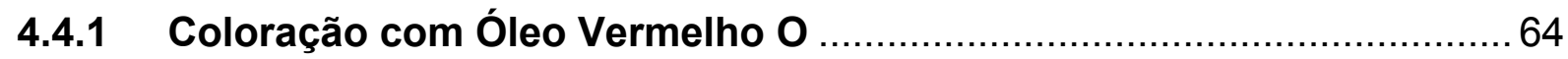

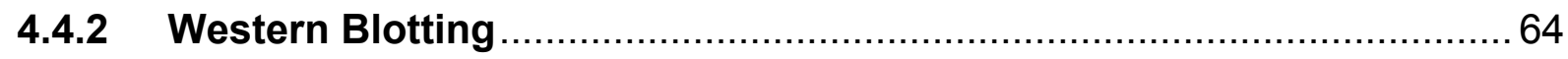

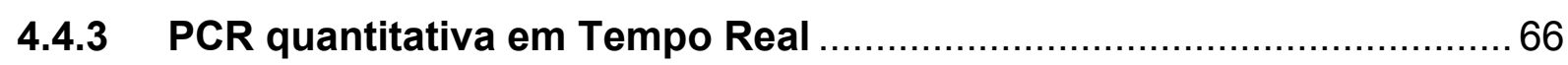

4.5 ENSAIO DE ESTIMULAÇÃO DE MACRÓFAGOS COM LPS .....................69

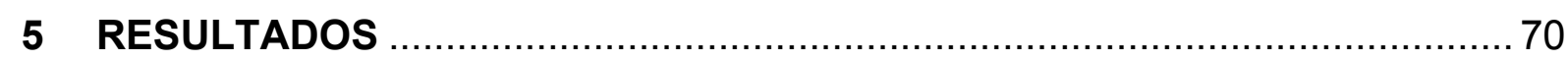

5.1 AVALIAÇÃO DA CITOTOXICIDADE DOS COMPOSTOS DE DBT ............70

5.2 OS DBTS SÃO AGONISTAS DE PPARY E RXRa .................................71

5.3 A CISTEÍNA 285 É IMPORTANTE PARA A ATIVAÇÃO DO PPARY PELOS

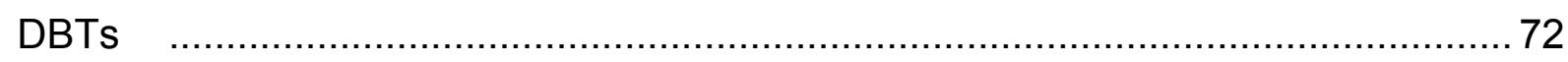

5.4 OS DBTS INDUZEM A ADIPOGÊNESE EM CULTURA DE CÉLULAS ......73

5.5 O EFEITO ADIPOGÊNICO DOS DBTS É DEPENDENTE DO PPARY .......75 
5.6 OS DBTS REPRIMEM GENES RELACIONADOS À RESPOSTA INFLAMATÓRIA EM CULTURA DE CÉLULAS ………..................................76

6 DISCUSSÃO

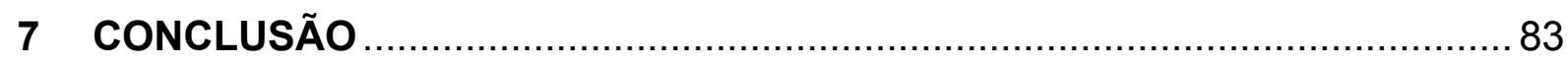

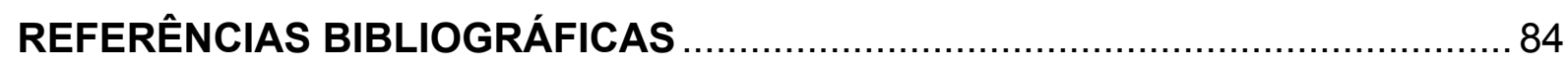

APÊNDICE A - INFORMAÇÕES SOBRE OS PRIMERS …................................ 106

APÊNDICE B - EFEITO DO GQ-16 SOBRE A EXPRESSÃO DE GENES NO CORAÇÃO DE CAMUNDONGOS COM OBESIDADE E RESISTÊNCIA À

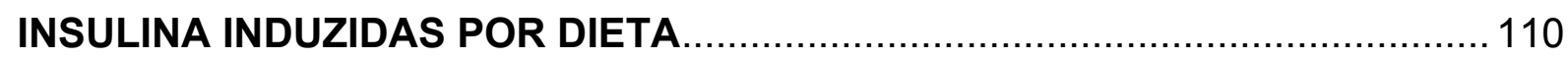

ANEXO A - DOCUMENTO DE APROVAÇÃO PELA COMISSÃO DE ÉTICA NO USO DE ANIMAIS - CEUA/FM 


\section{INTRODUÇÃO}

Após a Segunda Guerra Mundial, uma grande "revolução química sintética" vem ocorrendo e causando uma significativa transformação no ambiente no qual vivem diferentes espécies $(1,2)$. Desde então, uma série de produtos químicos têm sido produzidos e espalhados no meio ambiente fazendo com que os humanos e diversos animais, convivam, quase que obrigatoriamente, com essas substâncias (3).

Ainda não se sabe quais são os efeitos da maioria desses compostos sobre o funcionamento de sistemas biológicos. Entretanto, eles são considerados potenciais fontes causadoras de danos aos seres vivos devido a algumas de suas propriedades como lipossolubilidade, estabilidade química, degradação lenta, toxicidade e bioacumulação (3-5). Além disso, também há evidências de que várias destas substâncias interferem no funcionamento do sistema endócrino, atuando como desreguladores endócrinos (DEs) (3).

A estrutura química dos DEs é bastante variada, no entanto eles possuem algumas características comuns como, hidrofobicidade, alta solubilidade em lipídeos e tamanho reduzido, em geral com massa molecular máxima de 1000 Daltons $(3,5)$. Grande parte dos DEs exercem seus efeitos via membros da superfamília de receptores nucleares, tais como os receptores de estrógeno (ERa e ERß), de progesterona (PR), de glicocorticóide (GR), do hormônio tireoidiano (TRa e TRß), receptores retinóide do tipo $X(R X R \alpha, \beta$ e $y)$ e os receptores ativados por proliferadores peroxissomais (PPAR $\alpha, \beta / \delta$ e ) (6).

Inclusive, muitos desses DEs são considerados potenciais obesogênicos por causarem hiperplasia e/ou hipertrofia de adipócitos e, desta forma, promoverem a obesidade $(7,8)$.

Em 2002, surgiram os primeiros trabalhos sugerindo que, juntamente com outros fatores, pode haver uma associação entre o crescimento da incidência da obesidade e o aumento da presença de diversos produtos químicos no meio ambiente (9). A partir daí, vários outros estudos foram realizados, tanto em modelos animais $(10,11)$ quanto em humanos $(12-14)$ demonstrando que uma série de compostos químicos são capazes de induzir a adipogênese podendo contribuir para o desenvolvimento da obesidade e dos distúrbios associados a esta doença, tais 
como o diabetes mellitus tipo 2, a resistência à insulina e a dislipidemia.

O cloreto de tributilestanho (TBT) é um dos DEs potencialmente obesogênico mais encontrados no meio ambiente e um dos mais pesquisados (15). Este composto já foi amplamente utilizado como pintura anti-incrustante em barcos, navios e estaleiros (16). Entretanto, seu uso foi proibido em 2008 devido aos seus já comprovados riscos para os ecossistemas marinhos $(17,18)$. Atualmente, é usado como estabilizador na fabricação do policloreto de polivinila (PVC) e também como catalisador em diversos processos industriais (19). Os resultados de diversos estudos mostram que a exposição ao cloreto de TBT induz a adipogênese em cultura de células, por meio da ativação do receptor ativado por proliferadores peroxissomais do tipo gama (PPARy) $(20,21)$. Além disso, provoca em modelos animais, dentre outros efeitos, esteatose hepática, ganho de peso corporal, hiperinsulinemia e aumento da massa do tecido adiposo visceral $(22,23)$.

O dibutilestanho (DBT) é um outro exemplo de poluente ambiental que pertence ao grupo dos organoestânicos (24). Os DBTs são utilizados, principalmente, como estabilizadores e catalisadores na fabricação de materiais plásticos e de borracha, mas também como biocidas. Com todas essas aplicações, podem ser encontrados em diversos produtos amplamente utilizados pelos seres humanos, tais como canos de água, pneus, roupas, pisos, luvas, embalagens alimentares dentre outros (25-27).

Assim como o cloreto de TBT, o dicloreto de DBT é potencialmente hepatotóxico (28), imunotóxico (29) e neurotóxico (30). Porém, ao contrário do cloreto de TBT, há poucos trabalhos que investigaram os efeitos biológicos decorrentes da exposição aos compostos de DBT. Além disso, quando realizados são focados principalmente em apenas um tipo, no dicloreto de DBT.

Baseado no que foi exposto, a proposta deste trabalho foi buscar compreender alguns dos mecanismos moleculares e celulares envolvidos na ação de quatro tipos de DBTs, o diacetato, o dicloreto, o dilaurato e o maleato de DBT, compostos com os quais os seres humanos estão frequentemente em contato e que carecem de estudos em relação aos seus efeitos na saúde humana. 


\section{REVISÃO DE LITERATURA}

\subsection{RECEPTORES NUCLEARES}

Os receptores nucleares (RNs) são fatores de transcrição que regulam diversas funções biológicas, tais como a homeostase, a reprodução, o desenvolvimento e o metabolismo $(31,32)$.

Os RNs apresentam uma organização estrutural comum formada por diferentes regiões, denominadas domínios, que podem executar suas funções de maneira autônoma (33). A Figura 1 ilustra a estrutura dos RN, que de uma forma geral são constituídos pela porção amino terminal (A/B), um domínio de ligação ao DNA (DNA binding domain - DBD) (C), uma região denominada de dobradiça (hinge) (D) e o domínio de ligação ao ligante (ligand binding domain - LBD) (E). Alguns receptores também contêm um domínio $\mathrm{F}$ localizado na região carboxiterminal, cuja função ainda é desconhecida (32-34).

(A)

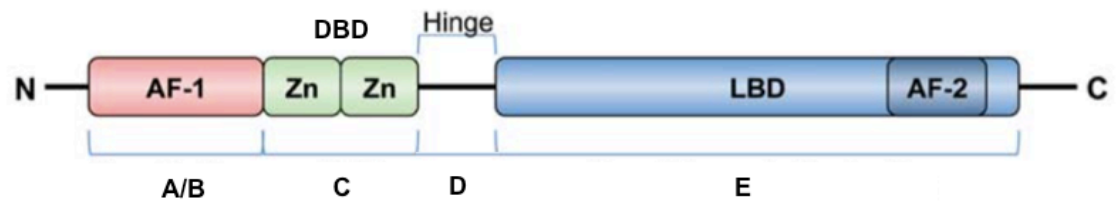

(B)

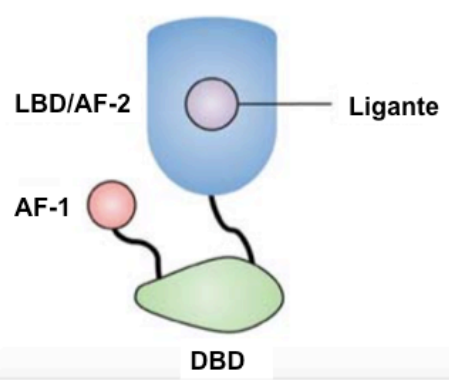

Figura 1. Estrutura dos receptores nucleares.

(A) Estrutura primária mostrando o domínio amino-terminal $(A / B)$ no qual se encontra o domínio de função de ativação 1 (AF-1), que ativa a transcrição independente do ligante; domínio de ligação ao DNA ou DBD (C), onde se localizam os dois dedos de zinco (Zn); Hinge ou dobradiça (D); domínio de ligação ao ligante ou LBD (E) onde fica a função de ativação 2 (AF-2); porção amino terminal (N) e carboxiterminal $(C)$. Alguns receptores nucleares possuem ainda um domínio $F$, não ilustrado na figura. (B) Estrutura secundária mostrando os domínios AF-1, DBD e LDB/AF-2 na presença do ligante. (Figura adaptada de Choi J-M, Bothwell ALM. The Nuclear Receptor PPARs as Important Regulators of T-Cell Functions and Autoimmune Diseases. Molecules and Cells. 2012; 33(3): 217-222 (35)). 
O domínio amino terminal é altamente variável entre os RNs, tanto em relação à sua sequência quanto ao seu tamanho, podendo ter de 50 até mais de 500 aminoácidos. Contém uma região denominada de AF-1 (função de ativação 1 activation function 1) que ativa a transcrição independente da presença do ligante $(32,33,36)$. Também é nesta região que vários RNs são fosforilados, um tipo de modificação pós-traducional que pode afetar significativamente a atividade transcricional dos receptores (33).

O DBD é o domínio mais conservado dos receptores nucleares. Contém nove cisteínas, além de outros resíduos que são preservados entre os membros da superfamília de receptores nucleares $(33,36)$. A sua principal função é reconhecer e promover a ligação do receptor a regiões específicas do DNA que ficam nos promotores de seus genes alvo. Estas regiões são denominadas de elementos responsivos aos hormônios (hormone response elements - HREs) (32, 34, 37). Este domínio também possui dois dedos de zinco (motivos de ligação ao DNA formados por cerca de 60 a 70 aminoácidos), duas alfa hélices e uma extensão carboxila. $\mathrm{Na}$ base do primeiro dedo de zinco, em uma região denominada de "P box", localizamse os aminoácidos que reconhecem os HREs. Já na "D box", que fica no segundo dedo de zinco, estão os outros resíduos que participam da dimerização do RN (33).

O domínio $D$ não é muito conservado entre os RNs e também pode ser denominada de região de dobradiça pelo fato de servir como uma articulação entre o DBD e o LBD, permitindo a rotação do DBD e a interação dos RNs com múltiplas sequências de HREs $(33,36)$.

No LBD são realizadas variadas funções e é nesta região que ocorre a dimerização do receptor (homo ou heterodimerização), a ligação dos ligantes e a associação do receptor a proteínas coativadoras e correpressoras. Neste domínio, também está localizado o motivo AF-2 (função de ativação 2 - activation function 2) que é responsável pela ativação transcricional dependente do ligante $(32-34,37)$. As estruturas cristalográficas dos LBDs de vários RNs mostram que este domínio contém 12 a-hélices numeradas de 1 a 12 (H1 a H12) e uma folha $\beta$-pregueada (localizada entre as $\mathrm{H} 5$ e H6) conservadas. Estas estruturas se dobram formando uma cavidade, predominantemente hidrofóbica, denominada de bolso de ligação, local onde o ligante se liga ao RN. O tamanho deste sítio de ligação é extremamente variável entre os $\mathrm{RNs}(6,33)$. 
Os seres humanos expressam 48 tipos de receptores nucleares que podem ser classificados em três grupos, dependendo da sua função e dos seus ligantes fisiológicos $(32,36,37)$.

O primeiro grupo é formado pelos receptores endócrinos, que possuem alta afinidade por hormônios lipossolúveis e vitaminas, tais como os TRs (receptores de hormônio tireoidiano - thyroid hormone receptors), o VDR (receptor da vitamina D vitamin $D$ receptor) e o RAR (receptor do ácido retinóico - retinoic acid receptor). Também fazem parte desse grupo os receptores de hormônios esteróides, como o ER (receptor de estrógeno - estrogen receptor), o PR (receptor de progesterona progesterone receptor), o AR (receptor de andrógeno - androgen receptor), o GR (receptor de glicocorticóide - glucocorticoid receptor) e o MR (receptor de mineralocorticóide - mineralocorticoid receptor). Os receptores de esteróides agem como homodímeros, enquanto que o TR, o VDR e o RAR formam heterodímeros com o RXR (receptor retinóide $X$ - retinoid $X$ receptor), sendo todos essenciais à manutenção da homeostase e funcionamento do sistema endócrino (36).

O segundo grupo é denominado de receptores órfãos adotados. Eram considerados órfãos, por não possuírem nenhum ligante natural, e passaram a ser denominados adotados após a identificação dos mesmos. O primeiro RN adotado foi o RXR, depois da identificação do seu ligante endógeno com o qual ele apresenta alta afinidade, o ácido 9-cis retinóico. Estão incluídos nesse grupo os receptores que apresentam baixa afinidade para lipídeos dietéticos e xenobióticos, como por exemplo: o RXR, o LXR (receptor hepático $X$ - liver $X$ receptor), o FXR (receptor farnesóide $X$ - farnesoid $X$ receptor), o PXR (receptor pregnano $X$ - pregnane $X$ receptor) e os PPARs (receptores ativados por proliferadores peroxissomais peroxisome proliferator-activated receptors). Todos agem heterodimerizados com o $R X R$, podendo ou não ser ativados por ligantes deste último (são então considerados como permissivos ou não permissivos, respectivamente), sendo essenciais para a regulação da homeostase de lipídeos e de carboidratos (36).

Dentro deste segundo grupo de receptores órfãos adotados, há também os receptores órfãos enigmáticos adotados. São assim denominados por possuírem um ligante identificado para pelo menos um subtipo, sem no entanto estarem esclarecidos os mecanismos de regulação da atividade transcricional dependente do ligante. Exemplos: o LRH1 (receptor humano homólogo 1 hepático - human liver receptor homologue-1), o HNF4 (fator nuclear hepatocitário 4 - hepatocyte nuclear 
factor 4), o ERR (receptor relacionado ao estrógeno - estrogen receptor-related receptor), o CAR (receptor androstano constitutivo - constitutive androstane receptor), o SF1 (fator esteroidogênico 1 - steroidgenic factor-1) e o ROR (receptor órfão relacionado ao retinóide - retinoid-related orphan receptor) (36).

O terceiro grupo é formado pelos verdadeiros receptores órfãos, já que não possuem ligantes naturais ou sintéticos identificados. Alguns exemplos são: o SHP (parceiro heterodímero curto - short heterodimer partner), o TR (receptor testicular testicular receptor) e o NR4A (receptor nuclear 4A - nuclear receptor 4A). É bem provável que a atividade destes receptores seja regulada por sua própria expressão, pela disponibilidade de proteínas coativadoras, por modificações covalentes ou por uma combinação desses fatores. Há também evidências de que alguns deles possam estar envolvidos na regulação do metabolismo (36).

Os RNs também podem ser classificados de acordo com um Sistema Unificado de Nomenclatura para a Superfamília de Receptor Nuclear, criado em 1999. Baseado em uma árvore filogenética, que conecta todas as sequências de RNs nucleares conhecidas, os mesmos são identificados baseados nas subfamílias e nos grupos ao quais pertencem. O TRa, por exemplo, é identificado como NR1A1 $(\mathrm{NR}=$ nuclear receptor; subfamília 1 ; grupo $\mathrm{A} ; 1$ = número que identifica $\mathrm{O}$ TRa especificamente), enquanto o TRß, que pertence à mesma subfamília e grupo, recebe a designação NR1A2. Os autores podem continuar se referindo aos RNs utilizando os seus nomes tradicionais, a recomendação é que pelo menos uma vez ao longo do trabalho o mesmo seja identificado utilizando o sistema de letras e números (38).

\subsubsection{Receptores Ativados por Proliferadores Peroxissomais}

Os receptores ativados por proliferadores peroxissomais (PPARs) são fatores de transcrição regulados por ligantes que pertencem à superfamília de receptores nucleares $(39,40)$. Os PPARs receberam este nome devido à sua capacidade de se ligar a substâncias químicas conhecidas por induzir a proliferação de peroxissoma em roedores (41). Estas organelas contribuem para a oxidação de ácidos graxos, 
porém a sua proliferação pode resultar em hepatomegalia e carcinogênese em roedores (41), efeitos que felizmente não são observados em seres humanos (39).

Os PPARs controlam uma série de genes que estão envolvidos na adipogênese, metabolismo lipídico, inflamação, diferenciação celular e na manutenção do equilíbrio metabólico e do balanço energético. Existem três isoformas deste receptor, o PPAR $\alpha$, o PPAR $\beta / \delta$ e o PPARy, codificadas cada uma por um gene, reguladas por diferentes ligantes e que também se diferem em relação à expressão tecidual $(39,40,42)$.

Em 1990 foi clonado o primeiro isotipo dos receptores ativados por proliferadores peroxissomais, o PPARa (NR1C1) (41). Ele encontra-se altamente expresso em tecidos com elevadas taxas de oxidação de ácidos graxos, como fígado, intestino, coração, rins e tecido adiposo marrom (43) e sua principal função é regular a homeostase energética (44). No tecido hepático, o PPARa estimula a oxidação de ácidos graxos, a gliconeogênese e a cetogênese. E este aumento da oxidação de ácidos graxos decorrente da ativação deste receptor reduz os níveis de triglicerídeos circulantes, a esteatose muscular e hepática e também a adiposidade, o que melhora a resistência à insulina (40).

Logo depois, em 1992, foram identificados e caracterizados mais dois isotipos de PPARs, o PPARß/ס (NR1C2) e o PPARY (NR1C3). O isotipo PPARß/ס foi denominado inicialmente de PPAR $\beta$ quando foi isolado pela primeira vez de uma biblioteca de oócitos de Xenopus (45). Em seguida, quando foi identificado que a sequência da proteína do PPARß de mamíferos não apresentava uma alta homologia com a proteína do PPAR $\beta$ de Xenopus, recebeu o nome de PPARס (pois acreditava-se terem descoberto o quarto membro desta família de receptores) (42). Entretanto, mais adiante descobriu-se que os PPARs de mamíferos e Xenopus eram ortólogos do PPARß de anfíbios. A partir daí, foi então proposto que este receptor fosse designado como PPARß/ठ (40). Dentre os três tipos de PPARs, é o que possui expressão tecidual mais ampla podendo ser encontrado na pele, intestino, placenta, músculo esquelético, tecido adiposo e cérebro (43). O PPAR $\beta / \delta$ participa do processo de proliferação e diferenciação celular e também está envolvido no mecanismo de reparo tecidual. Além disso, controla a homeostase energética estimulando a expressão de genes envolvidos na oxidação de ácidos graxos (40, 46). 
O PPARy é expresso principalmente no tecido adiposo, sendo considerado o regulador chave da adipogênese (47). Por ser o foco do presente estudo, mais adiante serão dadas mais informações sobre este receptor.

Os PPARs apresentam a organização estrutural comum dos receptores nucleares, formada por domínios e que já foi descrita anteriormente. Apenas o LBD destes receptores possui algumas características que são específicas desta família de RNs como: (i) ser formado por 13 alfa hélices, ao invés das 12 que são observadas nos demais RNs. A hélice extra, denominada de H2', fica localizada entre a primeira folha $\beta$ pregueada e a H3; (ii) apresentar um bolso de ligação em forma de $\mathrm{Y}$ e bastante amplo, com uma cavidade maior que o da maioria dos $\mathrm{RN}$ e (iii) exibir a volta entre as H2' e a H3, localizada na entrada do bolso de ligação, muito flexível, o que permite que grandes ligantes se liguem sem alterar significativamente a estrutura do receptor (48).

Os PPARs executam suas ações na forma de heterodímeros, associados aos RXRs (NR2B) $(49,50)$, estes últimos, designados como "receptores promíscuos" por heterodimerizarem-se com uma série de outros RNs, como o TR, o VDR e o RAR (33). Este heterodímero pode se formar tanto na ausência como na presença do ligante (40), sendo considerado um dímero permissivo, pois pode ser ativado por ligantes de PPARs ou de RXR, ou sinergicamente na presença dos ligantes dos dois receptores (33). Os elementos responsivos dos PPARs, denominados de PPREs (peroxisome proliferator response elements), localizam-se nos promotores dos genes alvos de PPAR e são constituídos de repetições diretas da sequência consenso AGGTCA espaçada por um nucleotídeo, denominada de DR-1 (repetição direta 1 - direct repetition 1) (49) (Figura 2).

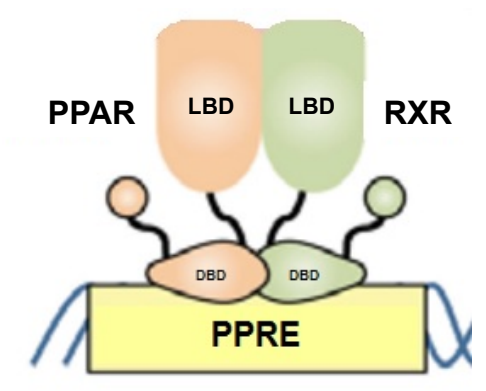

Figura 2. Heterodímero PPAR-RXR.

Os PPARs executam as suas ações na forma de heterodímeros associados ao RXR e se ligam a sequências específicas de DNA localizadas nos promotores dos seus genes alvo, denominadas de elementos responsivos aos proliferadores peroxissomais (PPREs). (Figura adaptada de Choi J-M, Bothwell ALM. The Nuclear Receptor PPARs as Important Regulators of T-Cell Functions and Autoimmune Diseases. Molecules and Cells. 2012; 33(3): 217-222 (35)). 
Os PPARs regulam a atividade transcricional por meio de três mecanismos: a repressão independente do ligante, a ativação transcricional e a transrepressão, sendo os dois últimos mecanismos dependentes de ligantes (32) (Figura 3).

A

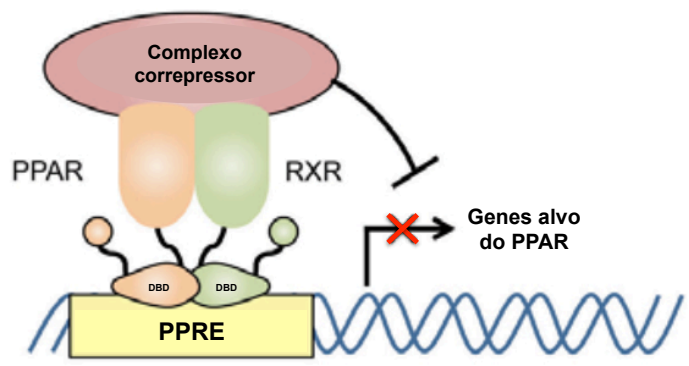

C

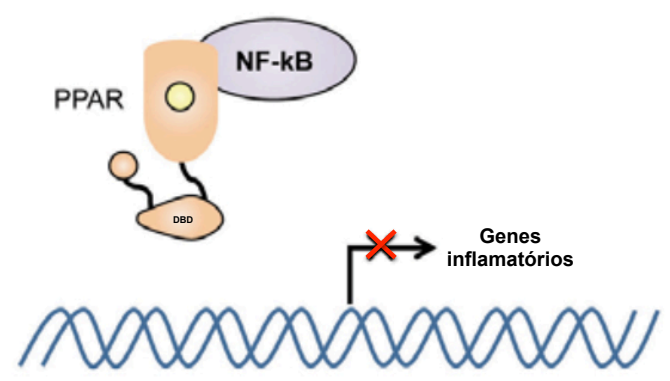

Ligante
B
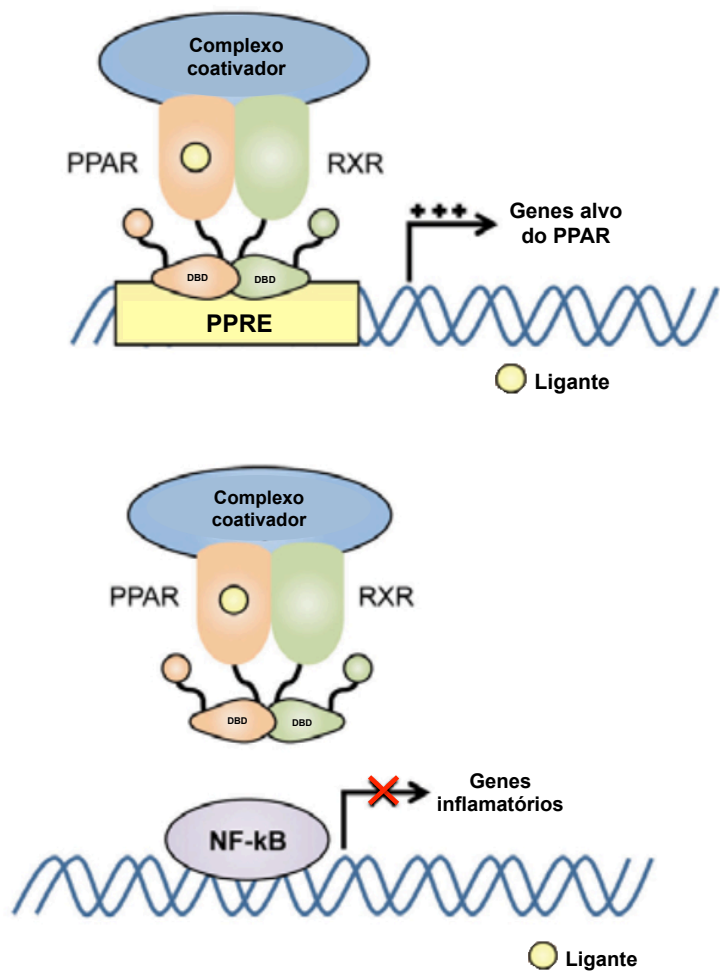

Figura 3. Mecanismos de controle da atividade transcricional pelos PPARs.

(A) Repressão independente do ligante: o heterodímero PPAR/RXR encontra-se no núcleo celular ligado constitutivamente aos PPREs em associação com um complexo correpressor, o que reprime a transcrição gênica. (B) Ativação transcricional dependente do ligante: a ligação de um agonista gera uma mudança conformacional que induz a liberação do complexo correpressor e a associação de proteínas coativadoras, que descompactam a cromatina, facilitando a ligação da maquinaria transcricional basal ao promotor dos genes alvo, promovendo a transcrição. (C) Transrepressão dependente do ligante: os PPARs podem suprimir a expressão de genes pró-inflamatórios por diferentes mecanismos, como por exemplo, ligando-se diretamente a outros fatores de transcrição (como o NF-kB) ou competindo com os mesmos pela ligação à proteínas coativadoras, o que mantêm os genes inflamatórios reprimidos. (Figura adaptada de Choi J-M, Bothwell ALM. The Nuclear Receptor PPARs as Important Regulators of T-Cell Functions and Autoimmune Diseases. Molecules and Cells. 2012; 33(3): 217-222 (35)).

$\mathrm{Na}$ ausência do ligante, o heterodímero PPAR/RXR encontra-se no núcleo celular ligado constitutivamente aos PPREs em associação com um complexo correpressor, o que reprime a transcrição gênica. Esse complexo é formado por proteínas correpressoras, como por exemplo o NCoR (correpressor do receptor nuclear - nuclear receptor corepressor) e o SMRT (mediador do silenciamento dos receptores retinóide e do hormônio tireoidiano - silencing mediator for retinoid and 
thyroid hormone receptors) e também pelas HADCs (histonas deacetilases - histone deacetylases), enzimas que mantém a cromatina compactada, impedindo que ocorra a transcrição (51).

O seu mecanismo clássico de ação, denominado de ativação transcricional ou transativação, é dependente do ligante e a resposta consiste em um aumento da expressão dos genes regulados positivamente por estes receptores (40). Neste tipo de regulação, a ligação de agonistas ao PPAR gera a movimentação da H12, que se fecha e faz com que o LBD adquira uma estrutura mais compacta e rígida. Essa mudança conformacional, induz a liberação do complexo correpressor e cria, na superfície do receptor, uma região hidrofóbica que possui alta afinidade com proteínas coativadoras $(6,51,52)$. Os coativadores, como por exemplo os da família de proteínas p160/SRC e os p300/CBP, atuam modificando a estrutura da cromatina, através de suas atividades como histona acetiltransferases ou recrutando estas enzimas, deixando-a menos compacta e permitindo assim que ocorra a transcrição (53). Esta atividade permite aos PPARs regularem positivamente os genes envolvidos no controle do metabolismo lipídico e da homeostase da glicose (54).

Os PPARs também podem regular negativamente a expressão gênica de maneira dependente do ligante, por meio da transrepressão, que é a forma pela qual estes receptores inibem a expressão de genes inflamatórios. Não há um mecanismo único que explique este tipo de regulação, mas sim, vários, e que podem se diferenciar dependendo da isoforma de PPAR e também do tipo celular estudado (54). Ao contrário da repressão e da transativação, a transrepressão não envolve a ligação dos PPARs aos seus PPREs (51). A seguir, há alguns exemplos deste tipo de regulação da expressão gênica.

Estudos sugerem que os PPARs suprimem a expressão de genes próinflamatórios ligando-se diretamente a outros fatores de transcrição (54). O trabalho de Delerive e colaboradores mostrou que, por meio de interações proteína-proteína, o PPARa se liga ao NF-kB (fator nuclear kappa B - factor nuclear kappa B) e à AP-1 (proteína ativadora 1 - activating protein-1) impedindo a ligação dos mesmos aos seus genes alvos, como por exemplo a IL-6 (interleucina 6 - interleukin 6) (55).

Os PPARs também podem reprimir genes inflamatórios competindo com outros fatores de transcrição pela ligação com proteínas coativadoras (54). O PPARy, por exemplo, compete com o NF-kB e a AP-1 pelos coativadores CBP/p300 
e SRC-1, o que impossibilita a ligação dos mesmos aos promotores dos seus genes alvos, tal como o iNOS (óxido nítrico sintase induzível - inducible nitric oxide synthase), reprimindo desta forma a sua transcrição (56).

A transrepressão também pode ocorrer por meio de uma modificação póstraducional que envolve a ligação da proteína SUMO (small ubiquitin-like modifier) aos PPARs. Em condições basais, o complexo correpressor NCoR inibe a transcrição dos genes iNOS e TNFa e, na presença de um sinal inflamatório, este complexo é removido com consequente transcrição destes genes. No entanto, a SUMOilação do PPARy dependente de ligante, faz com que este receptor se ligue a este complexo impedindo que o mesmo seja ubiquitinado. Como resultado, o complexo NCoR não se desliga dos promotores iNOS e TNFa, mantendo assim os genes reprimidos $(57,58)$.

2.1.1.1 Receptores Ativados por Proliferadores Peroxissomais do Tipo Gama

Nos seres humanos, o gene PPARG está localizado no cromossomo 3 na posição 3p25 e é transcrito em quatro diferentes tipos de RNA mensageiros (mRNA) que são o - $\gamma 1,-\gamma 2$, - $\gamma 3$ e - -4 , cada um originário de um promotor diferente. Já em camundongos, apenas dois subtipos de mRNA foram detectados, $-\gamma 1$ e $-\gamma 2$. Apesar de existirem quatro subtipos de mRNA, em humanos o PPARy é expresso de duas formas, como PPARy1 e PPARy2, em um processo resultante do uso de diferentes promotores e splicing alternativo. Os mRNAs dos PPARY1, - $\gamma 3$ e - $\gamma 4$ dão origem à mesma proteína, o PPARy1 (que possui 477 aminoácidos), enquanto que o mRNA do PPARy2 codifica a proteína PPARy2, que possui 30 aminoácidos adicionais localizados na porção amino terminal (59).

O PPARy1 possui uma expressão tecidual mais ampla e pode ser encontrado em baixos níveis no cérebro, em células epiteliais intestinais e vasculares, em adipócitos, macrófagos e em células musculares cardíacas e esqueléticas. Já o PPARy2 é expresso de forma seletiva e em altos níveis nos tecidos adiposos branco e marrom (40). 
Já foram identificados diversos ligantes de PPARy e entre os ligantes naturais encontram-se os ácidos graxos poliinsaturados e seus derivados (eicosanóides) (60), a prostaglandina J2 (15-Deoxy-Delta-12,14-prostaglandin J2 - 15d-PGJ2) (61) e as lipoproteínas oxidadas de baixa densidade (oxoLDL) (62). Os ligantes sintéticos incluem as tiazolidinadionas (TZDs), que possuem alta afinidade pelo PPARy, como por exemplo a rosiglitazona, a pioglitazona e a troglitazona, que já foram bastante utilizadas clinicamente como drogas sensibilizadoras de insulina em pacientes com diabetes mellitus tipo 2 (63-65).

Uma característica comum a alguns destes ligantes é o fato deles se ligarem ao PPARy por meio de uma ligação covalente com a cisteína 285 , que fica localizada na H3 do LBD do receptor. Alguns exemplos são os ligantes naturais prostaglandina J2 e os ácidos eicosatetraenóicos oxidados (oxoETEs) (66). Inclusive, resultados de estudos mostram que mutações nesse aminoácido praticamente suprimem a ativação do PPARY por alguns ácidos graxos de ocorrência natural (66-68).

Também já se encontra relatado na literatura que certos ligantes sintéticos se ligam à cisteína 285. Leesnitzer e colaboradores mostraram que o GW9662, um antagonista específico do PPARy, realiza uma ligação covalente com este resíduo (69). Além deste ligante, resultados de um estudo realizado por pesquisadores do nosso grupo de pesquisa indicaram que o GQ-16, um agonista parcial específico de PPARy, também interage diretamente com esta cisteína (70). E, mais recentemente, Harada e colaboradores demonstraram, por meio de estrutura cristalográfica, que o poluente ambiental cloreto de tributilestanho se liga ao LBD do PPARy por meio da interação com este aminoácido (71).

Esses resultados indicam que a ligação a esse resíduo parece ser essencial para a ativação do PPARY por estes ligantes (66).

\subsection{PPARY e Adipogênese}

O PPARY é considerado o regulador chave da adipogênese $(72,73)$ e promove a diferenciação de adipócitos juntamente com outros fatores de transcrição 
denominados de proteínas C/EBPs (proteínas de ligação ao amplificador CCAAT CCAAT-enhancer-binding proteins) $(65,74)$.

$\mathrm{Na}$ presença de estímulos adipogênicos tais como insulina e glicocorticóides, observa-se no início da diferenciação, um aumento rápido e transitório na expressão de C/EBPß e C/EBPס $(75,76)$. Esta cascata transcricional induz a expressão, quase que simultaneamente, do PPARy e do C/EBPa (74), que são os responsáveis por promover a expressão de vários genes, tais como: (i) genes que caracterizam o fenótipo de adipócito maduro (77), como FAT/CD36 (translocase de ácido graxo CD36 - fatty acid translocase CD36) (78), a Fabp4 (proteína ligadora de ácido graxo 4 - fatty acid binding protein 4) que foi identificada inicialmente como proteína 422 (79) e a perilipina, uma proteína que recobre a superfície das gotículas de gordura (80); (ii) genes relacionados com o metabolismo lipídico, tais como a ácido graxo sintetase (81), a estearoil-CoA-desaturase e a acil-CoA-sintetase (82) e (iii) genes relacionados com o aumento da sensibilidade à insulina, como o Glut4 (transportador de glicose tipo 4 - glucose transporter type 4), promovendo também o aumento no número de receptores de insulina $(83,84)$.

A importância do PPARy e do o C/EBPa nesse processo de diferenciação de adipócitos pode ser constatada a partir dos resultados de estudos mostrando que a expressão ectópica do PPARY é capaz de induzir a diferenciação em adipócitos de células não comprometidas com a diferenciação adipocitária, como por exemplo os fibroblastos NIH-3T3 (73) e até mesmo a transdiferenciação de mioblastos em adipócitos (85). De modo bem semelhante, a expressão ectópica de C/EBPa em pré-adipócitos também promove a adipogênese. Contudo, trabalhos sugerem que o PPARy seja o principal regulador deste processo, já que fibroblastos que não expressam este receptor são incapazes de se diferenciarem em adipócitos, mesmo quando o C/EBPa é acrescentado em níveis elevados (65).

Os estudos in vivo também ilustram bem o papel deste receptor na adipogênese. Em camundongos, a mutação do PPARY em homozigose é incompatível com a vida, levando os embriões à morte bem no início da gestação (aproximadamente 10 dias) (86). Já em humanos, mutações heterozigotas não dominantes no gene PPARG estão associadas a lipodistrofias $(87,88)$. 


\subsection{PPARy, Resistência à Insulina e Inflamação}

Além da expressão dos genes que caracterizam o fenótipo de adipócitos, assim como daqueles que participam do metabolismo lipídico, os adipócitos também sintetizam e secretam uma série de outras moléculas, que em conjunto são denominadas de adipocinas $(89,90)$.

Durante muito tempo o tecido adiposo foi visto apenas como um reservatório passivo de gordura $(89,90)$. Os primeiros relatos sobre a existência de adipocinas são da década de 1980, quando Cook e colaboradores encontraram no plasma sanguíneo uma proteína originária de adipócitos, que foi designada como adipsina, que está diretamente relacionada à obesidade (91). Entretanto, foi a partir de 1994, com a identificação da leptina (92), que o tecido adiposo passou a ser reconhecido como um órgão endócrino metabolicamente ativo (90). A partir daí, já foram descobertas cerca de 50 adipocinas (93), como a adiponectina (94), que age aumentando a sensibilidade à insulina (95) e a resistina, cuja secreção influencia negativamente a ação deste hormônio (96).

Muitas destas adipocinas são citocinas pró-inflamatórias que agem tanto localmente (ação autócrina/parácrina), quanto sistemicamente (ação endócrina), contribuindo para o desenvolvimento de uma série de fisiopatologias, como a resistência à insulina e a inflamação, condições que estão diretamente associadas com a obesidade $(89,93)$.

A obesidade contribui para essas desordens metabólicas pelo fato da hipertrofia dos adipócitos causar intensa secreção de citocinas pró-inflamatórias por esse tipo celular, como o TNFa (fator de necrose tumoral alfa - tumor necrosis factor alpha) (97) e a IL-6 (98). O principal efeito dessas citocinas é diminuir a captação de glicose pelas células, pois provocam a redução da fosforilação do IRS1 (substrato 1 do receptor de insulina - insulin receptor substrate 1) e também da expressão e da translocação do Glut4 do citoplasma para a membrana celular $(99,100)$. Desta forma, à medida que o tecido adiposo aumenta, particularmente o tecido adiposo visceral, mais comprometida fica a ação da insulina nesse compartimento, levando a um quadro sistêmico de inflamação e resistência insulínica (89). O tecido adiposo visceral está mais relacionado ao desenvolvimento da sensibilidade à insulina pelo fato de secretar uma maior quantidade de citocinas pró-inflamatórias em 
comparação ao depósito subcutâneo (98).

Já se encontra bem relatado na literatura que a ativação do PPARY está associada à melhora da resistência à insulina e inflamação. No entanto, ainda não se encontram totalmente esclarecidos como essas respostas são desencadeadas e há evidências de que não apenas um, mas vários mecanismos estejam envolvidos (64). A resistência à insulina é definida como a incapacidade das células ou tecidos de responderem aos níveis fisiológicos de insulina, sendo uma condição característica do diabetes mellitus tipo 2 (101).

Resultados de estudos in vitro mostraram que a ativação de PPARY pela ciglitazona aumentou a expressão do Glut4, um transportador de glicose estimulado pela insulina, o que reduziu a glicemia (83). Além disso, em modelos animais foi observado que a rosiglitazona aumentou a captação de ácidos graxos pelo tecido adiposo e diminuiu a captação destes pelo fígado e músculo esquelético, estes dois últimos, tecidos mais sensíveis à ação da insulina (102).

Um outro possível efeito decorrente da ativação do PPARy está relacionado à capacidade das TZDs em estimular a formação de adipócitos de diâmetros menores. Ratos obesos foram tratados com troglitazona durante 15 dias e, apesar de não terem apresentado mudanças no peso total do tecido adiposo branco após esse período, foi possível observar um aumento no número de adipócitos pequenos (< $2500 \mu \mathrm{m}^{2}$ ), mais sensíveis à insulina, bem como uma indução da apoptose dos adipócitos maiores (> $5000 \mu \mathrm{m}^{2}$ ), que são mais resistentes à sua ação. Esta TZD também normalizou os níveis de TNFa, que eram cerca de duas vezes maiores nos ratos obesos em relação aos controles (103).

Observa-se também que as TZDs causam uma alteração no perfil de adipocinas secretadas pelo tecido adiposo (104). O tratamento com estes agonistas de PPARY promove um aumento na secreção de adiponectina (95) e redução dos níveis de resistina (96), promovendo a melhora da resistência à insulina.

Resultados de estudos com humanos também ajudam a explicar o aumento da sensibilidade à insulina decorrente da ativação do PPARy. Pacientes com diabetes mellitus tipo 2 tratados com troglitazona apresentaram aumento do tecido adiposo subcutâneo com consequente redução ou manutenção do tecido adiposo visceral $(105,106)$. Estes resultados indicam que a melhora da resistência à insulina pode estar associada a esta redistribuição da gordura em diferentes depósitos de tecido adiposo, o que favoreceria a ação da insulina no tecido subcutâneo, 
compartimento menos resistente à sua ação (107).

Uma outra possibilidade relatada é que modificações pós-traducionais deste receptor podem contribuir para a redução da resistência à insulina. Choi e colaboradores observaram que as TZDs e outros agonistas parciais agem inibindo a fosforilação da serina 273 do PPARy pela Cdk5 (ciclina dependente de quinase 5 cyclin-dependent kinase 5), uma quinase que pode ser ativada por várias citocinas pró-inflamatórias. A fosforilação deste aminoácido causa a diminuição da expressão da adiponectina, uma adipocina cujas concentrações plasmáticas estão diretamente relacionadas com o aumento da sensibilidade à insulina. Tanto em animais como em humanos, a melhora da sensibilidade à insulina também estava relacionada com a diminuição da fosforilação do PPARy via Cdk5 (108).

Além do tecido adiposo, o PPARy também é expresso em células da parede vascular, como macrófagos, células endoteliais e células musculares lisas (36). Há várias evidências de que a ativação deste receptor pelas TZDs pode ser benéfica para pacientes com aterosclerose, uma doença crônica caracterizada pelo acúmulo de lipídios e tecido conjuntivo fibroso nas grandes artérias, acompanhada por uma resposta inflamatória local (109).

A ativação deste receptor inibe a proliferação e a migração de células do músculo liso vascular e suprime a expressão de citocinas pró-inflamatórias nos macrófagos, tais como IL-6, IL-1 $1 \beta$ e TNFa $(110,111)$. A atividade anti-aterogênica desencadeada pela ativação do PPARy também inclui a indução da expressão de proteínas envolvidas no transporte reverso de colesterol (109).

Diante de tudo o que foi exposto, não é surpreendente que drogas antihiperglicemiantes tenham como alvo o PPARy. As TZDs, agonistas sintéticos deste receptor, são exemplos de fármacos utilizados no controle do diabetes mellitus tipo 2 $(112,113)$. Entretanto, o uso da rosiglitazona foi suspenso no Brasil (114) e na Europa (115), enquanto a pioglitazona teve seu uso proibido em vários países da Europa (116), em decorrência dos sérios efeitos adversos decorrentes do seu uso. Nos Estados Unidos, a partir de 2010, o uso da rosiglitazona passou a ser restrito. Contudo, o FDA (U. S. Food and Drug Administration) removeu estas restrições no final de 2013, garantindo que os benefícios do medicamento compensavam os seus riscos. Esta medida foi tomada após a constatação de que não houve diferenças no risco de ataques cardíacos entre pacientes tratados com TZDs e outras drogas utilizadas no tratamento do diabetes mellitus tipo 2 , como a metformina e as 
sulfoniluréias (117).

Além do aumento do risco de infarto do miocárdio e de mortes por causas cardiovasculares (118), que levou à proibição do uso da rosiglitazona em alguns países, é também observada uma maior fragilidade esquelética em decorrência do seu uso (119).

Uma meta-análise que avaliou 42 estudos mostrou que pacientes diabéticos que faziam uso de rosiglitazona, tiveram um aumento no risco de infarto do miocárdio e também de morte por causas cardiovasculares (118). Estudos também demonstraram que a principal causa do aumento da mortalidade cardíaca em pacientes diabéticos tipo 2 que faziam uso de TZD é o fato destes fármacos aumentarem a retenção hídrica (47).

$\mathrm{Na}$ literatura também há diversos relatos sobre o maior risco de fraturas que pacientes com diabetes mellitus tipo 2 apresentam (120-123). Em um estudo observacional, mulheres diabéticas que faziam uso de troglitazona, pioglitazona ou rosiglitazona foram acompanhadas durante 4 anos e verificou-se que o uso destes fármacos estava associado a uma perda óssea significativa em diversos sítios esqueléticos (124). Como adipócitos e osteoblastos originam-se do mesmo tipo celular (células mesenquimais progenitoras da medula óssea), a ativação desta isoforma de PPAR pelas TZDs acaba favorecendo a diferenciação destas células em adipócitos ao invés de osteoblastos (células responsáveis pela produção da matriz óssea), o que explica esta fragilidade esquelética $(119,125,126)$. Outro dado interessante é que mesmo em mulheres não diabéticas, o uso de rosiglitazona por apenas 14 semanas também influenciou negativamente o equilíbrio do tecido esquelético, o que foi verificado por meio da diminuição dos níveis séricos de marcadores de atividade de osteoblastos (119).

Analisando estes resultados, ficam evidenciadas as implicações negativas que a ativação do PPARy causa no sistema cardiovascular e na integridade óssea, apesar dos efeitos benéficos de regulação da glicemia, da sensibilidade insulínica, do metabolismo lipídico e da inflamação. Devido a isso, é crescente o interesse por se desenvolver fármacos que ativem parcialmente o PPARY, na tentativa de não "superativar" este receptor e obter-se as ações benéficas com o mínimo de efeitos adversos $(70,108,127,128)$. 


\subsection{DESREGULADORES ENDÓCRINOS}

O ambiente químico ao qual os seres humanos estão expostos vem mudando de forma significativa. Após a Segunda Guerra Mundial, com o crescimento econômico e industrial, numerosos compostos vêm sendo produzidos e liberados no meio ambiente em larga escala $(1,3)$. Consequentemente, os seres humanos estão a todo momento em contato com vários desses produtos químicos, tais como pesticidas, corantes, pigmentos, medicamentos, aromas, perfumes, plásticos, resinas, borrachas dentre outros $(3,9)$. Com todas essas fontes de exposição, há também uma crescente preocupação em relação aos efeitos destes compostos tanto no meio ambiente, quanto nos animais que nele vivem, incluindo os seres humanos (1).

Muitos desses produtos são classificados como poluentes orgânicos persistentes (Persistent Organic Pollutant, POPs) que, por definição, são substâncias que persistem no meio ambiente, apresentando meia vida de anos ou décadas no solo e nos sedimentos e de vários dias na atmosfera (129). De uma forma geral, os POPs também são lipofílicos, hidrofóbicos, quimicamente estáveis e apresentam potencial de bioacumulação, ou seja, se movimentam ao longo das cadeias alimentares. Devido a todas essas propriedades, mesmo que os efeitos de vários POPs sobre o funcionamento de sistemas biológicos ainda sejam desconhecidos, são considerados potenciais fontes causadoras de danos aos seres vivos $(4,129)$.

Outro aspecto preocupante é que também há evidências de que várias destas substâncias interferem no funcionamento do sistema endócrino, atuando como desreguladores endócrinos (DEs) (3). Os DEs são agentes exógenos que interferem na síntese, secreção, transporte, metabolismo, ligação ou eliminação de hormônios naturais presentes no organismo, que são responsáveis pela manutenção da homeostase, pela reprodução e pelo processo de desenvolvimento (130).

O grupo de moléculas identificadas como DEs é bastante heterogêneo e inclui tanto compostos naturais como sintéticos (5). Os fitoestrógenos, compostos com atividade estrogênica mais fraca que a dos estrogênios endógenos, são exemplos de DEs naturais. Eles podem ser encontrados em diversos alimentos, tais como grãos, alguns fungos, ervas, gramíneas, leguminosas e frutas. Já os DEs sintéticos 
são compostos orgânicos, de origem antropogênica, ou seja, que são encontrados no meio ambiente em decorrência de atividades humanas, sintetizados a partir do carbono e de outros elementos, como o hidrogênio, o nitrogênio e o cloro (131). Para exemplificar, podem ser citados os bifenilos policlorados (PCBs) e as dioxinas (usados na indústria como solventes e lubrificantes); os retardadores de chama polibromados (como os éteres difenílicos polibromados - PBDEs e os bifenilos polibromados - PBBs, que ajudam a retardar ou impedir a combustão); o bisfenol A (BPA) e os ftalatos (ambos utilizados na fabricação de plásticos); os organofosforados (como o dicloro-difenil-tricloroetano, DDT, usado como pesticida); a vinclozolina (fungicida), o dietilestilbestrol (fármaco), os metais pesados (como o cádmio e o chumbo) e alguns produtos de uso doméstico incluindo produtos de limpeza, purificadores de ar, tintas para cabelo, cosméticos e protetores solares (5, 131-133).

Os seres humanos podem entrar em contato com os DEs de várias formas, seja por meio da sua ocupação, da ingestão de água e alimentos e pelo contato com o meio ambiente (água, solo e ar) (133).

Esses compostos podem exercer suas ações desreguladoras endócrinas via receptores de hormônios esteróides não nucleares (como os receptores de estrógeno de membrana), receptores não esteróides (por exemplo, os receptores de neurotransmissores tais como os receptores de serotonina, de dopamina e de noradrenalina) e receptores órfãos (como o receptor de hidrocarboneto de arila). Os DEs também desencadeiam seus efeitos através de vias enzimáticas envolvidas na biossíntese e/ou metabolismo de esteróides e por meio de numerosos outros mecanismos que convergem para os sistemas endócrino e reprodutivo $(5,131)$.

Embora os DEs tenham uma estrutura química bastante variada, eles possuem algumas características que são comuns aos ligantes de receptores nucleares, como pequena massa molecular (geralmente inferior a 1000 Daltons) (5) e natureza lipofílica (3). Devido a isso, não é surpreendente que muitos DEs também atuem via membros da superfamília de receptores nucleares, tais como PR, GR,

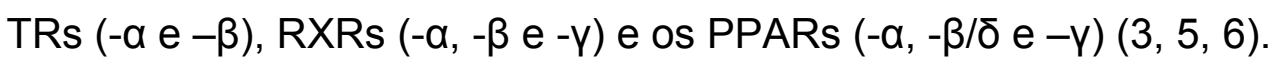

Há vários trabalhos mostrando os efeitos dos DEs sobre o funcionamento de sistemas biológicos e dados epidemiológicos mostram um aumento na incidência e na prevalência de várias doenças (como por exemplo o câncer de mama, de próstata e de testículo, o diabetes, a obesidade e a diminuição da fertilidade) devido 
à exposição a estes compostos (132). Um dos primeiros compostos sintéticos considerado como DE foi o dietilestilbestrol (DES), o primeiro estrogênio artificial desenvolvido. Este fármaco foi bastante utilizado entre as décadas de 1940 e 1960 por mulheres grávidas, pois acreditava-se que o seu uso estava associado à redução do risco de aborto espontâneo. Os resultados mostraram que as mulheres gestantes que utilizaram o DES apresentaram um maior risco de desenvolvimento de câncer de mama ao longo de suas vidas. Já as filhas que tiveram contato com este fármaco no período intra-uterino tiveram redução da fertilidade e risco aumentado de câncer cervical. Enquanto que os filhos expostos durante a gestação exibiram um maior risco de câncer de testículos e aumento da prevalência de anomalias urogenitais (134).

Outra substância química cuja a atividade desreguladora endócrina encontrase bem caracterizada é o BPA, utilizado na fabricação de materiais plásticos e resinas, podendo ser encontrado em vários recipientes de alimentos e bebidas, assim como em moldes dentários. A exposição ao BPA está associada à redução da fertilidade e também ao maior risco de desenvolvimento de câncer de mama e de próstata (135). Além disso, em cultura de células, observou-se que o BPA induziu a diferenciação de fibroblastos 3T3-L1 em adipócitos (136). Este efeito adipogênico do BPA também já foi observado in vivo, tanto em animais (137) quanto em humanos (138). Ratos fêmeas grávidas expostas ao BPA, via água de beber, deram origem a descendentes com maior peso corporal após o nascimento, consequência que perdurou até a vida adulta (137). Já em crianças chinesas, foi observada uma relação dose-resposta entre os níveis de BPA na urina e o aumento do risco de sobrepeso (138).

Os ftalatos também são DEs aos quais os seres humanos estão constantemente expostos. São utilizados no processo de fabricação de materiais plásticos derivados do policloreto de polivinila (polyvinyl chloride - PVC), sendo considerados tóxicos para a reprodução e para o desenvolvimento (139). Há também um estudo mostrando que, em homens adultos norte americanos, 0 aumento nas concentrações de metabólitos do ftalato na urina estão diretamente associados ao aumento da circunferência da cintura e da resistência à insulina (140).

Uma característica de vários DEs que vem chamando bastante atenção é o fato destes compostos também possuírem potencial "obesogênico". Esse termo foi 
utilizado pela primeira vez em 2006, pelos pesquisadores Grun e Blumberg, e se refere a produtos químicos (naturais, farmacêuticos ou xenobióticos) que promovem a obesidade, seja aumentando o número de adipócitos ou o armazenamento de gordura em células já existentes $(7,8)$.

A obesidade é definida como o acúmulo anormal ou excessivo de gordura corporal, que apresenta risco para a saúde. Segundo dados da Organização Mundial da Saúde (World Health Organization - WHO), em 2014, mais de 1,9 bilhões de adultos (indivíduos com idade igual ou superior a 18 anos), o que corresponde a $39 \%$ da população mundial, estavam acima do peso. Deste total, mais de 600 milhões eram considerados obesos (13\% da população mundial) (141). A prevalência da obesidade mais do que duplicou entre 1980 e 2014 (141) e continua crescendo em um ritmo acelerado, tanto nos países desenvolvidos quanto nos em desenvolvimento $(142,143)$. É uma doença com etiologia multifatorial que envolve fatores genéticos, nutricionais, psicológicos, ambientais e sociais $(144,145)$ e considerada um grave problema de saúde pública, não somente pela epidemia que se tornou nos últimos anos, como também pelo fato de predispor o desenvolvimento de uma série de doenças, como hipertensão arterial sistêmica, dislipidemia, diabetes mellitus tipo 2 e alguns tipos de neoplasias malignas (141).

Um aspecto preocupante é o fato de também ter se tornado um sério problema de saúde para crianças e adolescentes (população com idade inferior a 18 anos). A estimativa da Organização Mundial da Saúde é de que, em 2014, cerca de 41 milhões de crianças com menos de 5 anos estavam com sobrepeso ou obesidade. Crianças obesas e com sobrepeso são mais susceptíveis a permanecer obesos na idade adulta e também mais propensos a desenvolver, em idade mais jovem, doenças cardiovasculares e diabetes mellitus tipo 2 (141).

Estudos recentes têm mostrado que além dos fatores já bem conhecidos como dieta, inatividade física e genética, o ambiente ao qual os seres humanos estão expostos também estão implicados no desenvolvimento da obesidade $(2,9$, 132).

Em 2002, Paula Baillie-Hamilton foi uma das primeiras a relatar que, juntamente com vários outros fatores, existe uma associação entre o aumento da concentração de certas substâncias químicas no ambiente e o aumento da incidência da obesidade (9). Além disso, ao contrário da perda de peso que ocorre devido ao contato com elevadas concentrações de muitos produtos químicos, este 
ganho de peso tende a ocorrer em níveis muito mais baixos de exposição $(5,9)$.

Essa correlação postulada por Paula Baillie-Hamilton tem o suporte de diversos estudos que vêm mostrando que uma série de compostos químicos são capazes de induzir a adipogênese e contribuir para o desenvolvimento da obesidade, da dislipidemia, da resistência à insulina e do diabetes mellitus tipo 2 (2, 132, 133). Alonso-Magdalena e colaboradores mostraram que camundongos fêmeas tratados com BPA durante a gestação (administrado por via subcutânea) apresentaram diminuição da tolerância à glicose e aumento nas concentrações plasmáticas de insulina, de leptina e de triglicerídeos. Estes efeitos também foram observados nos descendentes que tiveram contato com o BPA in utero (10). Em outro estudo, ratos foram expostos a diversos POPs lipofílicos, por meio da dieta, e os resultados mostraram que estes animais desenvolveram resistência à insulina e esteatose hepática, apresentando também aumento da massa do tecido adiposo visceral (11). Em humanos, já foi demonstrado haver uma associação dosedependente entre as concentrações séricas de PBBs, PBDEs (12) e de organoclorados (13) com a prevalência de diabetes e síndrome metabólica. Kim e colaboradores também mostraram que a concentração corporal total de alguns POPs com ação DE, como as dioxinas e os bifenilos policlorados, é cerca de 2 a 3 vezes maior em indivíduos obesos em comparação aos controles magros. Além disso, os pacientes obesos apresentam maiores concentrações destes DEs/POPs tanto no plasma como nos tecidos adiposos subcutâneo e visceral, não havendo diferenças entre estes dois compartimentos. Inclusive, quando esses mesmos indivíduos obesos eram submetidos à cirurgia bariátrica, dentro de 6 a 12 meses já era possível observar uma redução de cerca de $15 \%$ no conteúdo corporal total destes DEs/POPs (146). Em conjunto, todos esses resultados mostram que o tecido adiposo é alvo de muitos DEs, desempenhando um importante papel na cinética, na toxicidade e no desencadeamento dos efeitos dos DEs in vivo.

Sem dúvida alguma, esta "revolução química sintética" proporcionou grandes melhorias para a qualidade de vida dos seres humanos. No entanto, há cada vez mais evidências de que esses benefícios vieram agregados a um custo oculto (2), sendo necessários mais pesquisas com o intuito de se compreender melhor o mecanismo de ação destes compostos DEs.

Um dos obesogênicos ambientais mais estudados é o cloreto de tributilestanho (15). Além deste composto, há o dibutilestanho, que apesar de ainda 
não ter sido muito explorado do ponto de vista científico, é amplamente utilizado para diversas finalidades. A seguir, encontra-se uma revisão de literatura sobre estes dois organoestânicos.

\subsubsection{Organoestânicos}

Os organoestânicos compreendem um grupo de moléculas organo-metálicas caracterizadas pela presença de um átomo de estanho (Sn) ligado covalentemente a um ou mais grupamentos orgânicos (24). Mais de 800 tipos de organoestânicos já foram identificados, sendo que a maioria deles possui origem antropogênica (24).

Estes compostos são representados pela fórmula química geral $R_{n} S_{n} X_{4-n}$, na qual R é um grupamento orgânico, podendo ser um grupo alquila (exemplos: metil, etil, propil ou butil) ou um grupo arila (exemplo: fenil) e $X$ é uma espécie aniônica (exemplos: haleto, óxido ou hidróxido) (24). Dependendo da quantidade de grupos $\mathrm{R}$ ligados ao átomo de $\mathrm{Sn}$, são classificados como mono-, di- ou tri-, seguido pelo

nome do grupamento orgânico, como por exemplo, trifenilestanho. Quando o grupamento orgânico não é identificado, são genericamente denominados de mono-, di- ou tri-substituídos. Os compostos tetra-substituídos são utilizados apenas como precursores na síntese de outros organoestânicos (147).

Apresentam ligações Sn-C (estanho-carbono) altamente estáveis, mesmo em temperatura próximas a $200^{\circ} \mathrm{C}$, e também na presença do oxigênio e da água (24), a hidrólise praticamente não ocorre (16). Em geral, são lipofílicos e hidrofóbicos (147). A solubilidade em água depende da natureza da espécie aniônica (representada pelo $\mathrm{X}$ na fórmula química $\mathrm{R}_{n} \mathrm{SnX}_{4-n}$ ) e diminui com o aumento do número e do comprimento dos substitutos orgânicos. A sua degradação no meio ambiente, que envolve a remoção dos grupamentos orgânicos ligados ao átomo de estanho, pode ocorrer por meio de três processos: (i) exposição à radiação UV, (ii) clivagem química (por ácidos fortes e agentes eletrofílicos) e (iii) clivagem biológica (por alguns poucos microrganismos, como bactérias e algas) (24). Na água, a meia-vida destes compostos pode variar de dias até meses, com a degradação podendo ser muito mais lenta nos sedimentos, particularmente em condições anaeróbias, com persistência estimada de décadas (148). Todas essas características fazem com 
que sejam classificados como POPs (129).

O estanho na sua forma inorgânica é considerado atóxico, porém os seus derivados orgânicos apresentam toxicidade (24). Quanto maior a quantidade de grupos orgânicos ligados ao átomo de estanho, mais tóxico é o composto, com toxicidade máxima sendo observada para os compostos trialquilados. Já o aumento do comprimento da parte orgânica está diretamente relacionada com a diminuição da toxicidade destes compostos (16). O acetato de trietilestanho ( $\left.E_{3} S n O A c\right)$ é considerado o organoestânico mais tóxico para os mamíferos, enquanto os derivados de octilestanho são praticamente atóxicos para os seres vivos. A natureza da espécie aniônica exerce pouca ou nenhuma influência sobre a sua atividade biocida (24).

Os primeiros registros de uso dos organoestânicos para fins comerciais são de 1936, quando a indústria de materiais plásticos começou a utilizá-los como estabilizadores térmicos de polímeros sintéticos (16). Sob a influência da luz e do calor, ocorria fragilização e descoloração destes materiais e este desgaste passou a ser prevenido com o uso de organoestânicos no seu processo de fabricação (149).

Contudo, foi a descoberta das suas propriedades biocidas nos anos 1950 que ampliou a variedade de aplicações e impulsionou a produção desses compostos (150). A partir de 1960 passaram a ser utilizados em vários processos industriais e na agricultura e, nas décadas de 1970 e 1980, foram muito usados como pintura anti-incrustante. Entretanto, devido aos impactos ambientais negativos, seu uso para este propósito foi proibido (16).

Atualmente, o principal uso dos organoestânicos é como estabilizador na fabricação do PVC. Também são usados como biocidas, o que inclui a sua utilização na agricultura e na preservação de diversos produtos como madeiras, tecidos, papéis, couros e vidros. Além dessas finalidades, também atuam como catalisadores em diversos processos industriais $(16,24,27)$.

Todas essas aplicações fazem com que estes compostos sejam introduzidos diretamente no solo, ar e água tornando inevitável a exposição dos seres humanos e, consequentemente, aumentando a preocupação devido a toxicidade de vários deles (16).

Como já foram bastante utilizados como pintura anti-incrustante, esses organoestânicos eram liberados diretamente no meio aquático, podendo ser detectados em várias espécies de peixes, moluscos e crustáceos $(147,151)$. Ao 
consumir peixes, frutos do mar e derivados, os seres humanos poderiam ser contaminados (147). Atualmente, continuam sendo utilizados como biocidas (na agricultura e na preservação de produtos) e também na fabricação de polímeros plásticos. Devido a isso, podem ser absorvidos por inalação (de pesticidas, por exemplo) ou pelo contato direto com a pele (usando tecidos nos quais esses compostos foram utilizados como conservantes). A exposição também pode ocorrer por meio do consumo de água e alimentos contaminados, como por exemplo, ingestão de água distribuída por encanamentos fabricados com PVC e consumo de alimentos envolvidos por embalagens plásticas (147).

Não existem estudos epidemiológicos sobre a exposição crônica a baixos níveis de organoestânicos. Há, no entanto, alguns poucos relatos de casos que descrevem os efeitos da exposição aguda a estes compostos sobre a saúde humana (147). Em 1954, por exemplo, ocorreu na França um envenenamento generalizado devido ao uso, por via oral, de um medicamento utilizado no tratamento de infecções de pele por estafilococos. A formulação continha di-iodeto de dietilestanho e ácido linoleico e presume-se que também havia quantidades substanciais de iodeto de trietilestanho (como impureza), que é altamente tóxico. Esse episódio ocasionou em 100 mortes e em mais de 200 pessoas intoxicadas (152).

Devido a isso, a maioria das informações relacionadas às vias de absorção, distribuição, metabolismo e excreção dos organoestânicos foram obtidas baseadas em estudos experimentais realizados com animais (147).

A absorção dos organoestânicos pode ocorrer através das vias respiratórias, da pele e da mucosa intestinal. De uma forma geral, os compostos com pequena cadeia alquila são mais facilmente absorvidos pelo intestino, enquanto os trialquilados entram mais facilmente no organismo através da pele. A distribuição nos tecidos ocorre rapidamente, em animais (ratos, coelhos e hamsters), as maiores concentrações foram detectadas no fígado (153). Em outros órgãos e tecidos (como por exemplo, cérebro e tecido adiposo) foram detectadas concentrações mais baixas, porém, com maior quantidade de organoestânicos não metabolizados (147). A metabolização ocorre no fígado e envolve uma progressiva hidroxialquilação dependente do citocromo P450 e também a desalquilação e a desarilação daqueles que são di- e tri-substituídos. A forma de excreção depende do tipo do composto, mas geralmente é pela urina, fezes e bile, já tendo sido detectada no leite materno 
de ovelhas $(147,153)$. A meia-vida destas substâncias também varia de acordo com o tipo de organoestânico, mas a maioria permanece durante vários dias nos tecidos (em ratos, variou de 5 até 40 dias). Há evidências de que a meia-vida destes compostos seja maior no cérebro do que em outros órgãos, já tendo sido identificado no cérebro 38 dias após uma administração única (153).

Há vários tipos de organoestânicos, sendo que neste estudo os interesses estão voltados para os derivados do butilestanho. Dentre estes, o cloreto de tributilestanho é o mais estudado, havendo poucos relatos sobre os dibutilestanho. A seguir encontra-se um apanhado sobre as pesquisas já realizadas com estes compostos.

\subsubsection{Tributilestanho}

O tributilestanho (TBT) é um organoestânico formado por um átomo de Sn ligado covalentemente a três grupamentos butil. Várias espécies aniônicas podem ser encontradas associadas a este composto, como por exemplo o cloreto, o benzoato e o iodeto (24). O cloreto de tributilestanho (tributyltin chloride) é o organoestânico mais abundante no meio ambiente (154) e também o mais estudado (15). A seguir, são apresentados a estrutura química, o peso molecular e a fórmula linear deste composto (155).

Peso molecular: $325,508 \mathrm{~g} / \mathrm{mol}$ Fórmula linear: $\mathrm{C}_{12} \mathrm{H}_{27} \mathrm{ClSn}$

Figura 4. Estrutura química, peso molecular e fórmula linear do cloreto de tributilestanho.

Fonte: PubChem Compound Database (155). 
O cloreto de TBT teve o seu uso difundido quando foram descobertas suas ações biocidas. Nas décadas de 1970 e 1980 passou então a ser amplamente utilizado como pintura anti-incrustante em barcos, navios, estaleiros e docas para evitar a ligação de organismos marinhos aos cascos dos mesmos (16). A incrustação de organismos marinhos (como algas e mexilhões) aos cascos das embarcações era e continua sendo um problema, já que pode reduzir a velocidade dos barcos, o que aumenta o consumo de combustíveis, e também resultar na introdução de espécies consideradas "invasoras" em ecossistemas aos quais elas não pertencem (18). Entretanto, nos anos de 1980 começaram a surgir as primeiras evidências de que o seu uso causava sérios impactos ambientais (16).

Maguire e colaboradores foram os primeiros a relatarem a presença deste composto na água e em sedimentos do Canadá, com as maiores concentrações sendo encontradas nas áreas de tráfego pesado de embarcações $(156,157)$.

Neste mesmo período, também foram publicados os primeiros trabalhos revelando o impacto negativo desse organoestânico nos ecossistemas aquáticos. Os resultados mostraram que o cloreto de TBT provocava a má formação de conchas de ostras da espécie Crassostrea gigas (158-160), sendo extremamente tóxico tanto para ostras adultas como larvas, o que interferia diretamente na reprodução desta espécie (158). Também foi identificado que a exposição crônica a este composto poderia causar retardo no crescimento de peixes da espécie Oncorhynchus mykiss (trutas) (157). Já nos anos de 1990, foram detectados resíduos de cloreto de TBT no tecido adiposo de oito espécies de mamíferos marinhos, incluindo focas (Phoca largh), baleias (Orcinus orca e Balaenoptera acutorostrata) e golfinhos (Delphinus delphis) (161).

Além desses efeitos, em diversas espécies de vida marinha, como, por exemplo, em moluscos fêmeas da espécie Nucella lapillus, a exposição ao cloreto de TBT causa um fenômeno denominado de imposex, que é a indução anormal de caracteres masculinos em fêmeas. Recebe este nome pelo fato do pênis, ducto deferente e túbulos seminíferos se imporem, ou se sobreporem, à genitália feminina (162-165). A exposição inicial a este organoestânico diminui a capacidade reprodutiva das fêmeas, enquanto a exposição prolongada pode causar infertilidade e até a morte $(164,166)$. Este fenômeno ocorre devido à ação desreguladora endócrina do cloreto de TBT, que age inibindo a aromatase, uma enzima do citocromo $\mathrm{P} 450$, que é necessária para a conversão de androgênios em estrogênios. 
A inibição da aromatase por este composto eleva os níveis de testosterona, o que promove o desenvolvimento de características masculinas (167).

Todos esses estudos contribuíram de maneira significativa para a adoção de padrões regulatórios relacionados ao uso do cloreto de TBT em tintas antiincrustantes (16). Desde os anos 1980, alguns países incluindo França, Reino Unido, Japão, Alemanha e Estados Unidos têm regulamentado ou banido o uso deste composto para esta finalidade $(16,18)$. Devido à magnitude do problema, em 1990, o Comitê de Proteção do Ambiente Marinho (Marine Environment Protection Committee, MEPC) iniciou um debate sobre a necessidade de regulamentação global (168). Finalmente, em 1999, a Organização Marítima Internacional (International Maritime Organization - IMO) proibiu o uso do cloreto de TBT em navios, barcos, docas e estaleiros de todo o mundo, com a sua aplicação devendo ser banida até $1^{\circ}$ de janeiro de 2003 e com proibição total da sua presença em cascos até $1^{\circ}$ de janeiro de $2008(17,18)$. Embora proibido em pinturas antiincrustantes, este organoestânico continua sendo utilizado como estabilizador na fabricação do PVC e também como catalisador em diversos processos industriais (19).

No Brasil, em 2007, entrou em vigor a portaria $n^{\circ} 76$ da Diretoria de Portos e Costas da Marinha do Brasil, que aprovou as normas da autoridade marítima para o controle de sistemas anti-incrustantes danosos em embarcações, proibindo o uso de derivados do estanho em pinturas de embarcações (NORMAM-23/DPC) (169). Há também uma regulamentação publicada pelo Conselho Nacional do Meio Ambiente (CONAMA) em 2005 (resolução $n^{\circ}$ 357, alterada pelas resoluções 410/2009 e 430/2011) que estabelece os níveis máximos de TBT permitido em águas no território brasileiro, sendo (170):

- 0,063 $\mu \mathrm{g} / \mathrm{L}$ nas águas doces destinadas ao abastecimento humano, à recreação de contato primário (como por exemplo: natação e mergulho) e à irrigação de hortaliças e frutas que são ingeridas cruas;

- 2,0 $\mathrm{\mu g} / \mathrm{L}$ nas águas doces destinadas ao consumo humano, à pesca amadora, à recreação de contato secundário (como por exemplo: iatismo), à irrigação de culturas arbóreas, cerealíferas e forrageiras e à dessedentação de animais;

- 0,01 $\mu \mathrm{g} / \mathrm{L}$ nas águas salinas destinadas à recreação de contato primário, à aquicultura e à atividade de pesca; 
- 0,37 $\mu \mathrm{g} / \mathrm{L}$ nas águas salinas destinadas à pesca amadora e à recreação de contato secundário;

- 0,01 $\mu \mathrm{g} / \mathrm{L}$ nas águas salobras destinadas ao abastecimento humano, à recreação de contato primário, à aquicultura e à atividade de pesca, à irrigação de hortaliças e frutas que são ingeridas cruas, à irrigação de parques, jardins, campos de esporte e lazer, com os quais o público possa vir a ter contato direto;

- 0,37 $\mu \mathrm{g} / \mathrm{L}$ nas águas salobras destinadas à pesca amadora e à recreação de contato secundário.

Contudo, o impacto dessas recomendações é questionável, uma vez que os efeitos do cloreto de TBT em espécies marinhas já foram demonstrados em concentrações bem menores. No estudo de Gibs e colaboradores, foram relatados o imposex e também infertilidade em moluscos fêmeas da espécie Nucella lapillus que viviam em águas com concentração de TBT entre 1 e 2 ng/L (171).

Essa ação desreguladora endócrina do cloreto de TBT via aromatase, além de ter levado à proibição do seu uso como pintura anti-incrustante, também motivou a realização de diversos outros estudos. A partir daí, passou-se a investigar outros possíveis alvos moleculares para elucidar se este organoestânico agia somente como inibidor enzimático ou se também exercia seus efeitos desreguladores endócrinos em nível transcricional (22).

Os primeiros trabalhos realizados com esta finalidade mostraram uma diminuição nos níveis de mRNA da enzima aromatase em células da granulosa de ovários humanos quando as mesmas eram tratadas com agonistas de PPARY (troglitazona), de RXR (LG100268) ou com o cloreto de TBT (172, 173). Além desse estudo, Nishikawa e colaboradores também demonstraram, em um ensaio de ligação in vitro, que este organoestânico se ligava com alta afinidade ao LBD do RXRa humano (hRXRa) (174).

Embora o cloreto de TBT seja estruturalmente bem diferente dos ligantes naturais e sintéticos de PPARy e RXRa (22), ele possui algumas características que o assemelha a ligantes de receptores nucleares, como pequena massa molecular (inferior a 1000 Daltons) (5) e natureza lipofilica (3). Além disso, os resultados destes últimos trabalhos mostraram efeitos semelhantes exercidos pelo cloreto de TBT e por ligantes de PPARY e RXR na expressão do mRNA da aromatase, bem como a alta afinidade deste composto ao LBD do RXRa humano. Essas evidências 
levantaram, então, a hipótese de que este organoestânico poderia exercer seus efeitos desreguladores endócrinos por meio da ativação de um ou mais receptores nucleares.

A partir daí, vários estudos foram desenvolvidos com o objetivo de desvendar as bases moleculares de ação deste composto e os primeiros trabalhos já confirmaram essa suposição. Em ensaios de transfecção e gene repórter realizados com células de mamíferos, foi identificado que o cloreto de TBT é agonista dos receptores nucleares PPARy e $\operatorname{RXR\alpha }(22,175)$. Além disso, em ensaio de ligação, também foi demonstrado que este organoestânico se liga com alta afinidade ao LBD destes dois receptores nucleares (22).

Considerando-se que o PPARy tem papel fundamental no processo de adipogênese $(73,176)$, também foram investigados os efeitos do TBT sobre a adipogênese. Células 3T3-L1 (pré-adipócitos) foram cultivadas e tratadas com rosiglitazona, troglitazona ou com cloreto de TBT, na presença ou não do coquetel adipogênico composto por insulina, dexametasona e isobutilmetilxantina (IBMX). Os resultados mostraram que este organoestânico induziu a diferenciação deste tipo celular em adipócitos (175), inclusive quando as células não eram estimuladas pelo coquetel adipogênico $(15,22,177)$. Estes achados foram confirmados pela coloração com óleo vermelho O e pela avaliação da expressão gênica da Fabp4, marcador específico de adipócitos $(22,175,177)$.

Este efeito adipogênico do cloreto de TBT também foi observado em linhagens não comprometidas com a diferenciação adipocitária. Em células mesenquimais humanas $(20)$ e de camundongos $(20,178)$, o tratamento com este organoestânico reduziu a expressão do inibidor adipogênico Pref-1 (proteína associada a diferenciação de adipócitos - adipocyte differentiation-associated protein) e aumentou a expressão dos marcadores adipocitários Fabp4 e PPARY (20).

Além disso, Kirchner e colaboradores (20), usando o antagonista de PPARy T0070907 e Li e colaboradores (21), utilizando o antagonista GW9662, também confirmaram que os efeitos adipogênicos do TBT são dependentes do PPARY, tanto em células comprometidas (21) quanto em não-comprometidas com a diferenciação adipocitária (20).

Para complementar esses achados, mais recentemente foram esclarecidas as bases estruturais pelas quais o cloreto de TBT induz a atividade transcricional do 
RXRa e do PPARy. Em 2009, le Maire e colaboradores compararam a estrutura cristalográfica deste organoestânico ligado ao LBD do RXRa com a estrutura desse mesmo receptor ligado ao seu agonista natural, o ácido 9-cis retinóico. Com uma resolução estrutural de $1.9 \AA$ (angstrons) eles demonstraram que o átomo de estanho do cloreto de TBT faz uma ligação covalente com o átomo de enxofre da cisteína 432 (Cys 432), que fica localizada na hélice 11 (H11) deste receptor. Também foi observado que este composto ocupa apenas parcialmente o sítio de ligação do RXRa fazendo contato com a maior parte dos resíduos que o ácido retinóico se liga (179).

Já em 2015, foi revelada a estrutura tridimensional do cloreto de TBT ligado ao LBD do PPARy. Com uma definição de $1.95 \AA$, foi mostrado que o átomo de estanho deste composto estabelece uma ligação iônica não-covalente com o átomo de enxofre da Cys 285 , localizada na $\mathrm{H} 3$ deste receptor. Neste trabalho também foi demonstrado que, em ensaios de transfecção e gene repórter, o cloreto de TBT ativou parcialmente o PPARy e que a mutação da Cys 285 por uma alanina aboliu totalmente a atividade transcricional deste receptor pelo organoestânico em estudo (71).

Em síntese, os resultados dos trabalhos in vitro mostram que os receptores nucleares são alvos moleculares do cloreto de TBT e que este composto age via PPARY e RXRa, promovendo a adipogênese em cultura de células.

Os efeitos desreguladores endócrinos do cloreto de TBT também foram demonstrados in vivo. Em camundongos adultos tratados durante 24 horas com este composto $(0,3 \mathrm{mg} / \mathrm{kg}$, administrado via intraperitoneal), houve aumento na expressão de genes adipogênicos no tecido adiposo epididimal e no fígado (22). Em outro estudo, a exposição crônica (por 45 dias, desde a puberdade) e repetida (tratamento a cada 3 dias, $5 \mu \mathrm{gg} / \mathrm{kg}$, administrado por gavagem) a este organoestânico provocou em camundongos, além do ganho de peso, esteatose hepática, elevação dos níveis plasmáticos de insulina e leptina e redução dos níveis de adiponectina (23). Adicionalmente, Penza e colaboradores também relataram que camundongos com 9 semanas de idade expostos ao cloreto de TBT por 30 dias ( 0,5 $\mu \mathrm{g} / \mathrm{kg}$, administrado por gavagem) tiveram aumento da massa do tecido adiposo, porém sem mudanças no peso corporal total, na sensibilidade à insulina e na tolerância à glicose (180).

Outro aspecto que tem chamado bastante atenção são os efeitos 
transgeracionais causados pelo cloreto de TBT. Camundongos neonatos expostos a este composto durante o período pré-natal (do $12^{\circ}$ ao $18^{\circ}$ dia de gestação, 0,5 $\mathrm{mg} / \mathrm{kg}$, administrado via intraperitoneal) apresentaram, imediatamente após o nascimento, aumento da adiposidade nos testículos, no fígado e no tecido adiposo inguinal. Além disso, quando esses animais, que tiveram contato com o cloreto de TBT durante o período intra-uterino, eram acompanhados até a vida adulta (10 semanas de idade), foi verificado aumento da massa do tecido adiposo epididimal, apesar de não terem sido observadas diferenças no peso corporal total em relação ao grupo controle (22). Ademais, já foi observado que a exposição pré-natal ao cloreto de TBT produz efeitos até, pelo menos, a geração F3 (considerando como F0 as fêmeas grávidas que tiveram contato com o TBT via água de beber durante toda a gestação, nas concentrações de 5,42, 54,2 ou 542 nM, F1 os animais expostos in utero, F2 aqueles potencialmente expostos como células germinativas e F3 a geração que não teve contato com o composto). Neste estudo, os animais das gerações F1, F2 e F3 foram eutanasiados com 8 semanas de idade. Os resultados mostraram que a geração F3 apresentou aumento significativo no peso de todos os depósitos de gordura do tecido adiposo branco (epididimal, perineal e interescapular), bem como no tamanho e no número dos adipócitos. Além disso, na geração F1, foi observado aumento acentuado no acúmulo de lipídeos no fígado e também na expressão de marcadores de adipogênese neste tecido, induzindo um fenótipo semelhante à doença hepática gordurosa não alcoólica. Embora menos pronunciados, estes efeitos do TBT no fígado também foram verificados nas gerações F2 e F3 (181).

Em resumo, os resultados destes estudos mostram que o cloreto de TBT é um desregulador endócrino que induz a adipogênese agindo via PPARY e RXRa e que, in vivo, dentre outros efeitos, provoca ganho de peso, hiperinsulinemia e acúmulo de gordura no fígado. Entretanto, ainda há várias questões que precisam ser elucidadas, como, por exemplo, investigar o mecanismo pelo qual um agonista de PPARy poderia levar a uma piora da sensibilidade à insulina. Além disso, ainda não se sabe se a exposição ao TBT, ainda durante o desenvolvimento, pode provocar alterações metabólicas a nível populacional em um período de tempo relativamente curto. Esses são apenas alguns questionamentos que mostram serem necessários mais estudos para a melhor compreensão deste complexo mecanismo de ação do cloreto de TBT. 


\subsubsection{Dibutilestanho}

Outro poluente ambiental do grupo dos organoestânicos é o dibutilestanho (DBT), que é constituído por um átomo de $\mathrm{Sn}$ ligado covalentemente a dois grupamentos butil. Várias espécies aniônicas podem ser encontradas associadas a este composto, como por exemplo o diacetato, o dicloreto e o óxido (27). Atualmente, há 18 tipos de DBTs registados na Agência Européia de Produtos Químicos (European Chemicals Agency - ECHA) (182). Além de serem produzidos diretamente como dibutilestanho, os DBTs também são os principais metabólitos do cloreto de TBT, sendo formados no fígado durante um processo que envolve uma progressiva hidroxialquilação dependente de enzimas do citocromo P450 (183). A seguir, são apresentados a estrutura química, o peso molecular e a fórmula linear de cinco destes compostos, o diacetato, o dicloreto, o dilaurato, o maleato e o óxido de dibutilestanho (184-188). 
A

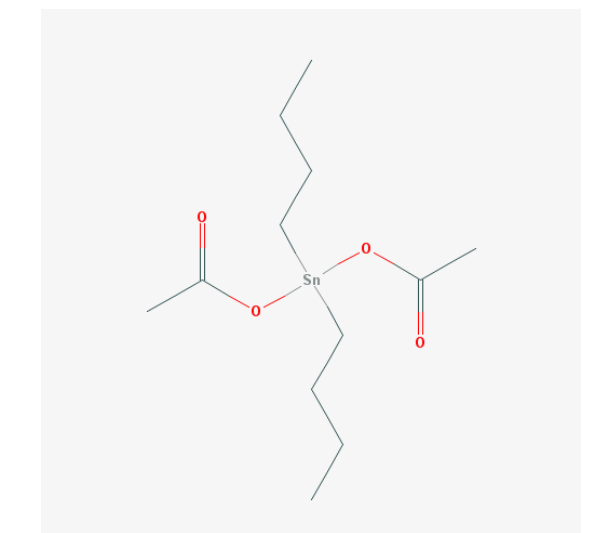

Peso molecular: $351,03 \mathrm{~g} / \mathrm{mol}$ Fórmula linear: $\mathrm{C}_{12} \mathrm{H}_{24} \mathrm{O}_{4} \mathrm{Sn}$

C

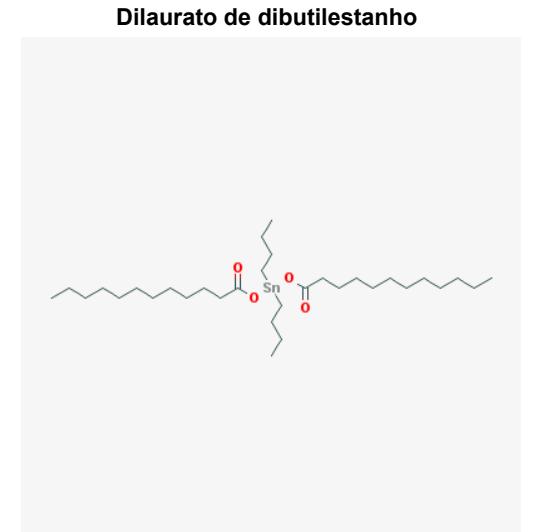

Peso molecular: $631,57 \mathrm{~g} / \mathrm{mol}$ Fórmula linear: $\mathrm{C}_{32} \mathrm{H}_{64} \mathrm{O}_{4} \mathrm{Sn}$

$\mathbf{E}$

Óxido de dibutilestanho

Peso molecular: $248,941 \mathrm{~g} / \mathrm{mol}$ Fórmula linear: $\mathrm{C}_{8} \mathrm{H}_{18} \mathrm{OSn}$

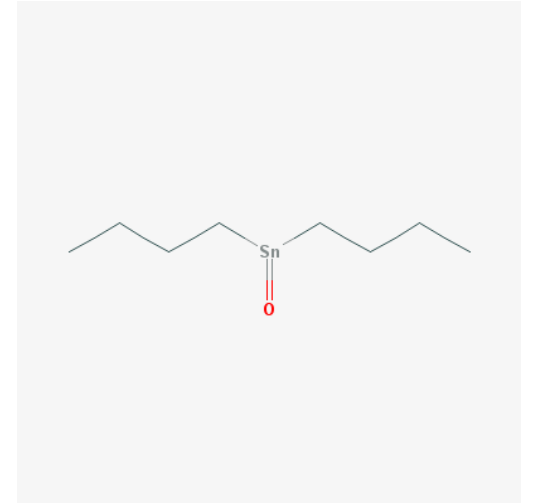

B

Dicloreto de dibutilestanho

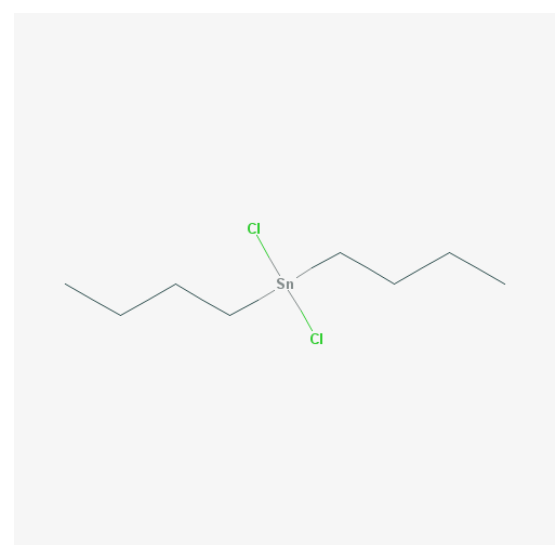

Peso molecular: $303,842 \mathrm{~g} / \mathrm{mol}$ Fórmula linear: $\mathrm{C}_{8} \mathrm{H}_{18} \mathrm{Cl}_{2} \mathrm{Sn}$

D

Maleato de dibutilestanho

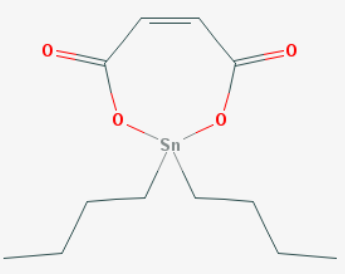

Peso molecular: $346,998 \mathrm{~g} / \mathrm{mol}$ Fórmula linear: $\mathrm{C}_{12} \mathrm{H}_{20} \mathrm{O}_{4} \mathrm{Sn}$

Figura 5. Estrutura química, peso molecular e fórmula linear dos compostos de dibutilestanho. (A) Diacetato de dibutilestanho, (B) Dicloreto de dibutilestanho, (C) Dilaurato de dibutilestanho, (D) Maleato de dibutilestanho e (E) Óxido de dibutilestanho. Fonte: PubChem Compound Database (184188). 
Os DBTs são utilizados, principalmente, como estabilizadores e catalisadores na fabricação de materiais plásticos e de borracha, como os derivados do PVC, os poliuretanos, o silicone e os poliolefínicos (um exemplo deste último são os popularmente denominados de papel filme ou filme de PVC). Também são usados no revestimento de vidros e como biocidas (repelente de roedores, moluscocidas, fungicidas e inseticidas). Desta forma, estes compostos encontram-se presentes em diversos produtos, tais como, canos de água, pneus, roupas, pisos, luvas, embalagens alimentares dentre outros (25-27).

Todas essas aplicações fazem com que o ser humano esteja constantemente em contato com estes organoestânicos (26). Já se sabe, por exemplo, que o consumo de água distribuída por canos de PVC (189) e a ingestão de alimentos, como, por exemplo, bebidas alcóolicas fabricadas e armazenadas em recipientes plásticos ou de vidro produzidos com o dicloreto de DBT $(190,191)$, são importantes fontes de exposição humana à este composto. Porém, apesar destas informações, pouco se sabe sobre as consequências que este contato pode trazer para a saúde humana (26).

Os estudos in vitro e in vivo vêm contribuindo para melhor compreensão de alguns desses efeitos. Assim como o cloreto de TBT, o dicloreto de DBT é considerado hepatotóxico (28), neurotóxico (30) e imunotóxico $(29,192)$. Em camundongos, a hepatotoxicidade induzida por ambos, esteve associada com a depressão da respiração mitocondrial, porém o dicloreto de DBT pareceu apresentar maior afinidade pelas mitocôndrias hepáticas que o cloreto de TBT, estando presente em maior quantidade na fração mitocondrial (28). Em culturas de células derivadas do sistema nervoso central, o dicloreto de DBT também mostrou-se mais tóxico que o cloreto de TBT, impedindo o crescimento e induzindo a morte celular (30). Já em um estudo comparativo, o dicloreto de DBT reduziu cerca de $40 \%$ mais o peso relativo do timo de ratos, quando comparado com o cloreto de TBT (193). A exposição ao DBT também diminuiu os níveis de ATP e a função de lise de células tumorais de linfócitos humanos (natural killer cells) (192).

Baseado em dados de pesquisas experimentais com animais, este composto também é considerado tóxico para reprodução. No estudo realizado por Ema e colaboradores, após o acasalamento bem sucedido, ratos fêmeas Wistar receberam dicloreto de DBT (por gavagem, nas concentrações de 3,8, 7,6 ou 15,2 mg/kg) entre os dias 4 e 7 de gestação. A exposição a este organoestânico, nas duas maiores 
concentrações, afetou negativamente a manutenção da gestação, o que foi demonstrado pela maior incidência de perda embrionária pós-implantação quando comparado com o grupo controle (194). Já em um outro trabalho, ratos fêmeas Wistar grávidas foram expostas ao dicloreto de DBT (administrado por gavagem, nas doses de 20 ou $40 \mathrm{mg} / \mathrm{kg}$ ) entre $\circ 6^{\circ}$ e $\circ 9^{\circ}$ dia de gestação. Os resultados mostraram que o tratamento nos $7^{\circ}$ e $8^{\circ}$ dias, com ambas as doses de DBT, resultou em um aumento da incidência de descendentes com má formações, que foi diretamente proporcional à dose administrada (195). Além disso, também foram comparados os efeitos teratogênicos de cinco diferentes compostos de DBT. Após a administração do diacetato, do dicloreto, do dilaurato, do maleato ou do óxido de DBT (80 $\mu \mathrm{mol} / \mathrm{kg}$, por gavagem, no $8^{\circ}$ dia de gestação de ratos fêmeas), não foram observadas diferenças nos tipos de má formações, sugerindo a importância dos dois grupamentos butil em vez do grupo aniônico para o potencial teratogênico destes compostos (196).

Em relação às bases moleculares de ação dos DBTs, ainda há poucos estudos realizados. Em ensaios de transfecção e gene repórter, foi observado que o dicloreto de DBT não alterou a atividade transcricional do PPARY, sendo considerado um não agonista desta isoforma de $\operatorname{PPAR}(22,197)$. No entanto, se comportou como um agonista parcial do RXRa, quando comparado com o LG100268, agonista sintético específico deste receptor (22). Este composto também inibiu a atividade transcricional do receptor de glicocorticóide (GR), o que o caracteriza como um antagonista de GR (154). Os resultados destes estudos demonstram que, assim como o cloreto de TBT, o dicloreto de DBT também atua como desregulador endócrino agindo via receptores nucleares. Entretanto, além destes trabalhos, não foram encontrados mais dados sobre as ações destes compostos na atividade transcricional de receptores nucleares.

Os efeitos adipogênicos do dicloreto de DBT também já foram demonstrados. Yanik e colaboradores, utilizando células estromais murinas multipotentes (BMS2), mostraram que este composto induziu a diferenciação desta linhagem celular em adipócitos, o que foi evidenciado pela coloração com óleo vermelho $\mathrm{O}$ e pela quantificação do acúmulo de lipídeos intracelular. Quando comparado ao cloreto de TBT, o dicloreto de DBT mostrou um menor efeito adipogênico. Entretanto, neste trabalho não foi comprovado que estes efeitos do DBT ocorriam via PPARy e/ou RXRa (198). 
Ao contrário do cloreto de TBT e também conforme pode ser observado por esta revisão bibliográfica, há poucos trabalhos que investigaram os efeitos biológicos decorrentes da exposição aos compostos de DBT. Além disso, quando realizados, esses são focados principalmente no dicloreto de DBT. No entanto, dados da Associação Européia de Catalisadores de Estanho (European Tin Catalysts Association, ETICA), de 2007, revelaram que cerca de $90 \%$ dos organoestânicos produzidos até aquela data encontravam-se na forma de mono ou dibutilestanho (27).

Ademais, esta carência de estudos com os DBTs levou a Agência Européia de Produtos Químicos (European Chemicals Agency - ECHA) a classificar diferentes tipos de DBTs como tóxicos para a reprodução, porém com base em estudos realizados quase que exclusivamente com o dicloreto de DBT (19). Entretanto, em 2014, essa agência recebeu da empresa TIB Chemicals (uma empresa fornecedora de produtos químicos, incluindo diversos organoestânicos) uma proposta de revisão dessa classificação para o dilaurato de DBT, justificando que os estudos nas quais ela se baseou são antigos e que, provavelmente, havia contaminação deste composto pelo cloreto de TBT (199).

Ainda não existe uma regulamentação específica relacionada ao uso de compostos de dibutilestanho. Porém, considerando os resultados dos estudos já realizados e também a exposição frequente dos seres humanos a estes organoestânicos, a Direção Geral da Comissão Européia das Empresas e da Indústria (European Commission Directorate - General Enterprise and Industry) propôs a substituição dos DBTs como estabilizadores no processo de fabricação de diversos produtos de consumo que utilizam o PVC, tais como camisetas, luvas, sapatos, produtos de higiene feminina, guardanapos e moldes dentários. Contudo, em seu próprio relatório, eles reconhecem as dificuldades dessa substituição, como, por exemplo, os custos que seriam gerados, além da necessidade de desenvolvimento de substitutos que apresentem alto desempenho e, principalmente, que sejam seguros para o meio ambiente e para os seres humanos (27).

Diante deste cenário que envolve exposição frequente dos seres humanos aos DBTs, poucos estudos realizados e focados, principalmente, no dicloreto de DBT, este trabalho se propõe a investigar alguns dos mecanismos celulares e moleculares envolvidos na ação de vários tipos deste organoestânico. 
Esta proposta de pesquisa torna-se extremamente relevante, uma vez que juntamente com outros estudos, poderá contribuir: (i) para uma melhor compreensão dos efeitos destes compostos sobre a saúde humana, (ii) para a regulamentação dos níveis de exposição humana a estes compostos químicos, incluindo a sua síntese e uso, até sua destinação em diferentes contextos, e (iii) para a tomada de decisões visando a reversão de possíveis danos causados à saúde humana e ao meio ambiente em decorrência do uso dos DBTs. 


\section{OBJETIVOS}

\subsection{OBJETIVO GERAL}

Investigar o efeito de quatro compostos de dibutilestanho, o diacetato, o dicloreto, o dilaurato e o maleato de DBT sobre a atividade transcricional dos receptores nucleares PPARy e RXRa e sobre a adipogênese e a inflamação em cultura de células de mamíferos.

\subsection{OBJETIVOS ESPECÍFICOS}

- Verificar os efeitos dos diacetato, dicloreto, dilaurato e maleato de DBT sobre a atividade transcricional dos receptores nucleares PPARy e RXRa em cultura de células HeLa.

- Investigar se a cisteína 285, localizada no LBD do PPARy, é importante para a ativação deste receptor pelos compostos de DBT em estudo.

- Investigar os efeitos dos diacetato, dicloreto, dilaurato e maleato de DBT sobre a adipogênese em cultura de células 3T3-L1.

- Verificar se os efeitos dos diacetato, dicloreto, dilaurato e maleato de DBT na adipogênese são mediados pelo PPARY.

- Investigar os efeitos dos diacetato, dicloreto, dilaurato e maleato de DBT sobre a expressão de genes associados à resposta inflamatória em cultura de células de mamíferos. 


\section{MÉTODOS}

\subsection{MATERIAIS E REAGENTES}

O dimetilsulfóxido (DMSO), o ácido 9-cis retinóico, o cloreto de TBT, o diacetato, o dicloreto, o dilaurato e o maleato de DBT foram obtidos da SigmaAldrich $^{\circledR}$.

A rosiglitazona foi adquirida da Cayman Chemical.

O meio de cultura de células DMEM (Dulbecco's Modified Eagle Medium) e o soro fetal bovino foram obtidos junto à empresa Gibco ${ }^{\circledR}$.

O soro neonatal bovino foi obtido da Sigma-Aldrich ${ }^{\circledR}$.

Os experimentos foram realizados no Laboratório de Farmacologia Molecular da Universidade de Brasília entre os anos de 2014 e 2016.

\subsection{ENSAIO DE CITOTOXICIDADE}

Inicialmente, foi feito um levantamento sobre os compostos de DBT disponíveis para uso em pesquisas científicas. A partir daí, considerando-se a disponibilidade do produto no Brasil e também o seu custo, foram adquiridos cinco derivados de DBT, sendo o diacetato, o dicloreto, o dilaurato, o maleato e o óxido de DBT. Em seguida, foi realizado o ensaio de citotoxicidade, com o objetivo de determinar as máximas concentrações não tóxicas destes compostos para serem utilizadas nos ensaios de transfecção e gene repórter. Apenas o óxido de DBT não pode ser usado, pois não foi possível solubilizá-lo. Os seguintes solventes foram utilizados na tentativa de dissolver este composto: (i) DMSO 100\%, (ii) solução contendo $50 \%$ de DMSO e $50 \%$ de etanol, (iii) etanol 100\% e (iv) metanol 100\%.

A citotoxicidade dos organoestânicos foi determinada por meio da avaliação da atividade mitocondrial das células HeLa e, para isso, foi utilizado um método colorimétrico que usa o reagente MTT (brometo tiazolil azul de tetrazólio 3-(4,5dimetiltiazol-2-il)-2,5-difenil-tetrazólio - adquirido da Sigma-Aldrich ${ }^{\circledR}$ ). O anel de 
tetrazólio do sal de MTT, de cor amarela, é clivado por desidrogenases mitocondriais de células viáveis, formando cristais de formazan, de cor azul. Esta reação ocorre somente em células vivas e, desta forma, considera-se que quanto maior é a quantidade de cristais formados, maior é a quantidade de células viáveis (200).

Este ensaio foi realizado com células HeLa, mesmo tipo celular nos quais foram efetuados os ensaios de transfecção e gene repórter. As HeLa são células epiteliais, derivadas de um adenocarcinoma cervical. São um dos tipos celulares mais utilizados em pesquisas de todo o mundo e foram escolhidas por serem de fácil manuseio, resistentes e por sua capacidade de se proliferarem rapidamente (201).

As células foram semeadas em placas de 96 poços $\left(20 \times 10^{3}\right.$ células por poço) com meio de cultura DMEM acrescido de 10\% de soro fetal bovino, $100 \mathrm{U} / \mathrm{mL}$ de penicilina e $100 \mu \mathrm{g} / \mathrm{mL}$ de estreptomicina, seguida pela incubação das mesmas a $37^{\circ} \mathrm{C}$ com $5 \%$ de $\mathrm{CO}_{2}$.

No dia seguinte ao plaqueamento, as células foram tratadas com veículo (dimetilsulfóxido - DMSO) ou com os organoestânicos em estudo: cloreto de TBT, diacetato, dicloreto, dilaurato ou maleato de DBT. O tratamento foi realizado com concentrações crescentes dos organoestânicos, de $10^{-11} \mathrm{M}$ até as concentrações máximas em que os compostos foram solúveis no veículo (DMSO), que foi de $10^{-4} \mathrm{M}$ para todos os organoestânicos, com exceção do maleato de DBT, cuja concentração máxima foi de $10^{-5} \mathrm{M}$.

Após 24 horas de tratamento, foi adicionado o reagente MTT (10 $\mu \mathrm{L}$ por poço, na concentração de $5 \mathrm{mg} / \mathrm{mL}$ ), seguida pela incubação das células por 4 horas a $37^{\circ} \mathrm{C}$ e $5 \%$ de $\mathrm{CO}_{2}$. Este período foi necessário para a conversão, nas células viáveis, do sal de MTT em cristais de formazan. Em seguida, para a solubilização destes cristais, que são insolúveis em água, foi adicionada aos poços solução de isopropanol ácido (na proporção de $52 \mu \mathrm{L}$ de ácido clorídrico $37 \%$ para cada $12 \mathrm{~mL}$ de isopropanol). As placas foram deixadas sob agitação à temperatura ambiente por 30 minutos e a absorbância foi medida em um espectrofotômetro de placas (DTX 800 Multimode Detector - Beckman Coulter $^{\circledR}$ ) no comprimento de onda de $570 \mathrm{~nm}$.

Os resultados foram interpretados da seguinte forma: (i) os poços nos quais não foram semeadas células e havia somente meio de cultura, foram considerados como "branco", (ii) assumiu-se a viabilidade das células tratadas com veículo como $100 \%$ (controle) e (iii) os poços tratados foram comparados com este controle.

Cada experimento foi realizado em replicatas de seis e repetido duas vezes. 


\subsection{ENSAIO DE TRANSFECÇÃO E GENE REPÓRTER}

O experimento de transfecção e gene repórter permite avaliar a expressão de um determinado gene de interesse, por meio da sua ligação a um gene repórter. Consiste na introdução, ou transfecção, em uma célula eucariota, de vetores contendo as sequências que codificam o gene de interesse e o gene repórter. Como o gene repórter não é normalmente expresso nestas células, a proteína codificada pelo mesmo pode ser facilmente mensurada, servindo como indicador da expressão do gene em estudo.

Este ensaio foi realizado com o intuito de investigar os efeitos dos DBTs sobre a atividade transcricional dos receptores nucleares PPARy e RXRa.

Para isso, os seguintes plasmídeos foram utilizados:

- os que contêm as sequências que codificam os receptores nucleares quiméricos constituídos pelo LBD do PPARY ou do RXRa fusionados ao DBD do fator de transcrição de leveduras GAL4, denominados de LBD-PPARY/DBD-GAL4 e LBD-RXRa/DBD-GAL4, respectivamente;

- e o plasmídeo GAL4-LUC, que possui o elemento responsivo destes receptores (GAL4) fusionado ao gene repórter da luciferase.

Todos estes plasmídeos foram gentilmente cedidos pelo Dr. Paul Webb do Methodist Research Institute (Houston, EUA).

Outro objetivo desse estudo foi verificar se a cisteína 285, localizada no LBD do PPARy, é importante para a ativação deste receptor pelos compostos de DBT em estudo. Este experimento foi realizado baseado em estudos prévios realizados por Harada e colaboradores que mostraram, por meio da estrutura cristalográfica, que o cloreto de TBT realiza uma ligação iônica não covalente com a cisteína 285 e que esta ligação é essencial para a ativação do PPARY por este organoestânico (71). Com o intuito de responder a esta pergunta, foi utilizado um plasmídeo contendo a sequência que codifica o receptor nuclear quimérico constituído pelo LBD do PPARY com a mutação C285S fusionado ao DBD do fator de transcrição de leveduras GAL4, denominado de LBD-PPARYC285S/DBD-GAL4. A mutação sítio dirigida deste PPARY foi realizada pela Dra. Flora Aparecida Milton, conforme descrição prévia e que gentilmente nos cedeu este plasmídeo (202). 
Ao transfectar estes plasmídeos e tratar as células com um agonista de PPARy ou de RXRa, o esperado é que a atividade transcricional destes receptores aumente. E, como o gene repórter da luciferase contém o elemento responsivo destes receptores quiméricos (o GAL4), a luciferase é expressa apenas se os mesmos forem ativados. Desta forma, a expressão da luciferase serve de indicativo da atividade transcricional ou ativação dos receptores nucleares em estudo.

Para a transfecção, células HeLa, as mesmas utilizadas no experimento de citotoxicidade, foram semeadas em placas de 48 poços $\left(40 \times 10^{3}\right.$ células por poço) com meio de cultura DMEM acrescido de $10 \%$ de soro fetal bovino, seguida pela incubação das mesmas a $37^{\circ} \mathrm{C}$ com $5 \%$ de $\mathrm{CO}_{2}$.

No dia seguinte ao plaqueamento, a transfecção foi realizada utilizando o reagente Lipofectamine ${ }^{\circledR} 2000$ Transfection Reagent (Thermo Fisher Scientific) e seguindo as instruções do fabricante. Foram co-transfectados, por poço, $300 \mathrm{ng}$ de DNA plasmidial, na seguinte proporção:

- $60 \mathrm{ng}$ do plasmídeo contendo a sequência que codifica o receptor quimérico LBD-PPARy/DBD-GAL4, LBD-RXRa/DBD-GAL4 ou LBD-PPARYC285S/DBD-GAL 4 e $240 \mathrm{ng}$ do plasmídeo GAL4-LUC, que contém o elemento responsivo destes receptores (GAL4) fusionado ao gene repórter da luciferase.

Seis horas após a transfecção, as células foram tratadas por 24 horas com veículo (DMSO), rosiglitazona $10^{-5} \mathrm{M}$, ácido 9-cis retinóico $10^{-5} \mathrm{M}$, cloreto de TBT, diacetato, dicloreto, dilaurato ou maleato de DBT nas concentrações de $10^{-11} \mathrm{M}$ até a concentração máxima não tóxica observada no ensaio de citotoxicidade. Nas células transfectadas com o PPARy mutante (LBD-PPARyC285S/DBD-GAL4) o tratamento foi feito com a máxima concentração não tóxica de cada um dos compostos organoestânicos. A rosiglitazona (agonista total do PPARY), o ácido 9-cis retinóico (agonista do RXRa) e o cloreto de TBT (agonista dos dois receptores em estudo) foram utilizados como controles positivos.

A atividade da luciferase foi mensurada utilizando o Reporter Luciferase Assay Kit (Promega ${ }^{\circledR}$ ) de acordo com as instruções do fabricante. Nesta etapa, as células foram lisadas e foi adicionado o substrato da luciferase, a luciferina. A luciferase catalisa a oxidação da luciferina em um processo no qual energia química é convertida em luz. Esta luminosidade foi então quantificada em um aparelho luminômetro (GloMax ${ }^{\circledR}$ 20/20 Luminometer - Promega ${ }^{\circledR}$ ) em unidades relativas de luz. $O$ cálculo da atividade transcricional dos receptores, representado pela atividade 
relativa da luciferase, foi feito dividindo-se os valores de unidades relativas de luz das amostras tratadas com os ligantes em estudo pelo valor de unidades relativas de luz das amostras tratadas com veículo.

Os dados foram expressos como média \pm desvio padrão da atividade relativa da luciferase das amostras tratadas com os ligantes comparada ao veículo (DMSO). A análise de variância (ANOVA) seguida pelo post-hoc de Bonferroni foram os testes estatísticos utilizados. O nível de significância adotado foi de $p<0,05$. Todas as análises foram feitas utilizando o programa GraphPad Prism ${ }^{\circledR}$ version 6.0c.

Cada experimento foi realizado em triplicada e repetido no mínimo três vezes.

\subsection{ENSAIO DE DIFERENCIAÇÃO DE ADIPÓCITOS}

A diferenciação de adipócitos in vitro é um ensaio bastante utilizado para a avaliação da adipogênese e que permite explorar os múltiplos mecanismos celulares e moleculares envolvidos neste processo (203).

Neste experimento, com o objetivo de avaliar os efeitos dos DBTs sobre a adipogênese, foi utilizada a linhagem 3T3-L1, células embrionárias de camundongos, já comprometidas com a diferenciação adipocitária e que apresentam morfologia de fibroblastos em cultura. Quando estimuladas a se diferenciarem em adipócitos por um coquetel indutor de diferenciação, composto por insulina, dexametasona e isobutilmetilxantina (IBMX), rapidamente perdem a morfologia fibroblástica, assumindo uma aparência arredondada com gotículas lipídicas podendo ser observadas em seu interior, tornando-se então adipócitos diferenciados. Cada um destes indutores ativa vias sinalizadoras celulares essenciais para a diferenciação das células em adipócitos: a insulina ativa a expressão de genes específicos de adipócitos, a dexametasona ativa o fator de transcrição C/EBP $\beta$ e a IBMX o C/EBPס. O C/EBP $\beta$ e o C/EBPס induzem então a transcrição do C/EBPa e do PPARY (203-205). Esse tipo celular foi escolhido por ser um dos modelos mais bem caracterizados e utilizados para se estudar os eventos moleculares envolvidos na conversão de pré-adipócitos em adipócitos (205-207).

Além disso, como já se sabe que o tecido adiposo secreta uma série de proteínas sinalizadoras que funcionam como mediadores inflamatórios (89), este 
modelo de diferenciação de adipócitos também foi utilizado para estudar os efeitos dos DBTs sobre a expressão de genes inflamatórios neste tipo celular.

O experimento de adipogênese está representado na Figura 6 e foi realizado baseado no protocolo de Kanayama e colaboradores, 2005 (175) que se encontra descrito a seguir.

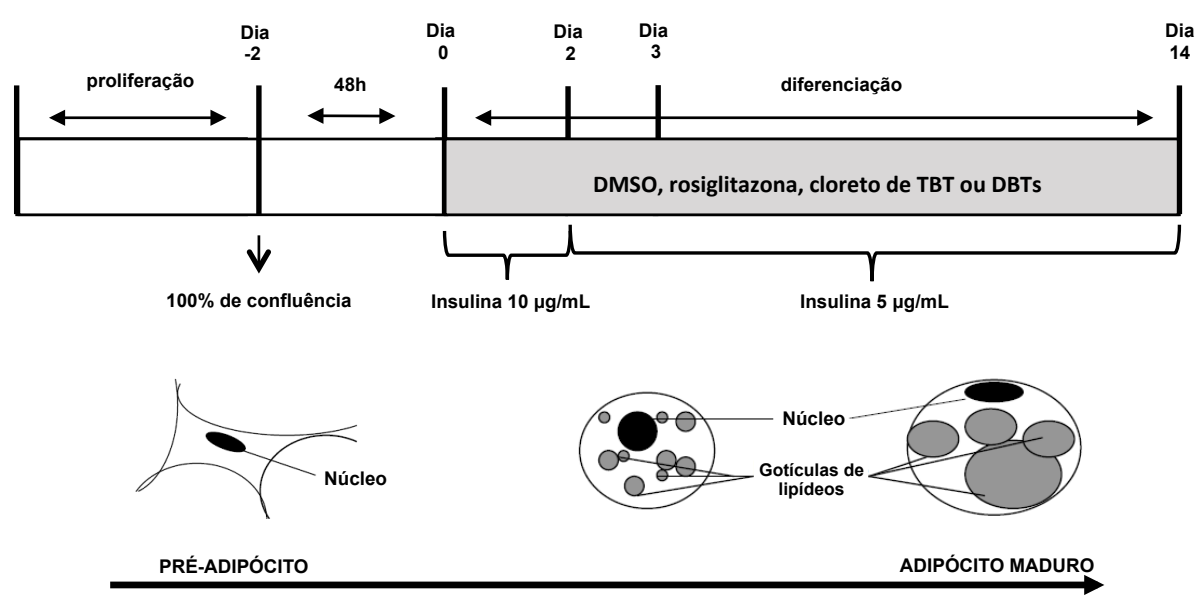

Figura 6. Ensaio de diferenciação de células 3T3-L1.

Células 3T3-L1 foram mantidas em meio de cultura sem indutores de diferenciação até o dia 0. Após esse período, o meio de cultura foi substituído por meio indutor de diferenciação contendo $10 \mu \mathrm{g} / \mathrm{mL}$ de insulina humana (dia 0 ao dia 2). Do dia 2 ao dia 3 ou 14, as células permaneceram em meio de cultura para manutenção de adipócitos contendo $5 \mu \mathrm{g} / \mathrm{mL}$ de insulina humana. Durante todo o período de diferenciação, as células foram tratadas com veículo (DMSO), rosiglitazona, cloreto de TBT ou com os DBTs. (Figura adaptada de Cell Care Manual Maintenance and Differentiation of 3T3L1 Preadipocytes to Adipocytes da ZenBio, 2015 (208)).

Células 3T3-L1 foram semeadas em placas de 6 poços $\left(48 \times 10^{3}\right.$ células por poço) e mantidas em incubadora a $37^{\circ} \mathrm{C}$ e $5 \%$ de $\mathrm{CO}_{2}$ com meio de cultura DMEM acrescido de $10 \%$ de soro neonatal bovino, $100 \mathrm{U} / \mathrm{mL}$ de penicilina e $100 \mu \mathrm{g} / \mathrm{mL}$ de estreptomicina. As células foram mantidas nessas condições até atingirem 100\% de confluência (considerado o dia -2).

Atingida a confluência de $100 \%$, as células permaneceram por mais dois dias, do dia -2 ao dia 0 , sendo cultivadas em iguais condições. Esse período foi necessário para a parada do crescimento, pré-requisito para a diferenciação celular $(203,207)$.

Em seguida, foi realizada a troca do meio de cultura por um meio indutor de diferenciação constituído por DMEM, $10 \%$ de soro fetal bovino, $10 \mu \mathrm{g} / \mathrm{mL}$ de insulina humana, $100 \mathrm{U} / \mathrm{mL}$ de penicilina e $100 \mu \mathrm{g} / \mathrm{mL}$ de estreptomicina, que foi mantido por dois dias (dia 0 ao dia 2). O coquetel indutor de adipogênese composto por insulina, dexametasona e IBMX, constitui um forte estímulo para a diferenciação (205). Por 
isso, com o objetivo de diminuir a ação destes indutores sobre a diferenciação e avaliar o efeito dos organoestânicos sobre esse processo, foi utilizada somente a insulina. Em pré-adipócitos, a insulina não afeta o número de células diferenciadas e sua ação consiste em acelerar o acúmulo de lipídeos intracelulares (203).

No dia 2, o meio de cultura foi novamente substituído por um meio de manutenção de adipócitos constituído por DMEM, $10 \%$ de soro fetal bovino, $5 \mu \mathrm{g} / \mathrm{mL}$ de insulina humana, $100 \mathrm{U} / \mathrm{mL}$ de penicilina e $100 \mu \mathrm{g} / \mathrm{mL}$ de estreptomicina, que foi mantido, com troca de meio a cada 48 horas, até a fixação ou coleta das células.

Durante todo o período de diferenciação, as células foram tratadas com veículo (DMSO), rosiglitazona $10^{-7} \mathrm{M}$ ou com os organoestânicos nas concentrações de $10^{-11} \mathrm{M}$ até a concentração máxima que não induzia a morte neste tipo celular, que foi $10^{-7} \mathrm{M}$ para o cloreto de TBT, o diacetato, o dicloreto e o maleato de DBT e $10^{-5} \mathrm{M}$ para o dilaurato de DBT. O tratamento foi realizado a cada 48 horas, iniciando-se sempre no dia 0.

Nos resultados, são apresentadas as concentrações que provocaram o maior acúmulo lipídico, que coincidiram com as máximas concentrações não tóxicas para este tipo celular ( $10^{-7} \mathrm{M}$ para todos os organoestânicos). A única exceção foi o dilaurato de DBT, cujo maior acúmulo lipídico foi observado na concentração de $10^{-6}$ $\mathrm{M}$, sendo a máxima não tóxica de $10^{-5} \mathrm{M}$.

Também foi avaliado se o potencial adipogênico dos DBTs era mediado pelo PPARY. Para isso, células 3T3-L1 foram diferenciadas e tratadas, seguindo o mesmo protocolo descrito acima, na presença ou na ausência do antagonista de PPARY T0070907 (Cayman Chemical) na concentração de $1 \mu \mathrm{M}$, que foi adicionado ao meio de cultura a cada 12 horas.

O T0070907 é um antagonista específico e que apresenta alta afinidade com o PPARy. Liga-se covalentemente à cisteína 313, localizada na hélice 3 do LBD do PPARY, o que induz uma mudança conformacional que impede a ligação de proteínas coativadoras e favorece o recrutamento de proteínas correpressoras pelo heterodímero PPARy/RXRa. Devido a isso, o T0070907, mesmo na presença de um potente agonista de PPARy, como a rosiglitazona, é capaz de inibir completamente a atividade transcricional deste receptor e também a diferenciação de células 3T3-L1 em adipócitos (209). 
Baseado nessas informações, espera-se que a presença de um antagonista tão potente impeça a ação de agonistas sobre o PPARy e permita avaliar se os efeitos adipogênicos dos DBTs ocorrem via PPARY.

$O$ efeito adipogênico dos DBTs foi avaliado por meio de três métodos: (i) coloração das células com o reagente óleo vermelho O, (ii) Western Blotting e (iii) RT-qPCR (Transcrição reversa seguida por reação em cadeia da polimerase em tempo real/quantitativa).

Já o efeito dos DBTs sobre a expressão de genes inflamatórios foi avaliado por RT-qPCR.

\subsubsection{Coloração com Óleo Vermelho 0}

A coloração das células com óleo vermelho $O$ foi feita no $14^{\circ}$ dia de diferenciação. No protocolo adotado, esse foi o tempo necessário para que pudessem ser observadas células com fenótipo de adipócitos diferenciados, sendo então possível avaliar os efeitos dos tratamentos sobre a adipogênese.

Para a coloração, o meio de cultura foi descartado e as células lavadas duas vezes com solução salina de fosfato para a fixação das mesmas, por 40 minutos, com formaldeído $4 \%$ (Sigma-Aldrich $^{\circledR}$ ). Em seguida, as células foram incubadas durante 1 hora com óleo vermelho $\mathrm{O}$ (Sigma-Aldrich ${ }^{\circledR}$ ), na concentração de 0,5\% dissolvido em isopropanol. Esse reagente pigmenta as gotículas de lipídeos e permite avaliar o acúmulo lipídico pela coloração. Para a fotodocumentação, foi feito o registro de uma área de $9,5 \mathrm{~cm}^{2}$, que corresponde a superfície total de uma cavidade de uma placa de 6 poços.

Este experimento foi repetido, pelo menos, três vezes.

\subsubsection{Western Blotting}

O Western Blotting é uma técnica bastante utilizada em Biologia Molecular que permite detectar proteínas específicas em lisados celulares ou em tecidos. 
Consiste em analisar as amostras por eletroforese em gel de poliacrilamida (que separa as proteínas desnaturadas de acordo com o seu peso molecular), transferir essas proteínas para uma membrana (que contém microporos, nos quais as proteínas se fixam) e adicionar anticorpos específicos para detecção da proteína de interesse. Os detalhes do método encontram-se a seguir.

Decorridos 14 dias de tratamento e diferenciação, tempo necessário para a maturação adipocitária, as 3T3-L1 foram coletadas e lisadas com solução contendo

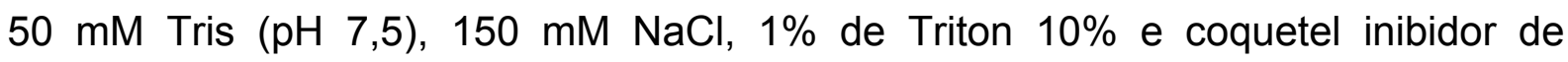
protease (Sigma-Aldrich ${ }^{\circledR}$ ) por 1 hora a $4^{\circ} \mathrm{C}$. A concentração de proteínas totais de cada amostra foi determinada pelo método de Bradford (210), utilizando o reagente Protein Assay Dye Reagent Concentrate (Bio-Rad ${ }^{\circledR}$ ).

Após a quantificação, cada amostra (contendo $12,5 \mu \mathrm{g}$ de proteínas totais) foi fervida em tampão com mercaptoetanol, a $95^{\circ} \mathrm{C}$ por 10 minutos, com o intuito de desnaturar as proteínas. Em seguida, foram aplicadas em gel de poliacrilamida $12,5 \%$ e transferidas para membrana de polivinilideno (PVDF, Millipore ${ }^{\circledR}$ ) utilizando um sistema semi-seco (Semidry Transfer Cell - Bio-Rad ${ }^{\circledR}$ ). O bloqueio da membrana foi feito com solução bloqueadora contendo leite em pó desnatado a $5 \%$ em TBS-T (20 mM de Tris-base, $150 \mathrm{mM}$ de $\mathrm{NaCl}$ e $0,05 \%$ de Tween 20) por 30 minutos em temperatura ambiente.

Para avaliar a expressão da proteína FABP4, marcador específico de adipócitos, a membrana foi incubada com o anticorpo primário anti-FABP4 (produzido em cabra, 195657, abcam ${ }^{\circledR}$ ) em solução bloqueadora a 1\% (fator de diluição de 1:300), por 16 horas, a $4^{\circ} \mathrm{C}$. Após esse período, foi adicionado o anticorpo secundário conjugado à enzima peroxidase (anti-cabra IgG-HRP sc-2354, Santa Cruz Biotechnology ${ }^{\circledR}$ ), também em solução bloqueadora a $1 \%$ (fator de diluição de 1:1000), que permaneceu em contato com a membrana por 45 minutos, à temperatura ambiente. Espera-se que, estando presente a proteína de interesse na amostra, o anticorpo primário se ligue à mesma com consequente ligação do secundário ao primeiro anticorpo.

Em seguida, a proteína FABP4 foi detectada por quimioluminescência com adição à membrana do reagente de detecção Amersham ECL Prime Western Blotting Detection Reagent $\left(\mathrm{GE}^{\circledR}\right)$, que contém o substrato da peroxidase. Nas amostras com expressão de FABP4, a adição deste reagente resultou em emissão de luz (produto da reação da peroxidase com o seu substrato) que foi detectada por 
filme radiográfico $\left(\operatorname{Kodak}^{\circledR}\right)$.

O GAPDH (gliceraldeído-3-fosfato desidrogenase - glyceraldehyde-3phosphate dehydrogenase), utilizado como controle, foi identificado pelo anticorpo primário anti-GAPDH (produzido em cabra, 9483, abcam ${ }^{\circledR}$ ). O objetivo foi comparar qualitativamente a expressão da proteína FABP4 entre as diferentes amostras, considerando como controle a expressão de GAPDH, uma proteína cuja expressão é constitutiva e que não varia com os tratamentos. Para detecção desta proteína controle nas amostras em estudo, foram adotados os mesmos procedimentos descritos acima.

Este experimento foi realizado no mínimo três vezes.

\subsubsection{PCR quantitativa em Tempo Real}

A avaliação dos efeitos dos DBTs sobre a expressão de genes adipogênicos e inflamatórios foi feita através da extração do RNA total seguida pela síntese de DNA complementar (cDNA) por transcrição reversa (RT) e amplificação por reação em cadeia da polimerase em tempo real/quantitativa (RT-qPCR).

Para isso, as células foram tratadas e diferenciadas durante um período de 3 dias, na presença ou ausência do antagonista de PPARY T0070907 (para avaliar a expressão dos genes adipogênicos Adipoq, Fabp4 e Glut4) ou 14 dias (para avaliação da expressão dos genes associados à resposta inflamatória Dcn, Fn1 e Vcam1). O período de diferenciação foi determinado baseado nos resultados de Milton e colaboradores (2015), que mostraram uma maior expressão de genes adipogênicos no princípio da diferenciação (72 horas iniciais) e de genes inflamatórios ao término desse período (em adipócitos maduros) (211).

Optou-se por avaliar a expressão da Adipoq, Fabp4 e Glut4, por serem genes envolvidos no processo de adipogênese, essenciais para que as células adquiram o fenótipo de adipócitos e considerados marcadores específicos deste tipo celular (212). O gene Adipoq codifica a proteína adiponectina, que é secretada por adipócitos e in vivo possui ação sensibilizadora da insulina $(213,214)$. Já o Fabp4 codifica a proteína 4 ligadora de ácidos graxos, que participa dos processos de captação, transporte e metabolismo de ácidos graxos $(212,215)$. Enquanto o Glut4 
codifica a proteína transportadora de glicose tipo 4, um transportador de glicose regulado pela insulina $(212,216)$.

Apesar de não serem genes inflamatórios clássicos, o Dcn, o Fn1 e o Vcam1 foram escolhidos baseado no estudo de Milton e colaboradores (211) que traçaram o perfil de expressão gênica de células 3T3-L1 tratadas com rosiglitazona e GQ-16, um agonista parcial específico de PPARy. Os resultados mostraram que o GQ-16 reprimiu estes genes e, por isso, decidiu-se avaliar os efeitos dos DBTs sobre a expressão dos mesmos. Além disso, também são genes cujas funções estão relacionadas à obesidade e à resistência à insulina.

O gene Dcn (decorin) codifica a decorina, que está envolvida em diversos processos inflamatórios, como no recrutamento de monócitos para o sítio inflamatório (217) e também na inibição da proliferação e apoptose de macrófagos (218). Também está relacionada à inibição da proliferação de pré-adipócitos (219) e atua como um receptor para a resistina em células mesenquimais (220). Já o Fn1 (fibronectin 1) codifica a fibronectina 1, uma glicoproteína que participa de diversos processos inflamatórios (221) e cuja concentração plasmática está correlacionada com a obesidade (222). E o Vcam1 (molécula 1 de adesão celular vascular vascular cell adhesion molecule 1) que codifica uma citocina pró-inflamatória que participa do recrutamento de leucócitos para o sítio inflamatório (223). Sua expressão também está relacionada com o desenvolvimento da arteriosclerose (224, 225).

Os primers utilizados para amplificação destes genes de interesse foram obtidos do NCBI (National Center for Biotechnology Information https://www.ncbi.nlm.nih.gov) e sintetizados pela empresa IDT $^{\circledR}$ (Integrated DNA Technologies). Os critérios para escolha dos primers foram os seguintes: sequência conter entre 20 e 24 nucleotídeos, conteúdo de guanina e citosina (GC) entre 50 e $60 \%$, temperatura de melting de aproximadamente $60^{\circ} \mathrm{C}$, tamanho do produto de amplificação entre 70 e 200 pares de base (bp) e abranger as junções éxon-éxon para evitar a amplificação de DNA genômico. Em seguida, para conferir a especificidade dos primers, foi realizada uma simulação computacional, utilizando o programa In silico PCR (disponível em UCSC Genome Browser Home http://genome.ucsc.edu).

Concluído o período de diferenciação, o RNA total foi extraído das células utilizando-se o reagente TRIzol (Invitrogen ${ }^{\circledR}$ ), conforme instruções do fabricante. Em 
seguida, com o intuito de remover possíveis contaminações por DNA genômico, as amostras foram tratadas com DNase (Amplification Grade DNase I, Sigma-Aldrich ${ }^{\circledR}$ ), também seguindo as recomendações do fabricante. Para quantificação do RNA total e determinação do grau de pureza de cada amostra, foi utilizado o espectrofotômetro NanoDrop 2000 (Thermo Fisher Scientific).

Após a quantificação, utilizando-se o kit Power SYBR ${ }^{\circledR}$ Green RNA-to-CT 1Step (Applied Biosystems), foram efetuadas, em uma única etapa, a transcrição reversa $(\mathrm{RT})$ de 5 ng de RNA total seguida pela amplificação por reação em cadeia da polimerase em tempo real (qPCR).

Todas as reações de RT-qPCR foram realizadas no equipamento StepOnePlus ${ }^{T M}$ Real-Time PCR System (Applied Biosystems) e foram padronizadas da seguinte forma: 30 minutos a $48^{\circ} \mathrm{C}$, para realização da reação de transcrição reversa; 10 minutos a $95^{\circ} \mathrm{C}$, para ativação da enzima DNA polimerase; 40 ciclos de amplificação $\left(95^{\circ} \mathrm{C}\right.$ por 15 segundos para desnaturação e $60^{\circ} \mathrm{C}$ por 1 minuto para anelamento e extensão) e um ciclo de curva de melting (com aumento gradativo da temperatura de $60^{\circ} \mathrm{C}$ para $95^{\circ} \mathrm{C}$ ).

Finalizadas as reações de RT-qPCR, os valores dos Cts obtidos para todos os genes alvos (genes adipogênicos e inflamatórios) foram normalizados em função do controle endógeno (Gapdh): $\Delta \mathrm{Ct}=\mathrm{Ct}$ gene alvo $-\mathrm{Ct}$ Gapdh. Em seguida, a quantificação relativa da expressão dos genes alvos foi feita utilizando-se o método $2^{-\Delta C t}(226)$. Os resultados foram expressos como média \pm desvio padrão da expressão nas amostras tratadas em relação ao veículo (DMSO). A análise estatística foi feita utilizando a análise de variância (ANOVA) seguida pelo post-hoc de Bonferroni. O nível de significância adotado foi de $p<0,05$. Todas as análises foram feitas utilizando o programa GraphPad Prism ${ }^{\circledR}$ version 6.0c.

Cada experimento foi realizado em triplicada e repetido no mínimo duas vezes.

No Apêndice A encontram-se as sequências dos primers assim como todos os dados referentes à validação dos mesmos que incluem: (i) as curvas de melting (mostrando a especificidade dos primers) e (ii) as curvas de eficiência (indicando que a eficiência de amplificação do gene alvo e do gene referência são semelhantes, um pré-requisito para utilização do método $\left.2^{-\Delta C t}\right)(226,227)$. 


\subsection{ENSAIO DE ESTIMULAÇÃO DE MACRÓFAGOS COM LPS}

Além de promover a adipogênese, a ativação do PPARy também está associada a efeitos anti-inflamatórios $(54,228)$. Baseado nestas informações, o objetivo deste ensaio foi explorar melhor a atividade dos DBTs sobre a expressão de genes inflamatórios, porém em um outro tipo celular, em RAW 264.7. Estas células são macrófagos de camundongos derivados de ascites e de tumores induzidos por Vírus da Leucemia Murina de Abelson (229). Foram escolhidas por serem um modelo no qual a resposta inflamatória pode ser facilmente detectada. São células que expressam o PPARy (54) e que quando estimuladas com endotoxinas, como por exemplo lipopolissacarídeo (LPS), secretam uma série de citocinas inflamatórias (TNFa, IL-6, IL1 $\beta)(230,231)$, o que permite avaliar o efeito de ligantes sobre a expressão destes marcadores $(110,111)$.

Com esta finalidade, células RAW 264.7 foram semeadas em placas de 12 poços ( $15 \times 10^{4}$ células por poço) e, 24 horas depois, tratadas com veículo (DMSO), rosiglitazona $10^{-5} \mathrm{M}$, cloreto de TBT $10^{-7} \mathrm{M}$, diacetato $10^{-7} \mathrm{M}$, dicloreto $10^{-7} \mathrm{M}$, dilaurato $10^{-6} \mathrm{M}$ ou maleato $10^{-7} \mathrm{M}$ de DBT. Decorridas 4 horas de tratamento, foi adicionado o LPS $100 \mathrm{ng} / \mathrm{mL}$ (Sigma-Aldrich ${ }^{\circledR}$ ) e 24 horas após, as células foram coletadas para análise da expressão gênica do TNFa.

Optou-se por avaliar a expressão do TNFa por ser um mediador inflamatório clássico e altamente expresso em células RAW 264.7 estimuladas por LPS (230, 231). E também pelo fato de que já se encontra bem relatado na literatura que tanto ligantes naturais como sintéticos de PPARy diminuem a expressão deste marcador $(54,110,111)$.

A expressão do TNFa, feita através da extração do RNA total seguida por RTqPCR, assim como a análise dos dados seguiram o protocolo descrito no item "4.4.3 PCR quantitativa em tempo real".

Este experimento foi realizado em triplicada e repetido três vezes.

No Apêndice A encontram-se as sequências dos primers TNFa e Gapdh (gene de referência) e todos os dados referentes à validação dos mesmos. 


\section{RESULTADOS}

\subsection{AVALIAÇÃO DA CITOTOXICIDADE DOS COMPOSTOS DE DBT}

O experimento de citotoxicidade foi realizado com o intuito de determinar as máximas concentrações não tóxicas dos organoestânicos para serem utilizadas no ensaio de transfecção e gene repórter. Foram consideradas concentrações não tóxicas aquelas que resultaram em uma viabilidade celular igual ou superior a $80 \%$.

Como mostrado na Figura 7 , as concentrações de $10^{-11} \mathrm{M}$ até $10^{-7} \mathrm{M}$ não foram tóxicas para as células tratadas com cloreto de TBT e maleato de DBT. Já para os diacetato e dicloreto de DBT, de $10^{-11} \mathrm{M}$ até $10^{-6} \mathrm{M}$ observou-se uma viabilidade celular média superior a $80 \%$. Dentre os compostos em estudo, o dilaurato de DBT foi o que exibiu menor citotoxicidade, sendo considerada tóxica para as células apenas a concentração de $10^{-4} \mathrm{M}$.

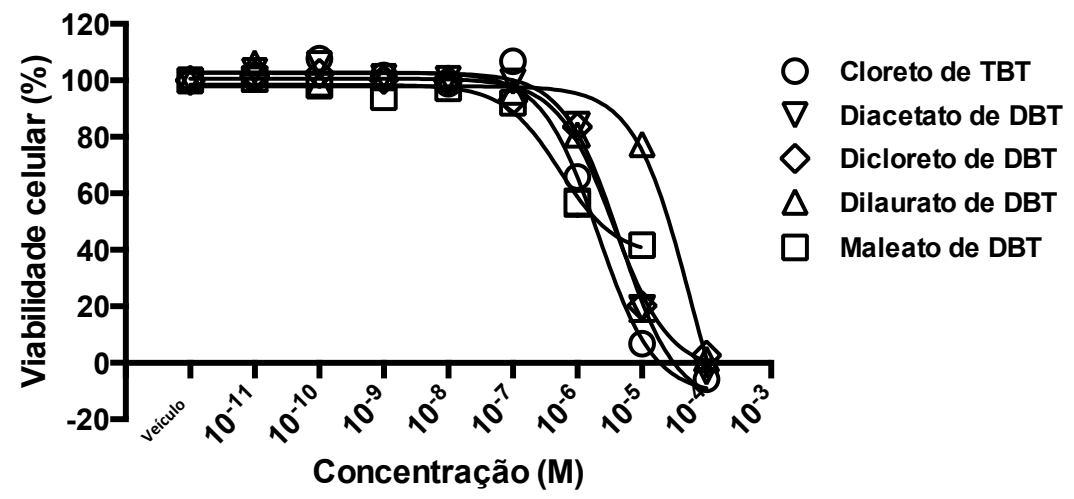

Figura 7. Ensaio de citotoxicidade.

Células HeLa foram tratadas com veículo (DMSO) ou com concentrações crescentes $\left(10^{-11}\right.$ até $10^{-4}$ M) dos organoestânicos em estudo por 24 horas seguida pela incubação com o reagente MTT. Os dados estão apresentados como média \pm desvio padrão do percentual de células viáveis após o tratamento, considerando a viabilidade das células tratadas com veículo como $100 \%$. A figura representa os resultados de dois experimentos independentes realizados em sextuplicata. 


\subsection{OS DBTS SÃO AGONISTAS DE PPARY E RXRa}

Determinadas as máximas concentrações não tóxicas dos organoestânicos que poderiam ser utilizadas no ensaio de transfecção e gene repórter, a próxima etapa foi investigar os efeitos dos compostos de dibutilestanho sobre a atividade transcricional dos receptores nucleares PPARY e RXRa.

Neste ensaio, a rosiglitazona (agonista total do PPARY), o ácido 9-cis retinóico (agonista do RXRa) e o cloreto de TBT (agonista dos dois receptores em estudo) foram utilizados como controles positivos.

Conforme já relatado na literatura, o cloreto de TBT induziu a atividade transcricional do PPARy se comportando como um agonista parcial de PPARy, quando comparado com o agonista total rosiglitazona (Figura 8 A e B).

De forma semelhante ao cloreto TBT, o diacetato, o dicloreto, o dilaurato e o maleato de DBT também ativaram parcialmente o PPARY. O cloreto de TBT, o diacetato, o dilaurato e o maleato de DBT aumentaram a atividade transcricional do PPARY somente nas maiores concentrações utilizadas. Já a ativação promovida pelo dicloreto de DBT foi observada nas duas maiores concentrações (Figura $8 \mathrm{~A}$ e B).

A

\section{Gal4 PPAR $\gamma$}

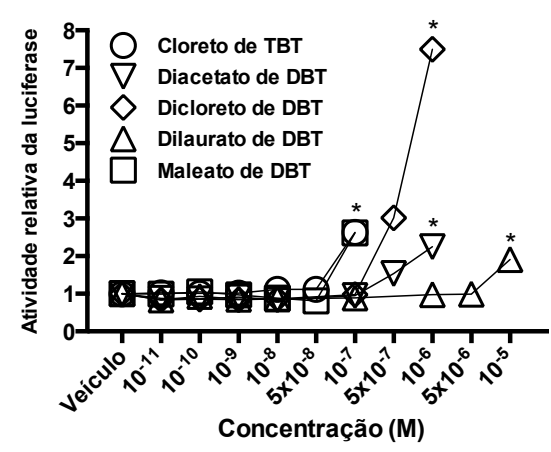

B

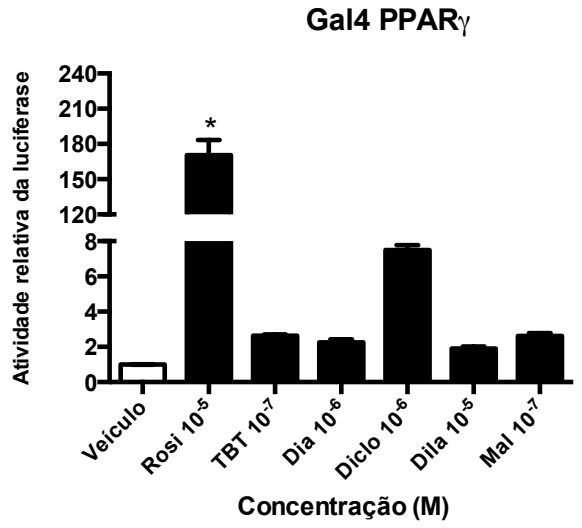

Figura 8. Os DBTs são agonistas de PPARy.

Células HeLa foram co-transfectadas com os plasmídeos contendo os cDNA dos receptores nucleares quiméricos GAL4-PPARy e com o elemento responsivo do GAL4 fusionado ao gene repórter da luciferase. (A) As células foram tratadas com veículo (DMSO), cloreto de TBT (TBT), diacetato (Dia), dicloreto (Diclo), dilaurato (Dila) ou maleato (Mal) de DBT de $10^{-11} \mathrm{M}$ até a máxima concentração não tóxica (B) ou com veículo (DMSO), rosiglitazona (Rosi) $10^{-5} \mathrm{M}$ ou com as máximas concentrações não tóxicas de cada um dos compostos organoestânicos. Os dados estão expressos como média \pm desvio padrão da atividade relativa da luciferase das amostras tratadas com os ligantes em relação às amostras tratadas com veículo (DMSO). A figura representa os resultados de três experimentos independentes realizados em triplicata. * $p \leq 0,01$ (comparado ao veículo). 
Da mesma forma, em concordância com resultados previamente descritos, o cloreto de TBT também induziu a atividade transcricional do RXRa ativando de forma total este receptor, promovendo uma ativação cerca de três vezes maior do que a provocada pelo agonista natural ácido 9-cis retinóico (Figura 9 A e B).

Já entre os compostos de dibutilestanho, somente o dicloreto e o dilaurato de DBT ativaram o RXRa e, diferente do cloreto de TBT, de forma parcial. A ativação do RXRa promovida pelo cloreto de TBT foi observada nas três maiores concentrações utilizadas, enquanto que para os dicloreto e dilaurato de DBT, ocorreu apenas nas maiores concentrações (Figura 9 A e B).

A

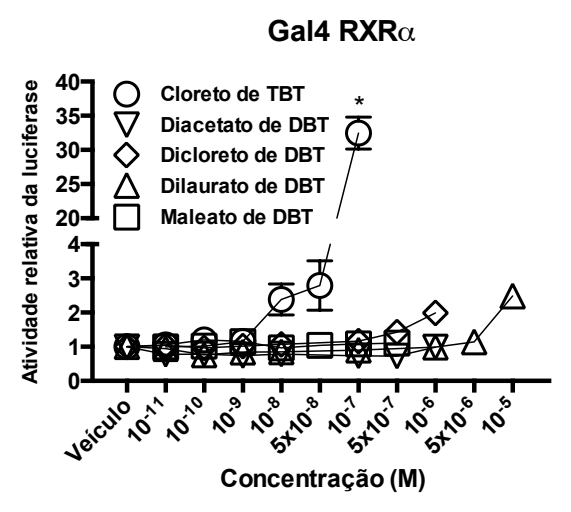

B

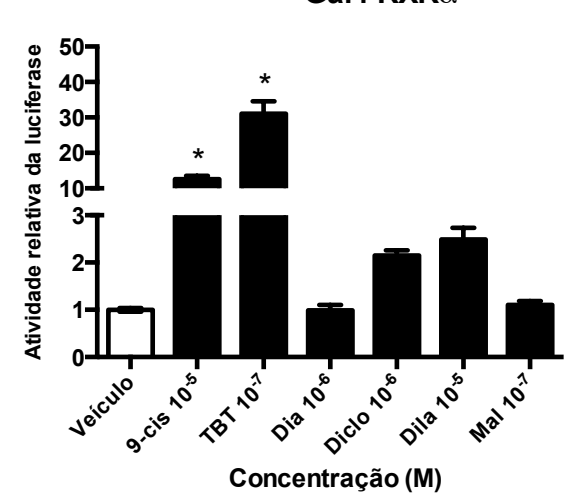

Figura 9. Os DBTs são agonistas de RXRa.

Células HeLa foram co-transfectadas com os plasmídeos contendo os cDNAs dos receptores nucleares quiméricos GAL4-RXRa e com o elemento responsivo do GAL4 fusionado ao gene repórter da luciferase. (A) As células foram tratadas com veículo (DMSO), cloreto de TBT (TBT), diacetato (Dia), dicloreto (Diclo), dilaurato (Dila) ou maleato (Mal) de DBT de $10^{-11} \mathrm{M}$ até a máxima concentração não tóxica (B) ou com veículo (DMSO), ácido 9-cis retinóico (9-cis) $10^{-5} \mathrm{M}$ ou com as máximas concentrações não tóxicas de cada um dos compostos organoestânicos. Os dados estão expressos como média \pm desvio padrão da atividade relativa da luciferase das amostras tratadas com os ligantes em relação às amostras tratadas com veículo (DMSO). A figura representa os resultados de três experimentos independentes realizados em triplicata. * $p \leq 0,0001$ (comparado ao veículo).

\subsection{A CISTEÍNA 285 É IMPORTANTE PARA A ATIVAÇÃO DO PPARY PELOS DBTS}

Após os achados de que os quatro compostos de dibutilestanho em estudo são agonistas do PPARy, decidiu-se investigar se a cisteína 285 é importante para a atividade transcricional deste receptor induzida pelos DBTs. Este experimento foi 
realizado baseado em resultados prévios que mostraram que a ativação do PPARY pelo cloreto de TBT é dependente da cisteína 285 (71).

Os resultados mostraram que a substituição da cisteína pela serina na posição 285 no LDB do PPARy aboliu a atividade transcricional do PPARy induzida por todos os compostos em estudo, mostrando que este resíduo é essencial para a ativação do PPARy por estes organoestânicos (Figura 10).

\section{Gal4 PPAR $\gamma$}

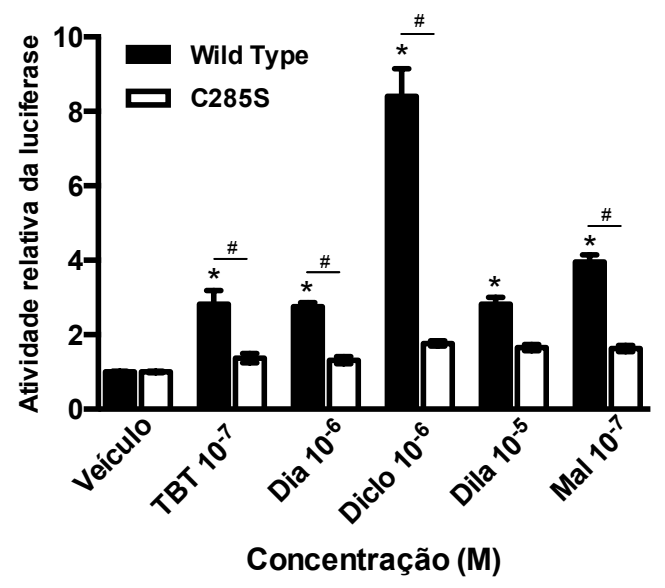

Figura 10. A cisteína 285 é importante para a ativação do PPARY pelos DBTs.

Células HeLa foram co-transfectadas com o plasmídeo wild type (selvagem) contendo o cDNA do receptor nuclear quimérico GAL4-PPARY ou com o mutante GAL4-PPARYC285S e com o elemento responsivo do GAL4 fusionado ao gene repórter da luciferase. As células foram tratadas com veículo (DMSO) ou com as máximas concentrações não tóxicas de cada um dos compostos organoestânicos, cloreto de TBT (TBT), diacetato (Dia), dicloreto (Diclo), dilaurato (Dila) ou maleato (Mal) de DBT. Os dados estão expressos como média \pm desvio padrão da atividade relativa da luciferase das amostras tratadas com os ligantes em relação às amostras tratadas com veículo (DMSO). A figura representa os resultados de três experimentos independentes realizados em triplicata. ${ }^{*} p \leq 0,0001$ (comparado ao veículo) e \# $p \leq 0,01$ wild type versus mutante C285S.

\subsection{OS DBTS INDUZEM A ADIPOGÊNESE EM CULTURA DE CÉLULAS}

Já se sabe que o PPARy é um dos principais reguladores da adipogênese e, baseado nos resultados de que os DBTs são agonistas parciais deste receptor, decidiu-se então por avaliar os efeitos destes compostos sobre a diferenciação de adipócitos em cultura de células.

Por meio da análise da coloração com óleo vermelho $O$, foi possível observar que todos os DBTs promoveram o acúmulo de lipídeos (Figura $11 \mathrm{~A}$ ). 
Foram também avaliadas as expressões gênica e proteica da Fabp4, um marcador específico de adipócitos, e os resultados estão de acordo com os do acúmulo lipídico observado pela pigmentação com o reagente óleo vermelho 0 (Figura $11 \mathrm{~A}$ e B).

De forma semelhante, também houve um aumento significativo na expressão dos genes relacionados à adipogênese, Adipoq e Glut4, nos pré-adipócitos induzidos a se diferenciarem na presença dos compostos organoestânicos avaliados. A única exceção foi o diacetato de DBT, cuja expressão dos marcadores adipogênicos não foi diferente do controle (células tratadas com veículo) (Figura 11 C).

A

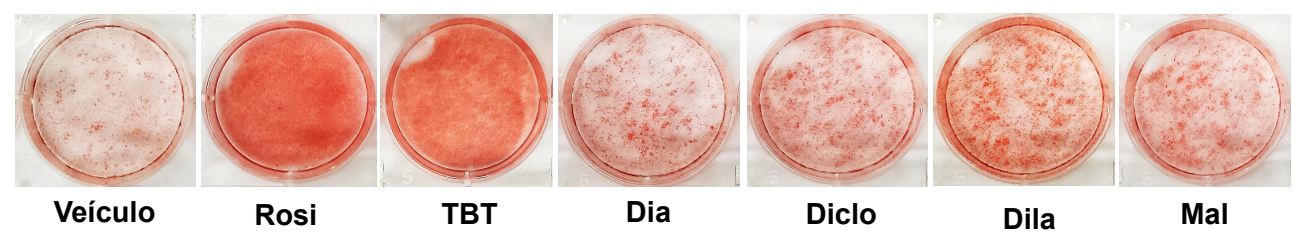

B

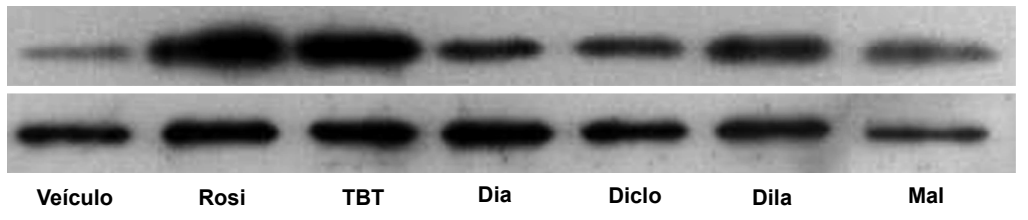
FABP4 (15 kDa) GAPDH (37 kDa)

C
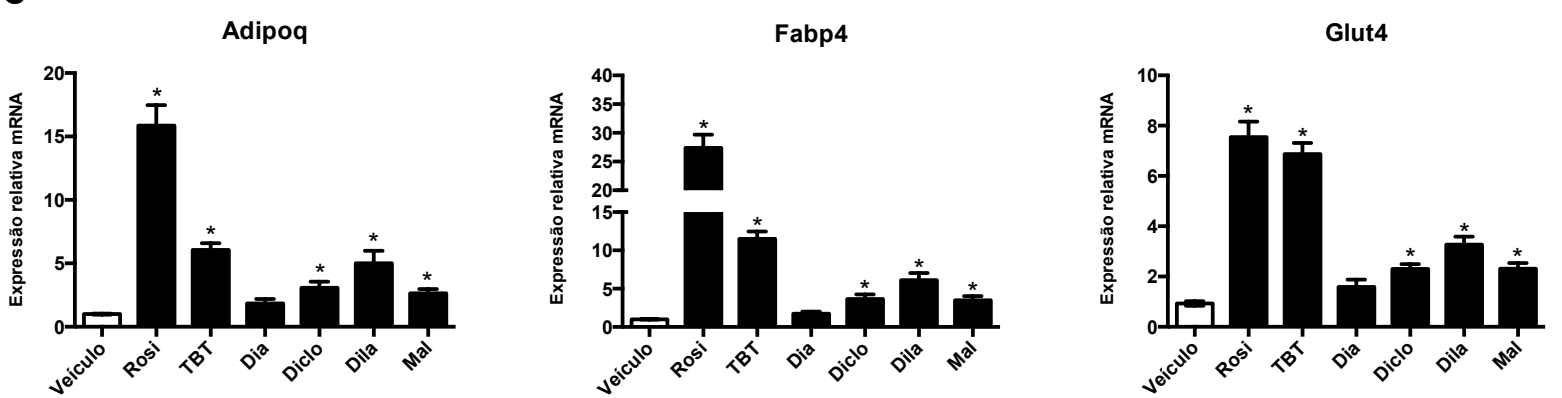

Figura 11. Os DBTs induzem a adipogênese em cultura de células 3T3-L1.

Células 3T3-L1 foram induzidas a se diferenciarem em adipócitos com insulina e tratadas com veículo (DMSO), rosiglitazona (Rosi) $10^{-7} \mathrm{M}$, cloreto de TBT (TBT) $10^{-7} \mathrm{M}$, diacetato (Dia) $10^{-7} \mathrm{M}$, dicloreto (Diclo) $10^{-7} \mathrm{M}$, dilaurato (Dila) $10^{-6} \mathrm{M}$ ou maleato (Mal) $10^{-7} \mathrm{M}$ de DBT durante todo o período de diferenciação. (A) As células foram diferenciadas por 14 dias, fixadas, coradas com óleo vermelho $O$ e fotodocumentadas (registro de uma área de $9,5 \mathrm{~cm}^{2}$ ). (B) As células foram diferenciadas por 14 dias e lisadas para avaliação da expressão da proteína FABP4 por Western Blotting. (C) As células foram diferenciadas por 3 dias e coletadas para avaliação da expressão dos genes Fabp4, Adipoq e Glut4 por PCR quantitativa em tempo real. Os dados estão expressos como média \pm desvio padrão dos níveis de transcritos dos ligantes em relação ao veículo (DMSO). Estes resultados se reproduziram em, pelo menos, três experimentos independentes. ${ }^{*} p \leq 0,05$ (comparado ao veículo). 


\subsection{O EFEITO ADIPOGÊNICO DOS DBTS É DEPENDENTE DO PPARY}

Baseado nos resultados que mostraram que os DBTs promoviam a adipogênese em cultura de células, o próximo passo foi investigar se estes efeitos ocorriam via PPARy. Para isso, foi utilizado um potente antagonista desta isoforma do receptor.

O co-tratamento das células 3T3-L1 com o antagonista específico de PPARy T0070907 reduziu o acúmulo de lipídeos induzido pelos organoestânicos, o que pode ser constatado pela comparação da coloração com o óleo vermelho $\mathrm{O}$ e da expressão gênica da Fabp4 entre as células tratadas e não tratadas com o antagonista (Figura $12 \mathrm{~A}$ e B). Estes resultados sugerem que o efeito adipogênico destes compostos é dependente do PPARy.

A redução da expressão gênica da Fabp4 nas células tratadas com T0070907, em relação às não tratadas, foi menor para o cloreto de TBT do que para os demais compostos avaliados (Figura $12 \mathrm{~B}$ ).

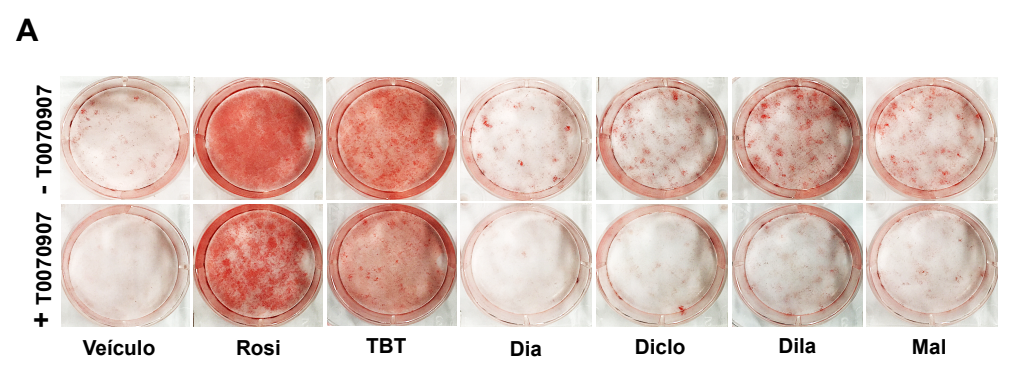

\section{в}

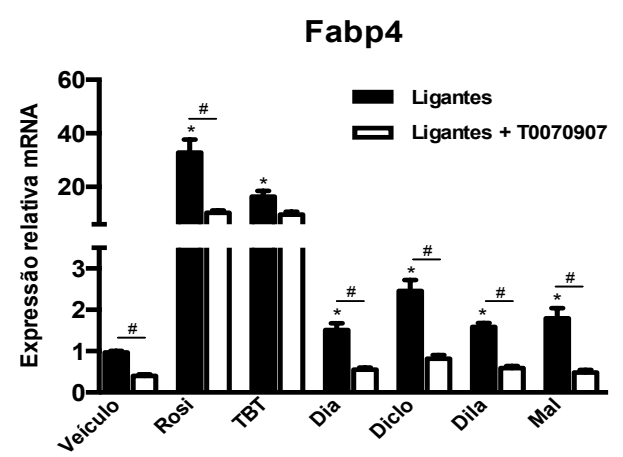

Figura 12. O efeito adipogênico dos DBTs é dependente do PPARy.

Células 3T3-L1 foram induzidas a se diferenciarem em adipócitos com insulina e tratadas com veículo (DMSO), rosiglitazona (Rosi) $10^{-7} \mathrm{M}$, cloreto de TBT (TBT) $10^{-7} \mathrm{M}$, diacetato (Dia) $10^{-7} \mathrm{M}$, dicloreto (Diclo) $10^{-7} \mathrm{M}$, dilaurato (Dila) $10^{-6} \mathrm{M}$ ou maleato (Mal) $10^{-7} \mathrm{M}$ de DBT na presença ou na ausência de T0070907 $10^{-6} \mathrm{M}$. (A) Células diferenciadas por 14 dias, fixadas, coradas com óleo vermelho $\mathrm{O}$ e fotodocumentadas (registro de uma área de $9,5 \mathrm{~cm}^{2}$ ). (B) Células diferenciadas por 3 dias e coletadas para avaliação da expressão do gene Fabp4 por PCR quantitativa em tempo real. Dados expressos como média \pm desvio padrão dos níveis de transcritos dos ligantes em relação ao veículo (DMSO). Resultados reproduzidos em, pelo menos, três experimentos independentes. * $p$ $\leq 0,01$ (comparado ao veículo na ausência do T0070907) e \# $p \leq 0,001$ (comparando o mesmo ligante na presença e na ausência de T0070907). 


\subsection{OS DBTS REPRIMEM GENES RELACIONADOS À RESPOSTA INFLAMATÓRIA EM CULTURA DE CÉLULAS}

O tecido adiposo secreta uma série de proteínas sinalizadoras que funcionam como mediadores inflamatórios (89). Além disso, já se encontra bem relatado na literatura que a ativação do PPARy diminui a expressão destes genes $(54,228)$. Considerando-se que tanto o cloreto de TBT quanto os DBTs avaliados são agonistas parciais deste receptor, também foram verificados os efeitos desses compostos sobre a expressão de genes associados à resposta inflamatória em células induzidas a se diferenciarem em adipócitos.

$\mathrm{Na}$ linhagem celular 3T3-L1, todos os organoestânicos estudados reprimiram a expressão de genes relacionados à resposta inflamatória aqui avaliados, o Dcn, o Fn1 e o Vcam1. A exceção foi o diacetato de DBT que não suprimiu a expressão do Dcn e Vcam1. O cloreto de TBT apresentou efeito inibitório semelhante ao da rosiglitazona, enquanto os dicloreto, dilaurato e maleato de DBT mostraram efeito moderado sobre os genes avaliados (Figura 13).
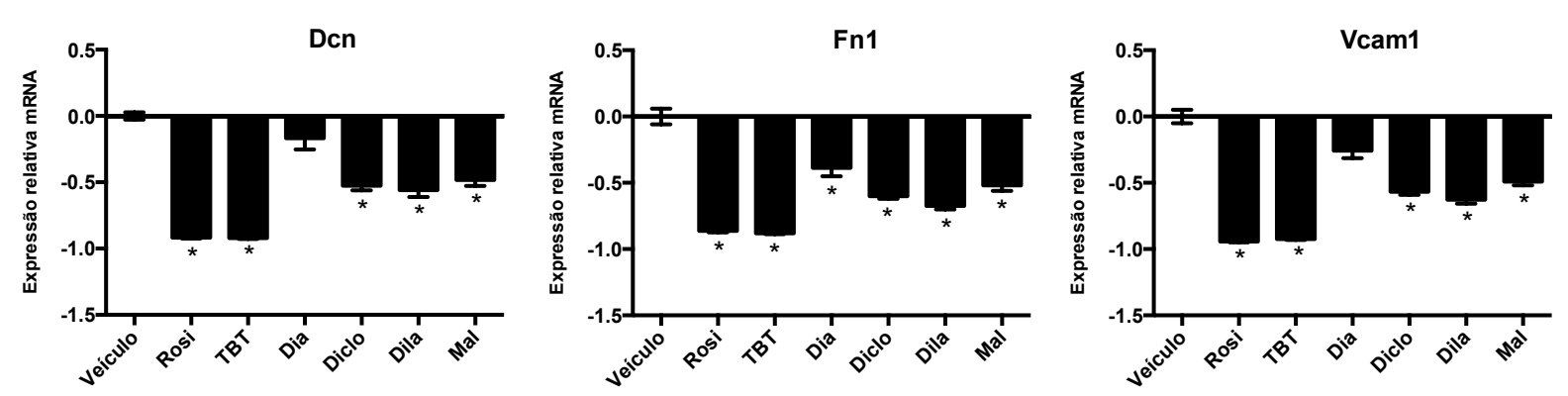

Figura 13. Os DBTs reprimem genes relacionados à resposta inflamatória em células 3T3-L1. Células 3T3-L1 foram induzidas a se diferenciarem em adipócitos com insulina e tratadas com veículo (DMSO), rosiglitazona (Rosi) $10^{-7} \mathrm{M}$, cloreto de TBT (TBT) $10^{-7} \mathrm{M}$, diacetato (Dia) $10^{-7} \mathrm{M}$, dicloreto (Diclo) $10^{-7} \mathrm{M}$, dilaurato (Dila) $10^{-6} \mathrm{M}$ ou maleato (Mal) $10^{-7} \mathrm{M}$ de DBT por 14 dias. Em seguida foram coletadas para avaliação da expressão dos genes Dcn, Fn1 e Vcam1 por PCR quantitativa em tempo real. Dados expressos como média \pm desvio padrão dos níveis de transcritos dos ligantes em relação ao veículo (DMSO). A figura representa os resultados de três experimentos independentes realizados em triplicata. ${ }^{*} p \leq 0,01$ (comparado ao veículo). 
Já em células RAW 264.7, como já era esperado, em todas as amostras, o estímulo com LPS aumentou significativamente a expressão de TNFa. Porém, apenas o cloreto de TBT e o dilaurato de DBT conseguiram reduzir de forma significativa esta expressão, quando comparados às amostras tratadas com veículo e estimuladas com LPS (Figura 14).

TNF $\alpha$

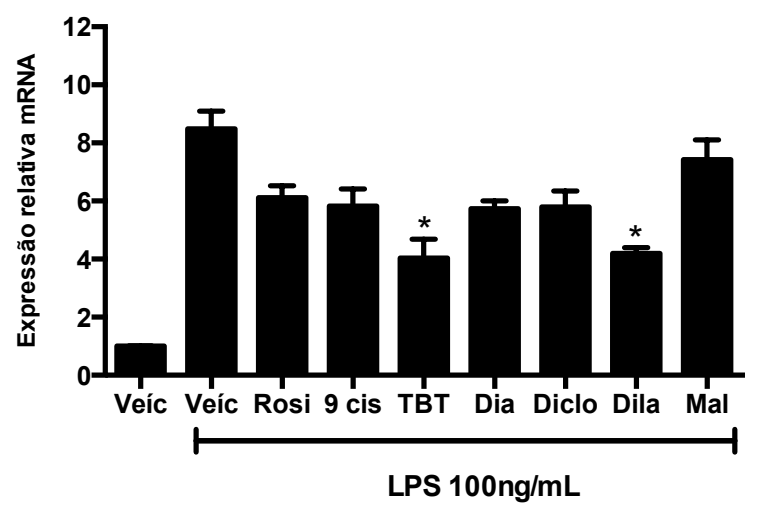

Figura 14. Os DBTs reprimem genes associados à resposta inflamatória em células RAW 264.7. Células RAW 264.7 foram tratadas com veículo (Veíc), rosiglitazona (Rosi) $10^{-5} \mathrm{M}$, ácido 9-cis retinóico (9 cis) $10^{-5} \mathrm{M}$, cloreto de TBT (TBT) $10^{-7} \mathrm{M}$, diacetato (Dia) $10^{-6} \mathrm{M}$, dicloreto (Diclo) $10^{-7} \mathrm{M}$, dilaurato (Dila) $10^{-6} \mathrm{M}$ ou maleato (Mal) $10^{-7} \mathrm{M}$ de DBT. Após 4 horas, foram tratadas com LPS 100 $\mathrm{ng} / \mathrm{mL}$ e, depois de 24 horas, coletadas para análise da expressão gênica do TNFa por PCR quantitativa em tempo real. Dados expressos como média \pm desvio padrão dos níveis de transcritos dos ligantes em relação ao veículo (DMSO). A figura representa os resultados de três experimentos independentes realizados em triplicata. ${ }^{*} p \leq 0,01$ (comparado às amostras veículo + LPS). 


\section{DISCUSSÃO}

Atualmente, há 18 tipos de compostos de DBT registrados na Agência Européia de Produtos Químicos (European Chemicals Agency - ECHA) e, segundo dados do Espaço Econômico Europeu (European Economic Area - EEA), cerca de 10 a 100 toneladas deste organoestânico são fabricados e/ou importados por ano (182).

Devido a isso, há uma crescente preocupação sobre o fato de se saber tão pouco sobre compostos com os quais os seres humanos estão continuamente em contato. Deste modo, buscando contribuir para a geração de mais conhecimentos sobre esse assunto, o objetivo deste estudo foi investigar o efeito de quatro destes compostos, o diacetato, o dicloreto, o dilaurato e o maleato de DBT sobre a atividade transcricional dos receptores nucleares PPARy e RXRa e também sobre a adipogênese e a inflamação em cultura de células de mamíferos.

A atividade agonista do cloreto de TBT sobre o PPARY $(22,175)$, bem como os seus efeitos adipogênicos em cultura de células mediados por este receptor (20, 21), já foram relatados na literatura. Porém, até o momento, nenhum outro estudo havia mostrado que os compostos de dibutilestanho são agonistas parciais do PPARy e que também promovem a adipogênese em cultura de células.

No presente estudo, o cloreto de TBT e todos os DBTs avaliados ativaram parcialmente o PPARy. Em ensaios de transfecção e gene repórter, o diacetato, o dilaurato e o maleato de DBT, nas maiores concentrações utilizadas $\left(10^{-6} \mathrm{M}, 10^{-5} \mathrm{M}\right.$ e $10^{-7} \mathrm{M}$, respectivamente), induziram a atividade transcricional do PPARY de maneira bem similar ao cloreto de TBT. Já o dicloreto de DBT (na concentração de $10^{-6} \mathrm{M}$ ) promoveu uma ativação cerca de três vezes maior que a atingida pelo cloreto de TBT (a 10-7 M). Embora este resultado, de que o cloreto de TBT é um agonista parcial de PPARy, já tenha sido descrito anteriormente $(22,175,179)$, a atividade agonista de compostos de DBT neste receptor nuclear ainda não havia sido mostrada, havendo poucos relatos na literatura. Em 2006, Grun e colaboradores descreveram que o dicloreto de DBT não alterou a atividade transcricional do PPARy (22). E, em 2009, Hiromori e colaboradores também investigaram os efeitos deste DBT sobre a atividade transcricional do PPARY e, da mesma forma, não encontraram nenhum efeito significativo (197). Alguns aspectos 
podem ajudar a explicar as diferenças entre os resultados do presente estudo e dos demais, como: (i) o tipo celular utilizado (HeLa no presente trabalho, Cos-7 no estudo de Grun et al. (22) e JEG-3 no estudo de Hiromori et al. (197)) e (ii) a concentração utilizada do dicloreto de DBT, que no presente estudo foi dez vezes maior $\left(10^{-6} \mathrm{M}\right)$ que a usada por Hiromori e colaboradores $\left(10^{-7} \mathrm{M}\right)$. Grun e colaboradores não informaram a concentração empregada do referido organoestânico.

Foi mostrado ainda que o cloreto de TBT ativou o RXRa, comportando-se como um agonista total. Entre os compostos de DBT, apenas o dicloreto e o dilaurato de DBT ativaram este receptor, porém, de forma parcial. O agonismo total observado com o cloreto de TBT no RXRa já havia sido descrito anteriormente (22, $175,179)$, assim como a ativação parcial deste receptor pelo dicloreto de DBT (22). No entanto, este é o primeiro relato de que o dilaurato de DBT ativa o RXRa.

Outro achado relevante deste trabalho foi que a cisteína 285 é importante para a ativação do PPARY pelos DBTs. Em 2015, Harada e colaboradores publicaram a estrutura cristalográfica do cloreto de TBT ligado ao LBD do PPARY e mostraram que o átomo de estanho do cloreto de TBT estabelece uma ligação iônica não-covalente com o átomo de enxofre da Cys 285, localizada na H3 do PPARY (71). No presente estudo, usando um plasmídeo que expressa o LBD do PPARY com a mutação C285S, observou-se que, de maneira bem semelhante ao que foi mostrado anteriormente para cloreto de TBT (71), a atividade transcricional induzida pelos DBTs foi abolida quando a Cys 285 foi substituída por uma serina. Esses resultados sugerem que, assim como o cloreto de TBT, pode haver uma interação entre o resíduo de cisteína do PPARy e o átomo de estanho dos compostos de DBT. Importante ressaltar que este aminoácido também é essencial para a ativação do PPARY por ligantes endógenos, como a prostaglandina $\mathrm{J} 2$ e os ácidos eicosatetraenóicos oxidados (66). Desta forma, os resultados do presente estudo sugerem que os DBTs se ligam ao bolso de ligação do PPARY de modo semelhante ao cloreto de TBT.

A investigação do presente estudo sobre os efeitos dos DBTs em células 3T3L1 mostraram que estes compostos induziram a adipogênese, porém em menor intensidade que o cloreto de TBT. Este efeito adipogênico do cloreto de TBT já foi observado anteriormente em pré-adipócitos 3T3-L1, tanto na presença (175) quanto na ausência do coquetel adipogênico $(15,22,177)$. $E$, similarmente, já foram 
relatados em células mesenquimais humanas (20) e de camundongos $(20,178)$, linhagens não comprometidas com a diferenciação adipocitária.

$O$ efeito adipogênico de todos os compostos testados foram confirmados pela expressão dos genes relacionados à adipogênese Fabp4, Adipoq e Glut4, que foram consistentes com os resultados de acúmulo lipídico evidenciado pela coloração com óleo vermelho $\mathrm{O}$. O cloreto de TBT provocou um grande aumento na expressão destes genes, enquanto que os DBTs causaram uma elevação moderada. Apenas os efeitos do diacetato de DBT sobre a adipogênese não foram significativos.

A expressão da Fabp4 induzida pelo cloreto de TBT em células 3T3-L1 está de acordo com resultados já publicados na literatura $(22,175)$. Os efeitos deste composto na expressão de Fabp4 e de outros genes relacionados à adipogênese, como PPARy e leptina, também já foi demonstrado em células mesenquimais humanas $(20)$ e de camundongos $(20,178)$.

Um aspecto observado no presente estudo foi que as concentrações de TBT e DBTs utilizadas para induzir a diferenciação de células 3T3-L1 em adipócitos não foram as mesmas que provocaram a ativação do PPARY nos ensaios de transfecção e gene repórter. Esta diferença pode estar relacionada ao próprio contexto celular, já que foram utilizadas células de camundongos nos experimentos de adipogênese e células humanas nos ensaios de transativação.

Foram também confirmados que os efeitos adipogênicos dos DBTs ocorrem via PPARy. Kirchner e colaboradores, usando o antagonista de PPARY T0070907 (20) e Li e colaboradores utilizando o GW9662 (21), já haviam comprovado que o cloreto de TBT promove a adipogênese de forma dependente do PPARy. De maneira semelhante, no presente estudo também foi utilizado o T0070907, o que resultou em uma redução considerável no acúmulo de lipídeos induzidos pelos DBTs. Entretanto, também foi observada uma menor capacidade deste antagonista em inibir a adipogênese induzida tanto pela rosiglitazona, como pelo cloreto de TBT. Esta insuficiência do T0070907 de inibir os efeitos adipogênicos da rosiglitazona já foi relatada previamente por Kirchner e colaboradores, que atribuíram à quantidade de rosiglitazona utilizada, que foi dez vezes maior que a quantidade do antagonista T0070907 (20). Porém, no presente estudo, este efeito continuou sendo observado, mesmo usando uma concentração de T0070907 $\left(10^{-6} \mathrm{M}\right)$ dez vezes maior que a de rosiglitazona $\left(10^{-7} \mathrm{M}\right)$.

Este antagonista, que é específico de PPARy, recruta os correpressores 
NCoR e SMRT para o heterodímero PPARy/RXRa, impedindo a transcrição dos genes alvos do PPARy (209). No entanto, mesmo na presença do antagonista, quando há agonistas de RXRa (que é o caso do cloreto de TBT), este recrutamento é inibido. E, pelo fato de se tratar de um heterodímero permissivo, isso acaba ativando o PPARy e induzindo a diferenciação. Desta forma, dependendo da concentração e da disponibilidade, a atividade do T0070907 pode ser influenciada por ligantes de RXRa (209). Além disso, recentemente também foi constatado que o PPARy possui um sítio de ligação alternativo e que este não é bloqueado pelos antagonistas T0070907 e GW9662 (232).

No presente estudo, mesmo sendo um agonista parcial de RXRa, o dilaurato de DBT não foi capaz de induzir diferenciação quando o tratamento foi realizado juntamente com o antagonista T0070907. Este resultado pode ser explicado pelo fato do dilaurato de DBT ser um ligante com atividade agonista em RXRa dez vezes menor que o cloreto de TBT.

O PPARY é o principal regulador da adipogênese, com sua ativação estando igualmente relacionada com efeitos anti-inflamatórios $(54,228)$. Considerando-se que neste estudo, tanto o cloreto de TBT quanto os DBTs se comportaram como agonistas parciais deste receptor, também foram investigados os efeitos desses compostos na expressão de genes associados à resposta inflamatória.

No presente estudo, em células 3T3-L1, assim como a rosiglitazona, o cloreto de TBT reprimiu fortemente a expressão dos genes Dcn, Fn1 e Vcam1. O dicloreto, o dilaurato e o maleato de DBT também causaram supressão significativa destes genes inflamatórios, porém de maneira menos intensa. Já no outro tipo celular avaliado, em RAW 264.7 (macrófagos de camundongos), o cloreto de TBT inibiu moderadamente a expressão do TNFa e, dentre os DBTs, somente o dilaurato de DBT provocou esta mesma resposta. Também era esperado que a rosiglitazona reprimisse o TNFa, pois já se encontra bem relatado na literatura que as TZDs diminuem a expressão deste marcador inflamatório (110). Acredita-se que este efeito teria sido observado se a concentração utilizada de rosiglitazona $\left(10^{-5} \mathrm{M}\right)$ e/ou o tempo de tratamento fossem ajustados.

Embora em um contexto diferente, os efeitos de organoestânicos sobre a resposta inflamatória já foi investigado anteriormente. A exposição ao cloreto de TBT provocou alterações de vias de sinalização celulares essenciais para o funcionamento de linfócitos humanos (233), além de ter induzido a apoptose de 
neutrófilos (234). Em outro estudo, o DBT reduziu a atividade de linfócitos humanos, o que foi constatado tanto pela diminuição dos níveis de ATP, como da capacidade dos mesmos em lisar células tumorais (192).

De forma similar ao presente estudo, Nakamuta e colaboradores mostraram que em células RAW 264.7 estimuladas com LPS e tratadas com BADGE (um DE que atua como agonista de PPARy nesta linhagem celular), houve uma diminuição da expressão de TNFa (230). Desta forma, sugere-se que os efeitos dos butilestanhos sobre a expressão dos genes inflamatórios também possam ser mediados pelo PPARy.

Não se sabe se estes resultados baseados em ensaios celulares reproduzemse in vivo, mas há alguns poucos estudos que avaliaram os efeitos de compostos organoestânicos em animais.

O estudo de Zuo e colaboradores mostrou que a exposição crônica e repetida ao cloreto de TBT provocou em camundongos, além do ganho de peso, esteatose hepática, hiperinsulinemia, hiperleptinemia e redução dos níveis plasmáticos de adiponectina (23). Outro trabalho de Grun e colaboradores observou que o tratamento de camundongos adultos com cloreto de TBT, por apenas 24 horas, provocou aumento na expressão de genes adipogênicos no tecido adiposo epididimal e no fígado. Esse mesmo estudo ainda mostrou que o contato com este composto durante o período intra-uterino resultou em: (i) aumento da adiposidade nos testículos, no fígado e no tecido adiposo inguinal de camundongos neonatos e (ii) aumento da massa do tecido adiposo epididimal de camundongos adultos (22). Adicionalmente, Penza e colaboradores também relataram que camundongos adultos expostos ao cloreto de TBT tiveram aumento da massa do tecido adiposo, porém sem apresentarem alterações no peso corporal total, na sensibilidade à insulina e na tolerância à glicose (180).

A obesidade e a esteatose hepática em roedores são manifestações que são esperadas quando o PPARy é ativado por agonistas, como é o caso do cloreto de TBT (235). Entretanto, o aumento da massa do tecido adiposo visceral assim como a hiperinsulinemia são efeitos que não condizem com a ativação do PPARY, uma vez que agonistas desse receptor apresentam efeito benéfico sobre a sensibilidade insulínica (236). Todos esses resultados indicam serem necessários mais estudos para a compreensão dos mecanismos pelos quais um agonista de PPARY e/ou $\mathrm{RXR} \alpha$ poderia provocar essas alterações. 


\section{CONCLUSÃO}

Nossos resultados mostraram que o diacetato, o dicloreto, o dilaurato e o maleato de DBT são agonistas parciais do PPARy e que o dicloreto e o dilaurato de DBT também são agonistas parciais do RXRa. Até onde se sabe, esses efeitos ainda não haviam sido relatados. Além disso, o cloreto de TBT e os compostos de DBT avaliados promoveram a adipogênese e reprimiram genes associados à resposta inflamatória em cultura de células de mamíferos.

Embora a transferência de resultados baseados em ensaios celulares para os efeitos in vivo tenha limitações, estes achados abrem novos caminhos para melhor compreensão de como os compostos organoestânicos podem afetar a saúde humana.

No entanto, novos estudos são necessários para investigar outros alvos farmacológicos, diferenças nos efeitos de acordo com o período da vida em que a exposição ocorreu e também as complexas ações destes organoestânicos no contexto do organismo como um todo. 


\section{REFERÊNCIAS BIBLIOGRÁFICAS}

1. Colborn T, vom Saal FS, Soto AM. Developmental effects of endocrinedisrupting chemicals in wildlife and humans. Environmental Health Perspectives. 1993;101(5):378-84.

2. Neel BA, Sargis RM. The Paradox of Progress: Environmental Disruption of Metabolism and the Diabetes Epidemic. Diabetes. 2011;60(7):1838-48.

3. Grün F, Blumberg B. Perturbed nuclear receptor signaling by environmental obesogens as emerging factors in the obesity crisis. Reviews in Endocrine and Metabolic Disorders. 2007;8(2):161-71.

4. Vasseur $P$, Cossu-Leguille $C$. Linking molecular interactions to consequent effects of persistent organic pollutants (POPs) upon populations. Chemosphere. 2006;62(7):1033-42.

5. Diamanti-Kandarakis E, Bourguignon J-P, Giudice LC, Hauser R, Prins GS, Soto AM, et al. Endocrine-Disrupting Chemicals: An Endocrine Society Scientific Statement. Endocrine Reviews. 2009;30(4):293-342.

6. Delfosse V, Maire Al, Balaguer P, Bourguet W. A structural perspective on nuclear receptors as targets of environmental compounds. Acta Pharmacol Sin. 2015;36(1):88-101.

7. Grün F, Blumberg B. Environmental Obesogens: Organotins and Endocrine Disruption via Nuclear Receptor Signaling. Endocrinology. 2006;147(6):s50-s5.

8. Janesick A, Blumberg B. Endocrine Disrupting Chemicals and the Developmental Programming of Adipogenesis and Obesity. Birth defects research Part C, Embryo today : reviews. 2011;93(1):34-50.

9. Baillie-Hamilton PF. Chemical Toxins: A Hypothesis to Explain the Global Obesity Epidemic. The Journal of Alternative and Complementary Medicine. 2002;8(2):185-92.

10. Alonso-Magdalena P, Vieira E, Soriano S, Menes L, Burks D, Quesada I, et al. Bisphenol A Exposure during Pregnancy Disrupts Glucose Homeostasis in Mothers and Adult Male Offspring. Environmental Health Perspectives. 2010;118(9):1243-50.

11. Ruzzin J, Petersen R, Meugnier E, Madsen L, Lock E-J, Lillefosse H, et al. Persistent Organic Pollutant Exposure Leads to Insulin Resistance Syndrome. Environmental Health Perspectives. 2010;118(4):465-71. 
12. Lim J-S, Lee D-H, Jacobs DR. Association of Brominated Flame Retardants With Diabetes and Metabolic Syndrome in the U.S. Population, 2003-2004. Diabetes Care. 2008;31(9):1802-7.

13. Ukropec J, Radikova Z, Huckova M, Koska J, Kocan A, Sebokova E, et al. High prevalence of prediabetes and diabetes in a population exposed to high levels of an organochlorine cocktail. Diabetologia. 2010;53(5):899-906.

14. Lee D-H, Steffes MW, Sjödin A, Jones RS, Needham LL, Jacobs DR. Low Dose Organochlorine Pesticides and Polychlorinated Biphenyls Predict Obesity, Dyslipidemia, and Insulin Resistance among People Free of Diabetes. PLoS ONE. 2011;6(1):e15977.

15. Pereira-Fernandes A, Vanparys C, Hectors TLM, Vergauwen L, Knapen D, Jorens PG, et al. Unraveling the mode of action of an obesogen: Mechanistic analysis of the model obesogen tributyltin in the 3T3-L1 cell line. Molecular and Cellular Endocrinology. 2013;370(1-2):52-64.

16. Fent K. Ecotoxicology of Organotin Compounds. Critical Reviews in Toxicology. 1996;26(1):3-117.

17. Brown J. IMO Tributyltin ban - International's position. Propeller Direct. $2000 ; 7(1): 1-16$.

18. Gipperth L. The legal design of the international and European Union ban on tributyltin antifouling paint: Direct and indirect effects. Journal of Environmental Management. 2009;90, Supplement 1:S86-S95.

19. CLH. Report for Tributyltin Compounds. Dortmund - Germany, Health BFIfOSa; 2013 April.

20. Kirchner S, Kieu T, Chow C, Casey S, Blumberg B. Prenatal Exposure to the Environmental Obesogen Tributyltin Predisposes Multipotent Stem Cells to Become Adipocytes. Molecular Endocrinology. 2010;24(3):526-39.

21. Li X, Ycaza J, Blumberg B. The environmental obesogen tributyltin chloride acts via peroxisome proliferator activated receptor gamma to induce adipogenesis in murine 3T3-L1 preadipocytes. The Journal of Steroid Biochemistry and Molecular Biology. 2011;127(1-2):9-15.

22. Grün F, Watanabe H, Zamanian Z, Maeda L, Arima K, Cubacha R, et al. Endocrine-Disrupting Organotin Compounds Are Potent Inducers of Adipogenesis in Vertebrates. Molecular Endocrinology. 2006;20(9):2141-55. 
23. Zuo Z, Chen S, Wu T, Zhang J, Su Y, Chen Y, et al. Tributyltin causes obesity and hepatic steatosis in male mice. Environmental toxicology. 2009;26(1):79-85.

24. Hoch M. Organotin compounds in the environment - an overview. Applied Geochemistry. 2001;16(7-8):719-43.

25. Piver WT. Organotin compounds: industrial applications and biological investigation. Environmental Health Perspectives. 1973;4:61-79.

26. WHO. Dialkyltins in Drinking-water - Background document for development of WHO Guidelines for Drinking-water Quality. World Health Organization - WHO. 2004. 27. Nwaogu TA, Zarogiannis P, Tuffnell N, Floyd P. Impact Assessment of Potential Restrictions on the Marketing and Use of Certain Organotin Compounds. Loddon: European Commission Directorate - General Enterprise and Industry; 2007. 28. Ueno S, Kashimoto T, Susa N, Shiota Y, Okuda M, Mutoh K-i, et al. Effects of butyltin compounds on mitochondrial respiration and its relation to hepatotoxicity in mice and guinea pigs. Toxicological Sciences. 2003;75(1):201-7.

29. Whalen MM, Loganathan BG, Kannan K. Immunotoxicity of Environmentally Relevant Concentrations of Butyltins on Human Natural Killer Cells in Vitro. Environmental Research. 1999;81(2):108-16.

30. Jenkins SM, Ehman K, Barone Jr S. Structure-activity comparison of organotin species: dibutyltin is a developmental neurotoxicant in vitro and in vivo. Developmental Brain Research. 2004;151(1-2):1-12.

31. Laudet V. Evolution of the nuclear receptor superfamily: early diversification from an ancestral orphan receptor. Journal of Molecular Endocrinology. 1997;19(3):207-26.

32. Robinson-Rechavi M, Garcia HE, Laudet V. The nuclear receptor superfamily. Journal of Cell Science. 2003;116(4):585-6.

33. Aranda A, Pascual A. Nuclear Hormone Receptors and Gene Expression. Physiological Reviews. 2001;81(3):1269-304.

34. Olefsky JM. Nuclear Receptor Minireview Series. Journal of Biological Chemistry. 2001;276(40):36863-4.

35. Choi J-M, Bothwell ALM. The Nuclear Receptor PPARs as Important Regulators of T-Cell Functions and Autoimmune Diseases. Molecules and Cells. 2012;33(3):217-22.

36. Sonoda J, Pei L, Evans RM. Nuclear Receptors: Decoding Metabolic Disease. FEBS letters. 2008;582(1):2-9. 
37. Nagy L, Schwabe JWR. Mechanism of the nuclear receptor molecular switch. Trends in Biochemical Sciences. 2004;29(6):317-24.

38. Nuclear Receptors Nomenclature. A Unified Nomenclature System for the Nuclear Receptor Superfamily. Cell. 1999;97(2):161-3.

39. Evans RM, Barish GD, Wang Y-X. PPARs and the complex journey to obesity. Nat Med. 2004;10(4):355-61.

40. Michalik L, Auwerx J, Berger JP, Chatterjee VK, Glass CK, Gonzalez FJ, et al. International Union of Pharmacology. LXI. Peroxisome Proliferator-Activated Receptors. Pharmacological Reviews. 2006;58(4):726-41.

41. Issemann I, Green S. Activation of a member of the steroid hormone receptor superfamily by peroxisome proliferators. Nature. 1990;347(6294):645-50.

42. Kliewer SA, Forman BM, Blumberg B, Ong ES, Borgmeyer U, Mangelsdorf DJ, et al. Differential expression and activation of a family of murine peroxisome proliferator-activated receptors. Proceedings of the National Academy of Sciences of the United States of America. 1994;91(15):7355-9.

43. Braissant O, Foufelle F, Scotto C, Dauca M, Wahli W. Differential expression of peroxisome proliferator-activated receptors (PPARs): tissue distribution of PPARalpha, -beta, and -gamma in the adult rat. Endocrinology. 1996;137(1):354-66.

44. Lefebvre P, Chinetti G, Fruchart J-C, Staels B. Sorting out the roles of PPARa in energy metabolism and vascular homeostasis. Journal of Clinical Investigation. 2006;116(3):571-80.

45. Dreyer C, Krey G, Keller H, Givel F, Helftenbein G, Wahli W. Control of the peroxisomal beta-oxidation pathway by a novel family of nuclear hormone receptors. Cell. 1992;68(5):879-87.

46. Ehrenborg E, Krook A. Regulation of Skeletal Muscle Physiology and Metabolism by Peroxisome Proliferator-Activated Receptor $\delta$. Pharmacological Reviews. 2009;61(3):373-93.

47. Ahmadian M, Suh JM, Hah N, Liddle C, Atkins AR, Downes $M$, et al. PPAR[gamma] signaling and metabolism: the good, the bad and the future. Nat Med. 2013;99(5):557-66.

48. Zoete V, Grosdidier A, Michielin O. Peroxisome proliferator-activated receptor structures: Ligand specificity, molecular switch and interactions with regulators. Biochimica et Biophysica Acta (BBA) - Molecular and Cell Biology of Lipids. 2007;1771(8):915-25. 
49. Juge-Aubry C, Pernin A, Favez T, Burger AG, Wahli W, Meier CA, et al. DNA Binding Properties of Peroxisome Proliferator-activated Receptor Subtypes on Various Natural Peroxisome Proliferator Response Elements: IMPORTANCE OF THE 5'-FLANKING REGION. Journal of Biological Chemistry. 1997;272(40):25252-9. 50. Neels JG, Grimaldi PA. Physiological Functions of Peroxisome ProliferatorActivated Receptor $\beta$. Physiological Reviews. 2014;94(3):795-858.

51. Rosenfeld MG, Lunyak VV, Glass CK. Sensors and signals: a coactivator/corepressor/epigenetic code for integrating signal-dependent programs of transcriptional response. Genes \& Development. 2006;20(11):1405-28.

52. Glass CK, Rosenfeld MG. The coregulator exchange in transcriptional functions of nuclear receptors. Genes \& Development. 2000;14(2):121-41.

53. Dilworth FJ, Chambon P. Nuclear receptors coordinate the activities of chromatin remodeling complexes and coactivators to facilitate initiation of transcription. Oncogene. 2001;20:3047-54.

54. Ricote M, Glass CK. PPARs and molecular mechanisms of transrepression. Biochimica et biophysica acta. 2007;1771(8):926-35.

55. Delerive P, De Bosscher K, Besnard S, Vanden Berghe W, Peters JM, Gonzalez FJ, et al. Peroxisome Proliferator-activated Receptor a Negatively Regulates the Vascular Inflammatory Gene Response by Negative Cross-talk with Transcription Factors NF-kB and AP-1. Journal of Biological Chemistry. 1999;274(45):32048-54.

56. Li M, Pascual G, Glass CK. Peroxisome Proliferator-Activated Receptor YDependent Repression of the Inducible Nitric Oxide Synthase Gene. Molecular and Cellular Biology. 2000;20(13):4699-707.

57. Pascual G, Fong AL, Ogawa S, Gamliel A, Li AC, Perissi V, et al. A sumoylation-dependent pathway mediating transrepression of inflammatory response genes by PPARy. Nature. 2005;437(7059):759-63.

58. Ghisletti S, Huang W, Ogawa S, Pascual G, Lin M-E, Willson TM, et al. Parallel SUMOylation-dependent pathways mediate gene- and signal-specific transrepression by LXRs and PPARY. Molecular cell. 2007;25(1):57-70.

59. Zieleniak A, Wójcik M, Woźniak LA. Structure and physiological functions of the human peroxisome proliferator-activated receptor $\gamma$. Archivum Immunologiae et Therapiae Experimentalis. 2008;56(5):331. 
60. Kliewer SA, Sundseth SS, Jones SA, Brown PJ, Wisely GB, Koble CS, et al. Fatty acids and eicosanoids regulate gene expression through direct interactions with peroxisome proliferator-activated receptors $\alpha$ and $\mathrm{y}$. Proceedings of the National Academy of Sciences of the United States of America. 1997;94(9):4318-23.

61. Forman BM, Tontonoz P, Chen J, Brun RP, Spiegelman BM, Evans RM. 15Deoxy-12-14-Prostaglandin $\mathrm{J} 2$ is a ligand for the adipocyte determination factor PPARy. Cell. 1995;83(5):803-12.

62. Nagy L, Tontonoz P, Alvarez JGA, Chen H, Evans RM. Oxidized LDL Regulates Macrophage Gene Expression through Ligand Activation of PPAR\&\#x3b3. Cell. 1998;93(2):229-40.

63. Lehmann JM, Moore LB, Smith-Oliver TA, Wilkison WO, Willson TM, Kliewer SA. An Antidiabetic Thiazolidinedione Is a High Affinity Ligand for Peroxisome Proliferator-activated Receptor Y (PPARY). Journal of Biological Chemistry. 1995;270(22):12953-6.

64. Spiegelman BM. PPAR-gamma: adipogenic regulator and thiazolidinedione receptor. Diabetes. 1998;47(4):507-14.

65. Rosen ED, Spiegelman BM. PPARY: a Nuclear Regulator of Metabolism, Differentiation, and Cell Growth. Journal of Biological Chemistry. 2001;276(41):37731-4.

66. Waku T, Shiraki T, Oyama T, Fujimoto Y, Maebara K, Kamiya N, et al. Structural Insight into PPARY Activation Through Covalent Modification with Endogenous Fatty Acids. Journal of Molecular Biology. 2009;385(1):188-99.

67. Shiraki T, Kamiya N, Shiki S, Kodama TS, Kakizuka A, Jingami H. $\alpha, \beta-$ Unsaturated Ketone Is a Core Moiety of Natural Ligands for Covalent Binding to Peroxisome Proliferator-activated Receptor $\mathrm{Y}$. Journal of Biological Chemistry. 2005;280(14):14145-53.

68. Waku T, Shiraki T, Oyama T, Morikawa K. Atomic structure of mutant PPARgamma LBD complexed with 15d-PGJ2: Novel modulation mechanism of PPARgamma/RXRalpha function by covalently bound ligands. Journal of Molecular Biology. 2009;583:320-4.

69. Leesnitzer LM, Parks DJ, Bledsoe RK, Cobb JE, Collins JL, Consler TG, et al. Functional Consequences of Cysteine Modification in the Ligand Binding Sites of Peroxisome Proliferator Activated Receptors by GW9662. Biochemistry. 2002;41(21):6640-50. 
70. Amato AA, Rajagopalan S, Lin JZ, Carvalho BM, Figueira ACM, Lu J, et al. GQ-16, a Novel Peroxisome Proliferator-activated Receptor y (PPARY) Ligand, Promotes Insulin Sensitization without Weight Gain. Journal of Biological Chemistry. 2012;287(33):28169-79.

71. Harada S, Hiromori Y, Nakamura S, Kawahara K, Fukakusa S, Maruno T, et al. Structural basis for PPARy transactivation by endocrine-disrupting organotin compounds. Scientific Reports. 2015;5:8520.

72. Chawla A, Schwarz EJ, Dimaculangan DD, Lazar MA. Peroxisome proliferator-activated receptor (PPAR) gamma: adipose-predominant expression and induction early in adipocyte differentiation. Endocrinology. 1994;135(2):798-800.

73. Tontonoz $\mathrm{P}, \mathrm{Hu}$ E, Spiegelman BM. Stimulation of adipogenesis in fibroblasts by PPAR gamma 2, a lipid-activated transcription factor. Cell. 1994;79(7):1147-56.

74. Wu Z, Rosen ED, Brun R, Hauser S, Adelmant G, Troy AE, et al. CrossRegulation of C/EBPalpha and PPARgamma Controls the Transcriptional Pathway of Adipogenesis and Insulin Sensitivity. Molecular Cell. 1999;3(2):151-8.

75. Wu Z, Bucher NL, Farmer SR. Induction of peroxisome proliferator-activated receptor gamma during the conversion of 3T3 fibroblasts into adipocytes is mediated by C/EBPbeta, C/EBPdelta, and glucocorticoids. Molecular and Cellular Biology. 1996;16(8):4128-36.

76. Darlington GJ, Ross SE, MacDougald OA. The Role of C/EBP Genes in Adipocyte Differentiation. Journal of Biological Chemistry. 1998;273(46):30057-60.

77. Lefterova MI, Zhang Y, Steger DJ, Schupp M, Schug J, Cristancho A, et al. PPARY and C/EBP factors orchestrate adipocyte biology via adjacent binding on a genome-wide scale. Genes \& Development. 2008;22(21):2941-52.

78. Sfeir Z, Ibrahimi A, Amri E, Grimaldi P, Abumrad N. Regulation of FAT/CD36 gene expression: further evidence in support of a role of the protein in fatty acid binding/transport. Prostaglandins, Leukotrienes and Essential Fatty Acids. 1997;57(1):17-21.

79. Bernlohr DA, Angus CW, Lane MD, Bolanowski MA, Kelly TJ. Expression of specific mRNAs during adipose differentiation: identification of an mRNA encoding a homologue of myelin P2 protein. Proceedings of the National Academy of Sciences of the United States of America. 1984;81(17):5468-72. 
80. Greenberg AS, Egan JJ, Wek SA, Moos MC, Londos C, Kimmel AR. Isolation of cDNAs for perilipins $A$ and $B$ : sequence and expression of lipid droplet-associated proteins of adipocytes. Proceedings of the National Academy of Sciences of the United States of America. 1993;90(24):12035-9.

81. Paulauskis JD, Sul HS. Cloning and expression of mouse fatty acid synthase and other specific mRNAs. Developmental and hormonal regulation in 3T3-L1 cells. Journal of Biological Chemistry. 1988;263(15):7049-54.

82. Weiner FR, Smith PJ, Wertheimer S, Rubin CS. Regulation of gene expression by insulin and tumor necrosis factor alpha in 3T3-L1 cells. Modulation of the transcription of genes encoding acyl-CoA synthetase and stearoyl-CoA desaturase-1. Journal of Biological Chemistry. 1991;266(35):23525-8.

83. Wu Z, Xie Y, Morrison RF, Bucher NL, Farmer SR. PPARgamma induces the insulin-dependent glucose transporter GLUT4 in the absence of C/EBPalpha during the conversion of 3T3 fibroblasts into adipocytes. Journal of Clinical Investigation. 1998;101(1):22-32.

84. Gray S, Feinberg MW, Hull S, Kuo CT, Watanabe M, SS, et al. The Krüppellike Factor KLF15 Regulates the Insulin-sensitive Glucose Transporter GLUT4. Journal of Biological Chemistry. 2002;277(37):34322-8.

85. Hu E, Tontonoz P, Spiegelman BM. Transdifferentiation of myoblasts by the adipogenic transcription factors PPAR gamma and C/EBP alpha. Proceedings of the National Academy of Sciences of the United States of America. 1995;92(21):985660.

86. Barak Y, Nelson MC, Ong ES, Jones YZ, Ruiz-Lozano P, Chien KR, et al. PPARgamma; Is Required for Placental, Cardiac, and Adipose Tissue Development. Molecular Cell. 1999;4(4):585-95.

87. Agarwal AK, Garg A. A Novel Heterozygous Mutation in Peroxisome Proliferator-Activated Receptor- $\gamma$ Gene in a Patient with Familial Partial Lipodystrophy. The Journal of Clinical Endocrinology \& Metabolism. 2002;87(1):408-. 88. Jeninga EH, Beekum Ov, Dijk ADJv, Hamers N, Hendriks-Stegeman BI, Bonvin AMJJ, et al. Impaired Peroxisome Proliferator-Activated Receptor y Function through Mutation of a Conserved Salt Bridge (R425C) in Familial Partial Lipodystrophy. Molecular Endocrinology. 2007;21(5):1049-65.

89. Kershaw EE, Flier JS. Adipose Tissue as an Endocrine Organ. The Journal of Clinical Endocrinology \& Metabolism. 2004;89(6):2548-56. 
90. Scherer PE. Adipose Tissue. From Lipid Storage Compartment to Endocrine Organ. 2006;55(6):1537-45.

91. Cook K, Min H, Johnson D, Chaplinsky R, Flier J, Hunt C, et al. Adipsin: a circulating serine protease homolog secreted by adipose tissue and sciatic nerve. Science. 1987;237(4813):402-5.

92. Zhang Y, Proenca R, Maffei M, Barone M, Leopold L, Friedman JM. Positional cloning of the mouse obese gene and its human homologue. Nature. 1994;372(6505):425-32.

93. Lago F, Dieguez C, Gómez-Reino J, Gualillo O. The emerging role of adipokines as mediators of inflammation and immune responses. Cytokine and Growth Factor Reviews. 2007;18(3):313-25.

94. Hu E, Liang P, Spiegelman BM. AdipoQ Is a Novel Adipose-specific Gene Dysregulated in Obesity. Journal of Biological Chemistry. 1996;271(18):10697-703.

95. Yang W-S, Jeng C-Y, Wu T-J, Tanaka S, Funahashi T, Matsuzawa Y, et al. Synthetic Peroxisome Proliferator-Activated Receptor-y Agonist, Rosiglitazone, Increases Plasma Levels of Adiponectin in Type 2 Diabetic Patients. Diabetes Care. 2002;25(2):376-80.

96. Rajala MW, Obici S, Scherer PE, Rossetti L. Adipose-derived resistin and gutderived resistin-like molecule- $\beta$ selectively impair insulin action on glucose production. Journal of Clinical Investigation. 2003;111(2):225-30.

97. Hotamisligil G, Shargill N, Spiegelman B. Adipose expression of tumor necrosis factor-alpha: direct role in obesity-linked insulin resistance. Science. 1993;259(5091):87-91.

98. Fain JN, Madan AK, Hiler ML, Cheema P, Bahouth SW. Comparison of the Release of Adipokines by Adipose Tissue, Adipose Tissue Matrix, and Adipocytes from Visceral and Subcutaneous Abdominal Adipose Tissues of Obese Humans. Endocrinology. 2004;145(5):2273-82.

99. Stephens JM, Lee J, Pilch PF. Tumor Necrosis Factor-a-induced Insulin Resistance in 3T3-L1 Adipocytes Is Accompanied by a Loss of Insulin Receptor Substrate-1 and GLUT4 Expression without a Loss of Insulin Receptor-mediated Signal Transduction. Journal of Biological Chemistry. 1997;272(2):971-6.

100. Senn JJ, Klover PJ, Nowak IA, Mooney RA. Interleukin-6 Induces Cellular Insulin Resistance in Hepatocytes. Diabetes. 2002;51(12):3391-9. 
101. Moller DE, Flier JS. Insulin Resistance - Mechanisms, Syndromes, and Implications. New England Journal of Medicine. 1991;325(13):938-48.

102. Ye JM, Dzamko N, Cleasby ME, Hegarty BD, Furler SM, Cooney GJ, et al. Direct demonstration of lipid sequestration as a mechanism by which rosiglitazone prevents fatty-acid-induced insulin resistance in the rat: comparison with metformin. Diabetologia. 2004;47(7):1306-13.

103. Okuno A, Tamemoto H, Tobe K, Ueki K, Mori Y, Iwamoto K, et al. Troglitazone increases the number of small adipocytes without the change of white adipose tissue mass in obese Zucker rats. Journal of Clinical Investigation. 1998;101(6):1354-61.

104. Semple RK, Chatterjee VKK, O'Rahilly S. PPARY and human metabolic disease. Journal of Clinical Investigation. 2006;116(3):581-9.

105. Kelly IE, Han TS, Walsh K, Lean ME. Effects of a thiazolidinedione compound on body fat and fat distribution of patients with type 2 diabetes. Diabetes Care. 1999;22(2):288-93.

106. Mori Y, Murakawa Y, Okada K, Horikoshi H, Yokoyama J, Tajima N, et al. Effect of troglitazone on body fat distribution in type 2 diabetic patients. Diabetes Care. 1999;22(6):908-12.

107. Ibrahimi MM. Subcutaneous and visceral adipose tissue: structural and functional differences. Obesity Reviews. 2010;11(1):11-8.

108. Choi JH, Banks AS, Estall JL, Kajimura S, Bostrom P, Laznik D, et al. Antidiabetic drugs inhibit obesity-linked phosphorylation of PPAR[ggr] by Cdk5. Nature. 2010;466(7305):451-6.

109. Duval C, Chinetti G, Trottein F, Fruchart J-C, Staels B. The role of PPARs in atherosclerosis. Trends in Molecular Medicine. 2002;8(9):422-30.

110. Jiang C, Ting AT, Seed B. PPAR-[gamma] agonists inhibit production of monocyte inflammatory cytokines. Nature. 1998;391(6662):82-6.

111. Ricote M, Li AC, Willson TM, Kelly CJ, Glass CK. The peroxisome proliferatoractivated receptor-[gamma] is a negative regulator of macrophage activation. Nature. 1998;391(6662):79-82.

112. Phillips LS, Grunberger G, Miller E, Patwardhan R, Rappaport EB, Salzman A. Once- and Twice-Daily Dosing With Rosiglitazone Improves Glycemic Control in Patients With Type 2 Diabetes. Diabetes Care. 2001;24(2):308-15. 
113. Mayerson AB, Hundal RS, Dufour S, Lebon V, Befroy D, Cline GW, et al. The effects of rosiglitazone on insulin sensitivity, lipolysis, and hepatic and skeletal muscle triglyceride content in patients with type 2 diabetes. Diabetes. 2002;51(3):797-802.

114. ANVISA. CARTA CIRCULAR No. 08 - GFARM/NUVIG/ANVISA/MS. Assunto: Cancelamento de registro do medicamento Avandia ${ }^{\circledR}$ (rosiglitazona). Agência Nacional de Vigilância Sanitária. 2010.

115. European Medicines Agency. European Medicines Agency recommends suspension of Avandia, Avandamet and Avaglim: Anti-diabetes medication to be taken off the market. European Medicines Agency. 2010.

116. Faillie J-L, Petit P, Montastruc J-L, Hillaire-Buys D. Scientific Evidence and Controversies About Pioglitazone and Bladder Cancer: Which Lessons Can Be Drawn? Drug Safety. 2013;36(9):693-707.

117. FDA. Safety Alerts for Human Medical Products: Rosiglitazone-containing Diabetes Medicines/ Drug Safety Communication - FDA Eliminates the Risk $\begin{array}{llll}\text { Evaluation and } \quad \text { Mitigation } & \text { Strategy }\end{array}$ http://www.fda.gov/Safety/MedWatch/Safetylnformation/SafetyAlertsforHumanMedic alProducts/ucm477601.htm. U S Food and Drug Administration - FDA. 2015.

118. Nissen SE, Wolski K. Effect of Rosiglitazone on the Risk of Myocardial Infarction and Death from Cardiovascular Causes. New England Journal of Medicine. 2007;356(24):2457-71.

119. Grey A, Bolland M, Gamble G, Wattie D, Horne A, Davidson J, et al. The Peroxisome Proliferator-Activated Receptor-y Agonist Rosiglitazone Decreases Bone Formation and Bone Mineral Density in Healthy Postmenopausal Women: A Randomized, Controlled Trial. The Journal of Clinical Endocrinology \& Metabolism. 2007;92(4):1305-10.

120. Ahmed LA, Joakimsen RM, Berntsen GK, Fønnebø V, Schirmer H. Diabetes mellitus and the risk of non-vertebral fractures: the Troms $\varnothing$ study. Osteoporosis International. 2006;17(4):495-500.

121. Janghorbani M, Van Dam RM, Willett WC, Hu FB. Systematic Review of Type 1 and Type 2 Diabetes Mellitus and Risk of Fracture. American Journal of Epidemiology. 2007;166(5):495-505. 
122. Vestergaard P, Rejnmark L, Mosekilde L. Diabetes and Its Complications and Their Relationship with Risk of Fractures in Type 1 and 2 Diabetes. Calcified Tissue International. 2008;84(1):45.

123. Yan W, Li X. Impact of diabetes and its treatments on skeletal diseases. Frontiers of Medicine. 2013;7(1):81-90.

124. Schwartz AV, Sellmeyer DE, Vittinghoff E, Palermo L, Lecka-Czernik B, Feingold KR, et al. Thiazolidinedione (TZD) Use and Bone Loss in Older Diabetic Adults. The Journal of clinical endocrinology and metabolism. 2006;91(9):3349-54.

125. Akune T, Ohba S, Kamekura S, Yamaguchi M, Chung U-i, Kubota N, et al. PPAR $y$ insufficiency enhances osteogenesis through osteoblast formation from bone marrow progenitors. Journal of Clinical Investigation. 2004;113(6):846-55.

126. Lazarenko OP, Rzonca SO, Suva LJ, Lecka-Czernik B. Netoglitazone is a PPAR-gamma ligand with selective effects on bone and fat. Bone. 2006;38(1):74-84.

127. Burgermeister E, Schnoebelen A, Flament A, Benz J, Stihle M, Gsell B, et al. A Novel Partial Agonist of Peroxisome Proliferator-Activated Receptor-y (PPARY) Recruits PPARy-Coactivator-1a, Prevents Triglyceride Accumulation, and Potentiates Insulin Signaling in Vitro. Molecular Endocrinology. 2006;20(4):809-30.

128. Bruning JB, Chalmers MJ, Prasad S, Busby SA, Kamenecka TM, He Y, et al. Partial Agonists Activate PPAR gamma Using a Helix 12 Independent Mechanism. Structure. 2007;15(10):1258-71.

129. Jones KC, de Voogt P. Persistent organic pollutants (POPs): state of the science. Environmental Pollution. 1999;100(1-3):209-21.

130. EPA. What is Endocrine Disruption? https://www.epa.gov/endocrine-disruption (accessed Nov. 16, 2016). In: Agency USEP, editor.: United States Environmental Protection Agency; 2016.

131. Elobeid MA, Allison DB. Putative Environmental-Endocrine Disruptors and Obesity: A Review. Current opinion in endocrinology, diabetes, and obesity. 2008;15(5):403-8.

132. De Coster S, van Larebeke N. Endocrine-Disrupting Chemicals: Associated Disorders and Mechanisms of Action. Journal of Environmental and Public Health. 2012;2012:52.

133. Kabir ER, Rahman MS, Rahman I. A review on endocrine disruptors and their possible impacts on human health. Environmental Toxicology and Pharmacology. 2015;40(1):241-58. 
134. Laitman CJ. DES exposure and the aging woman: mothers and daughters. Current women's health reports. 2002;2(5):390-3.

135. Maffini MV, Rubin BS, Sonnenschein C, Soto AM. Endocrine disruptors and reproductive health: The case of bisphenol-A. Molecular and Cellular Endocrinology. 2006;254-255:179-86.

136. Masuno H, Kidani T, Sekiya K, Sakayama K, Shiosaka T, Yamamoto H, et al. Bisphenol $A$ in combination with insulin can accelerate the conversion of 3T3-L1 fibroblasts to adipocytes. Journal of Lipid Research. 2002;43(5):676-84.

137. Rubin BS, Murray MK, Damassa DA, King JC, Soto AM. Perinatal exposure to low doses of bisphenol A affects body weight, patterns of estrous cyclicity, and plasma LH levels. Environmental Health Perspectives. 2001;109(7):675-80.

138. Li D-K, Miao M, Zhou Z, Wu C, Shi H, Liu X, et al. Urine Bisphenol-A Level in Relation to Obesity and Overweight in School-Age Children. PLoS ONE. 2013;8(6):e65399.

139. Heudorf U, Mersch-Sundermann V, Angerer J. Phthalates: Toxicology and exposure. International Journal of Hygiene and Environmental Health. 2007;210(5):623-34.

140. Stahlhut RW, van Wijngaarden E, Dye TD, Cook S, Swan SH. Concentrations of Urinary Phthalate Metabolites Are Associated with Increased Waist Circumference and Insulin Resistance in Adult U.S. Males. Environmental Health Perspectives. 2007;115(6):876-82.

141. WHO. Obesity and overweight. http://www.who.int/mediacentre/factsheets/fs311/en/ (accessed Nov. 3, 2016). World Health Organization - WHO. 2016.

142. Abelson P, Kennedy D. The Obesity Epidemic. Science. 2004;304(5676):1413-.

143. Haslam DW, James WPT. Obesity. The Lancet. 2005;366(9492):1197-209.

144. Grundy SM. Multifactorial causation of obesity: implications for prevention. The American Journal of Clinical Nutrition. 1998;67(3):563S-72S.

145. Wells JCK, Siervo M. Obesity and energy balance: is the tail wagging the dog? Eur J Clin Nutr. 2011;65(11):1173-89. 
146. Kim M-J, Marchand P, Henegar C, Antignac J-P, Alili R, Poitou C, et al. Fate and Complex Pathogenic Effects of Dioxins and Polychlorinated Biphenyls in Obese Subjects before and after Drastic Weight Loss. Environmental Health Perspectives. 2011;119(3):377-83.

147. Appel KE. Organotin Compounds: Toxicokinetic Aspects. Drug Metabolism Reviews. 2004;36(3-4):763-86.

148. Antizar-Ladislao B. Environmental levels, toxicity and human exposure to tributyltin (TBT)-contaminated marine environment. A review. Environment International. 2008;34(2):292-308.

149. Yngve V. Stabilized vinil resins. United States Patent Office. 1940.

150. Van der Kerk GJM, Luijten JGA. Investigation on organo-tin compounds. III.* The biocidal properties of organo-tin compounds Journal of Applied Chemistry. 1954:314-8.

151. Guérin T, Sirot V, Volatier JL, Leblanc JC. Organotin levels in seafood and its implications for health risk in high-seafood consumers. Science of The Total Environment. 2007;388(1-3):66-77.

152. Saxena AK. Organotin compounds: Toxicology and biomedicinal applications. Applied Organometallic Chemistry. 1987;1:39-56.

153. WHO. Organotins in Drinking-water - Draft background document for development of WHO Guidelines for Drinking-water Quality. World Health Organization - WHO. 2016.

154. Gumy C, Chandsawangbhuwana C, Dzyakanchuk AA, Kratschmar DV, Baker ME, Odermatt A. Dibutyltin Disrupts Glucocorticoid Receptor Function and Impairs Glucocorticoid-Induced Suppression of Cytokine Production. PLoS ONE. 2008;3(10):e3545.

155. PubChem Compound Database. Tributyltin chloride, CID=15096, https://pubchem.ncbi.nlm.nih.gov/compound/15096 (accessed Nov. 3, 2016). National Center for Biotechnology Information, Compound Database. 2016.

156. Maguire RJ, Chau YK, Bengert GA, Hale EJ, Wong PTS, Kramar O. Occurrence of organotin compounds in Ontario lakes and rivers. Environmental Science \& Technology. 1982;16(10):698-702.

157. Maguire RJ, Tkacz RJ, Chau YK, Bengert GA, Wong PTS. Occurrence of organotin compounds in water and sediment in Canada. Chemosphere. $1986 ; 15(3): 253-74$. 
158. Alzieu C, Heral M. Ecotoxicological effects of organotin compounds on oyster culture. In: Ecotoxicological Testing for the Marine Environment; G Persoone \& al(Eds), Ghent \& Inst Mar Scient Res, Belgium. 1984;2:187-96.

159. Alzieu CL, Sanjuan J, Deltreil JP, Borel M. Tin contamination in Arcachon Bay: Effects on oyster shell anomalies. Marine Pollution Bulletin. 1986;17(11):494-8.

160. Alzieu C, Sanjuan J, Michel P, Borel M, Dreno JP. Monitoring and Assessment of Butyltins in Atlantic Coastal Waters. Marine Pollution Bulletin. 1989;20(1):22-6.

161. Iwata H, Tanabe S, Miyazaki N, Tatsukawa R. Detection of butyltin compound residues in the blubber of marine mammals. Marine Pollution Bulletin. 1994;28(10):607-12.

162. Bryan GW, Gibbs PE, Hummerstone LG, Burt GR. The Decline of the Gastropod Nucella Lapillus Around South-West England: Evidence for the Effect of Tributyltin from Antifouling Paints. Journal of the Marine Biological Association of the United Kingdom. 1986;66(3):611-40.

163. Bryan GW, Gibbs PE, Burt GR, Hummerstone LG. The effects of tributyltin (TBT) accumulation on adult dog-whelks, Nucella lapillus: long-term field and laboratory experiments. Journal of the Marine Biological Association of the United Kingdom. 1987;67(3):525-44.

164. Evans SM, Nicholson GJ. The use of imposex to assess tributyltin contamination in coastal waters and open seas. Science of The Total Environment. 2000;258(1-2):73-80.

165. McAllister BG, Kime DE. Early life exposure to environmental levels of the aromatase inhibitor tributyltin causes masculinisation and irreversible sperm damage in zebrafish (Danio rerio). Aquatic Toxicology. 2003;65(3):309-16.

166. Sternberg RM, LeBlanc GA. Kinetic characterization of the inhibition of acyl coenzyme A:Steroid acyltransferases by tributyltin in the eastern mud snail (Ilyanassa obsoleta). Aquatic Toxicology. 2006;78(3):233-42.

167. Matthiessen P, Gibbs PE. Critical appraisal of the evidence for tributyltinmediated endocrine disruption in mollusks - Annual Review. Environmental Toxicology and Chemistry. 1998;17(1):37-43.

168. Champ MA. A review of organotin regulatory strategies, pending actions, related costs and benefits. Science of The Total Environment. 2000;258(1-2):21-71. 
169. NORMAN-23/DPC. Normas da Autoridade Marítima para o Controle de Sistemas Antiincrustantes Danosos em Embarcações. Marinha do Brasil - Diretoria de Portos e Costas. 2007.

170. CONAMA. Resolução No 357, de 17 de março de 2005, Alterada pela Resolução 410/2009 e pela 430/2011. Diário Oficial da União. 2005:58-63.

171. Gibbs PE, Pascoe PL, Bryan GW. Tributyltin-induced imposex in stenoglossan gastropods: Pathological effects on the female reproductive system. Comparative Biochemistry and Physiology Part C: Comparative Pharmacology. 1991;100(1):2315.

172. Mu Y-M, Yanase T, Nishi Y, Waseda N, Oda T, Tanaka A, et al. Insulin Sensitizer, Troglitazone, Directly Inhibits Aromatase Activity in Human Ovarian Granulosa Cells. Biochemical and Biophysical Research Communications. 2000;271(3):710-3.

173. Saitoh M, Yanase T, Morinaga H, Tanabe M, Mu Y-M, Nishi Y, et al. Tributyltin or Triphenyltin Inhibits Aromatase Activity in the Human Granulosa-like Tumor Cell Line KGN. Biochemical and Biophysical Research Communications. 2001;289(1):198-204.

174. Nishikawa J-i, Mamiya S, Kanayama T, Nishikawa T, Shiraishi F, Horiguchi T. Involvement of the Retinoid X Receptor in the Development of Imposex Caused by Organotins in Gastropods. Environmental Science \& Technology. 2004;38(23):62716.

175. Kanayama T, Kobayashi N, Mamiya S, Nakanishi T, Nishikawa J-i. Organotin Compounds Promote Adipocyte Differentiation as Agonists of the Peroxisome Proliferator-Activated Receptor $y /$ Retinoid $X$ Receptor Pathway. Molecular Pharmacology. 2005;67(3):766-74.

176. Tontonoz P, Hu E, Graves RA, Budavari AI, Spiegelman BM. mPPAR gamma 2: tissue-specific regulator of an adipocyte enhancer. Genes \& Development. 1994;8(10):1224-34.

177. Inadera $\mathrm{H}$, Shimomura A. Environmental chemical tributyltin augments adipocyte differentiation. Toxicology Letters. 2005;159(3):226-34.

178. Biemann R, Fischer B, Blüher M, Navarrete Santos A. Tributyltin affects adipogenic cell fate commitment in mesenchymal stem cells by a PPARY independent mechanism. Chemico-Biological Interactions. 2014;214:1-9. 
179. le Maire A, Grimaldi M, Roecklin D, Dagnino S, Vivat-Hannah V, Balaguer P, et al. Activation of RXR-PPAR heterodimers by organotin environmental endocrine disruptors. EMBO Reports. 2009;10(4):367-73.

180. Penza M, Jeremic M, Marrazzo E, Maggi A, Ciana P, Rando G, et al. The environmental chemical tributyltin chloride (TBT) shows both estrogenic and adipogenic activities in mice which might depend on the exposure dose. Toxicology and Applied Pharmacology. 2011;255(1):65-75.

181. Chamorro-García R, Sahu M, Abbey RJ, Laude J, Pham N, Blumberg B. Transgenerational Inheritance of Increased Fat Depot Size, Stem Cell Reprogramming, and Hepatic Steatosis Elicited by Prenatal Exposure to the Obesogen Tributyltin in Mice. Environmental Health Perspectives. 2013;121(3):35966.

182. ECHA. Information on Chemicals - https://echa.europa.eu/information-onchemicals (accessed Nov. 16, 2016). European Chemicals Agency. 2016.

183. Ohhira S, Watanabe M, Matsui $\mathrm{H}$. Metabolism of tributyltin and triphenyltin by rat, hamster and human hepatic microsomes. Archives of Toxicology. 2003;77(3):138-44.

184. PubChem Compound Database. Dibutyltin diacetate, $C I D=16682740$, https://pubchem.ncbi.nlm.nih.gov/compound/16682740 - section=Top (accessed Nov. 6, 2016). National Center for Biotechnology Information, Compound Database. 2016.

185. PubChem Compound Database. Dibutyltin dichloride, $C I D=12688$ https://pubchem.ncbi.nlm.nih.gov/compound/12688 - section=Top (accessed Nov. 6, 2016). National Center for Biotechnology Information, Compound Database. 2016.

186. PubChem Compound Database. Dibutyltin dilaurate, $\quad C I D=16682738$ https://pubchem.ncbi.nlm.nih.gov/compound/16682738 (accessed Nov. 6, 2016). National Center for Biotechnology Information, Compound Database. 2016.

187. PubChem Compound Database. Dibutyltin maleate, CID $=16684310$ https://pubchem.ncbi.nlm.nih.gov/compound/16684310 - section=Top (accessed Nov. 6, 2016). National Center for Biotechnology Information, Compound Database. 2016.

188. PubChem Compound Database. Dibutyltin oxide, $C I D=61221$ https://pubchem.ncbi.nlm.nih.gov/compound/61221 - section=Top (accessed Nov. 6, 2016). National Center for Biotechnology Information, Compound Database. 2016. 
189. Sadiki A-D, Williams DT. A study on organotin levels in Canadian drinking water distributed through PVC pipesa. Chemosphere. 1999;38(7):1541-8.

190. Azenha M, Vasconcelos MT. Butyltin Compounds in Portuguese Wines. Journal of Agricultural and Food Chemistry. 2002;50(9):2713-6.

191. Liu J-y, Jiang G-b. Survey on the Presence of Butyltin Compounds in Chinese Alcoholic Beverages, Determined by Using Headspace Solid-Phase Microextraction Coupled with Gas Chromatography-Flame Photometric Detection. Journal of Agricultural and Food Chemistry. 2002;50(23):6683-7.

192. Dudimah FD, Gibson C, Whalen MM. Effect of dibutyltin on ATP levels in human natural killer cells. Environmental toxicology. 2007;22(2):117-23.

193. Snoeij NJ, Penninks AH, Seinen W. Dibutyltin and tributyltin compounds induce thymus atrophy in rats due to a selective action on thymic lymphoblasts. International Journal of Immunopharmacology. 1988;10(7):891-9.

194. Ema M, Harazono A. Adverse effects of dibutyltin dichloride on initiation and maintenance of rat pregnancy. Reproductive Toxicology. 2000;14(5):451-6.

195. Ema M, Itami T, Kawasaki H. Susceptible period for the teratogenicity of di-nbutyltin dichloride in rats. Toxicology. 1992;73(1):81-92.

196. Tsutomu N, Shigeru M, Akemichi B. Teratogenic effects of various di-nbutyltins with different anions and butyl(3-hydroxybutyl)tin dilaurate in rats. Toxicology. 1993;85(2):149-60.

197. Hiromori Y, Nishikawa J-i, Yoshida I, Nagase H, Nakanishi T. Structuredependent activation of peroxisome proliferator-activated receptor (PPAR) $\mathrm{Y}$ by organotin compounds. Chemico-Biological Interactions. 2009;180(2):238-44.

198. Yanik SC, Baker AH, Mann KK, Schlezinger JJ. Organotins Are Potent Activators of PPARY and Adipocyte Differentiation in Bone Marrow Multipotent Mesenchymal Stromal Cells. Toxicological Sciences. 2011;122(2):476-88.

199. TIB Chemicals A. Comment: Proposal for harmonization classification for Dibutylin dilaurate. Helsinki, Finland: TIB Chemicals; 2014.

200. Mosmann T. Rapid colorimetric assay for cellular growth and survival: Application to proliferation and cytotoxicity assays. Journal of Immunological Methods. 1983;65(1):55-63.

201. Masters JR. HeLa cells 50 years on: the good, the bad and the ugly. Nat Rev Cancer. 2002;2(4):315-9. 
202. Milton FA. Avaliação do perfil de expressão gênica modulado pelo GQ-16 em adipócitos 3T3-L1 utilizando a técnica de microarranjo. Tese de Doutorado. 2015;Universidade de Brasília:143 p.

203. Gregoire FM, Smas CM, Sul HS. Understanding Adipocyte Differentiation. Physiological Reviews. 1998;78(3):783-809.

204. P Cornelius, O A MacDougald a, Lane MD. Regulation of Adipocyte Development. Annual Review of Nutrition. 1994;14(1):99-129.

205. Ntambi JM, Young-Cheul K. Adipocyte Differentiation and Gene Expression. The Journal of Nutrition. 2000;130(12):3122S-6S.

206. Green $\mathrm{H}$, Meuth M. An established pre-adipose cell line and its differentiation in culture. Cell. 1974;3(2):127-33.

207. Green $\mathrm{H}$, Kehinde O. An established preadipose cell line and its differentiation in culture II. Factors affecting the adipose conversion. Cell. 1975;5(1):19-27.

208. ZenBio. 3T3-L1 Cell Care Manual: Maintenance and Differentiation of 3T3-L1 Preadipocytes to Adipocytes. ZenBio, Inc. 2015.

209. Lee G, Elwood F, McNally J, Weiszmann J, Lindstrom M, Amaral K, et al. T0070907, a Selective Ligand for Peroxisome Proliferator-activated Receptor $Y$, Functions as an Antagonist of Biochemical and Cellular Activities. Journal of Biological Chemistry. 2002;277(22):19649-57.

210. Bradford MM. A rapid and sensitive method for the quantitation of microgram quantities of protein utilizing the principle of protein-dye binding. Analytical Biochemistry. 1976;72(1):248-54.

211. Milton FA, Cvoro A, Amato AA, Sieglaff DH, Filgueira CS, Arumanayagam AS, et al. PPARY partial agonist GQ-16 strongly represses a subset of genes in 3T3-L1 adipocytes. Biochemical and Biophysical Research Communications. 2015;464(3):718-23.

212. Rosen ED, Walkey CJ, Puigserver P, Spiegelman BM. Transcriptional regulation of adipogenesis. Genes \& Development. 2000;14(11):1293-307.

213. Yamauchi T, Kamon J, Waki H, Terauchi Y, Kubota N, Hara K, et al. The fatderived hormone adiponectin reverses insulin resistance associated with both lipoatrophy and obesity. Nat Med. 2001;7(8):941-6. 
214. Combs TP, Wagner JA, Berger J, Doebber T, Wang W-J, Zhang BB, et al. Induction of Adipocyte Complement-Related Protein of 30 Kilodaltons by PPARY Agonists: A Potential Mechanism of Insulin Sensitization. Endocrinology. 2002;143(3):998-1007.

215. Spiegelman BM, Choy L, Hotamisligil GS, Graves RA, Tontonoz P. Regulation of adipocyte gene expression in differentiation and syndromes of obesity/diabetes. $\begin{array}{llll}\text { Journal of Biological } & \text { Chemistry. 1993;268(10 \%U }\end{array}$ http://www.jbc.org/content/268/10/6823.short):6823-6.

216. Wu Z, Xie Y, Morrison RF, Bucher NL, Farmer SR. PPARgamma induces the insulin-dependent glucose transporter GLUT4 in the absence of C/EBPalpha during the conversion of $3 T 3$ fibroblasts into adipocytes. The Journal of Clinical Investigation. 1998;101(1):22-32.

217. Köninger J, Giese NA, Bartel M, di Mola FF, Berberat PO, di Sebastiano P, et al. The ECM proteoglycan decorin links desmoplasia and inflammation in chronic pancreatitis. Journal of Clinical Pathology. 2006;59(1):21-7.

218. Xaus J, Comalada M, Cardó M, Valledor AF, Celada A. Decorin inhibits macrophage colony-stimulating factor proliferation of macrophages and enhances cell survival through induction of p2 $7^{\text {Kip1 }}$ and p21 ${ }^{\text {Waf1 }}$. Blood. 2001;98(7):2124-33.

219. Ward M, Ajuwon KM. Regulation of pre-adipocyte proliferation and apoptosis by the small leucine-rich proteoglycans, biglycan and decorin. Cell Proliferation. 2011;44:343-51.

220. Daquinag Alexes $C$, Zhang $Y$, Amaya-Manzanares F, Simmons Paul J, Kolonin Mikhail G. An Isoform of Decorin Is a Resistin Receptor on the Surface of Adipose Progenitor Cells. Cell Stem Cell. 2011;9(1):74-86.

221. Stecher VF, Kaplan JE, Connolly K, Mielen S, Saelens JK. Fibronectin in acute and chronic inflammation. Arthritis and Rheumatism. 1986;29(3):394-9.

222. Andersen T, Dejgaard A, Astrup A, Gluud C. Increased Plasma Fibronectin Concentrations in Obesity: Normalization during Weight Loss. Acta Medica Scandinavica. 1987;222:275-9.

223. Osborn L, Hession C, Tizard R, Vassallo C, Luhowskyj S, Chi-Rosso G, et al. Direct expression cloning of vascular cell adhesion molecule 1 , a cytokine-induced endothelial protein that binds to lymphocytes. Cell. 1989;59(6):1203-11. 
224. Hwang S-J, Ballantyne CM, Sharrett AR, Smith LC, Davis CE, Gotto AM, et al. Circulating Adhesion Molecules VCAM-1, ICAM-1, and E-selectin in Carotid Atherosclerosis and Incident Coronary Heart Disease Cases. The Atherosclerosis Risk In Communities (ARIC) Study. 1997;96(12):4219-25.

225. Cybulsky MI, liyama K, Li H, Zhu S, Chen M, liyama M, et al. A major role for VCAM-1, but not ICAM-1, in early atherosclerosis. Journal of Clinical Investigation. 2001;107(10):1255-62.

226. Livak KJ, Schmittgen TD. Analysis of Relative Gene Expression Data Using Real-Time Quantitative PCR and the 2- $\Delta \Delta C T$ Method. Methods. 2001;25(4):402-8.

227. Bustin SA, Benes V, Garson JA, Hellemans J, Huggett J, Kubista M, et al. The MIQE Guidelines: Minimum Information for Publication of Quantitative Real-Time PCR Experiments. Clinical Chemistry. 2009;55(4):611-22.

228. Lehrke M, Lazar MA. The many faces of PPARy. Cell. 2005;123(6):993-9.

229. ATCC. RAW 264.7 Product Sheet. American Type Culture Collection - ATCC. 2016.

230. Nakamuta M, Enjoji M, Uchimura K, Ohta S, Sugimoto R, Kotoh K, et al. Bisphenol A diglycidyl ether (BADGE) suppresses tumor necrosis factor- $\alpha$ production as a PPARy agonist in the murine macrophage-like cell line, RAW 264.7. Cell biology international. 2002;26(3):235-41.

231. Zhang L, Chawla A. Role of PPAR gamma in macrophage biology and atherosclerosis. Trends in Endocrinology \& Metabolism. 2004;15(10):500-5.

232. Hughes TS, Giri PK, de Vera IMS, Marciano DP, Kuruvilla DS, Shin Y, et al. An alternate binding site for PPARy ligands. Nature Communications. 2014;5:3571.

233. Aluoch AO, Odman-Ghazi SO, Whalen MM. Alteration of an essential NK cell signaling pathway by low doses of tributyltin in human natural killer cells. Toxicology. 2006;224(3):229-37.

234. Lavastre V, Girard D. Tributyltin induces human neutrophil apoptosis and selective degradation of cytoskeletal proteins by caspases. Journal of Toxicology and Environmental Health, Part A. 2002;65(14):1013-24.

235. Edvardsson U, Bergström M, Alexandersson M, Bamberg K, Ljung B, Dahllöf B. Rosiglitazone (BRL49653), a PPARy-selective agonist, causes peroxisome proliferator-like liver effects in obese mice. Journal of Lipid Research. 1999;40(7):1177-84. 
236. Olefsky JM. Treatment of insulin resistance with peroxisome proliferatoractivated receptor y agonists. Journal of Clinical Investigation. 2000;106(4):467-72. 


\section{APÊNDICE A - INFORMAÇÕES SOBRE OS PRIMERS}

Adipoq: $\quad$ forward 5' - GCA CTG GCA AGT TCT ACT GCA A - 3'

reverse 5' - GTA GGT GAA GAG AAC GGC CTT GT - 3'
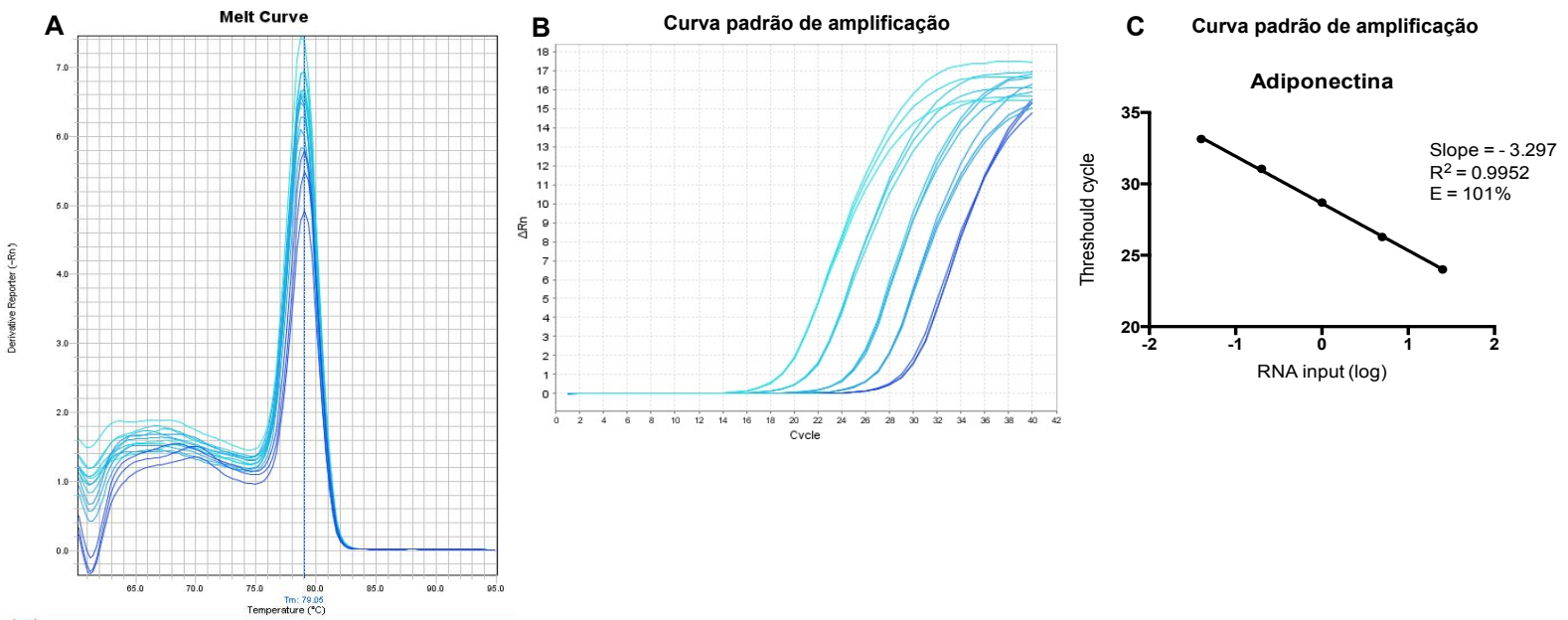

Dcn:

forward 5' - TCA CAG AAG CGG TAA CGA GC - 3'

reverse 5' - TCA TGT ATT TTC ACG ACC TTC TGA - 3'
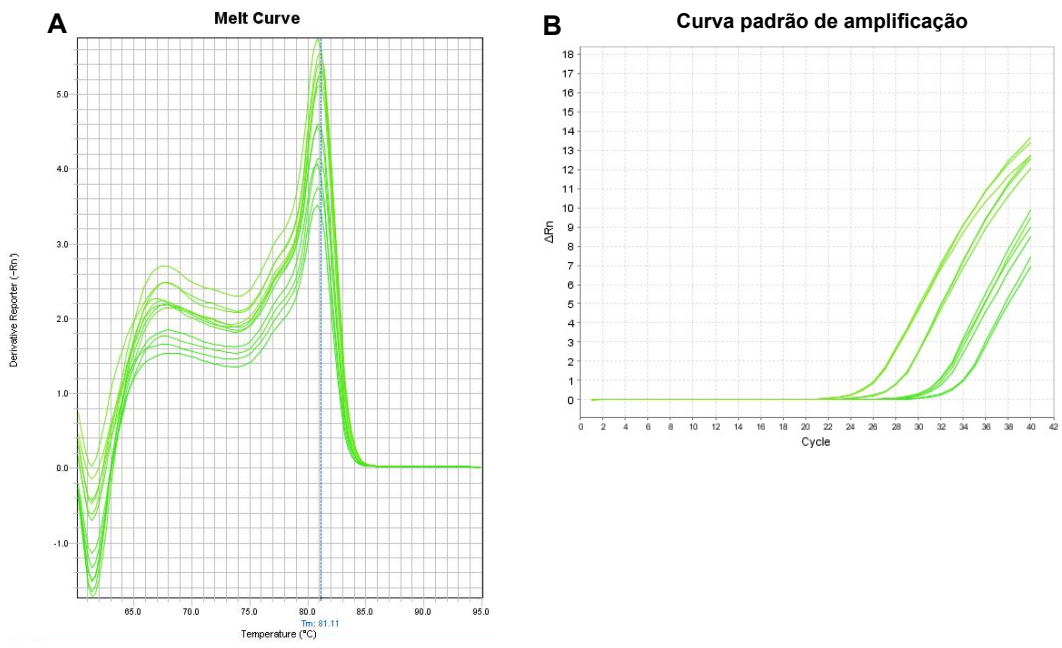

C Curva padrão de amplificação

Den

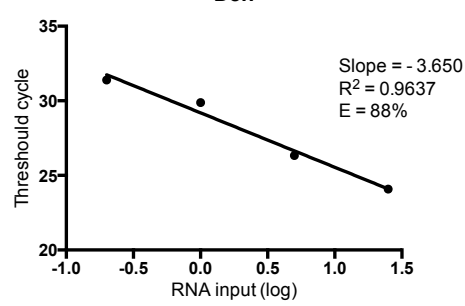

Validação dos primers. (A) Curva de Melting (Melt Curve) mostrando a especificidade de amplificação dos primers. A presença de apenas um pico na curva indica a amplificação de um produto específico. (B e C) Curvas padrões de amplificação mostrando que a eficiência de amplificação dos genes alvos e de referência (Gapdh) são semelhantes. (B) Curvas padrões foram feitas para cada par de primers, partindo-se de uma amostra de RNA de $25 \mathrm{ng}$ e diluindo-se sequencialmente para 5, 1, 0,2 e 0,04 ng. (C) As diluições foram feitas em triplicata e as médias dos valores dos $\mathrm{Ct}$ dos genes foram representadas graficamente em função do log da diluição correspondente. A eficiência de amplificação dos primers foi calculada utilizando-se a equação $\left(10^{-1 / s l o p e}-1\right) * 100$ (slope $=$ inclinação da reta da curva padrão). $E=$ Eficiência de amplificação e $R^{2}=$ coeficiente de determinação. Eficiências de amplificação do gene alvo e de referência entre $90-110 \%$ foram consideradas semelhantes. 
Fabp4: $\quad$ forward 5' - CCA TCT AGG GTT ATG CTC TTC A - 3'

reverse 5' - ACA CCG AGA TTT CCT TCA AAC TG - 3'
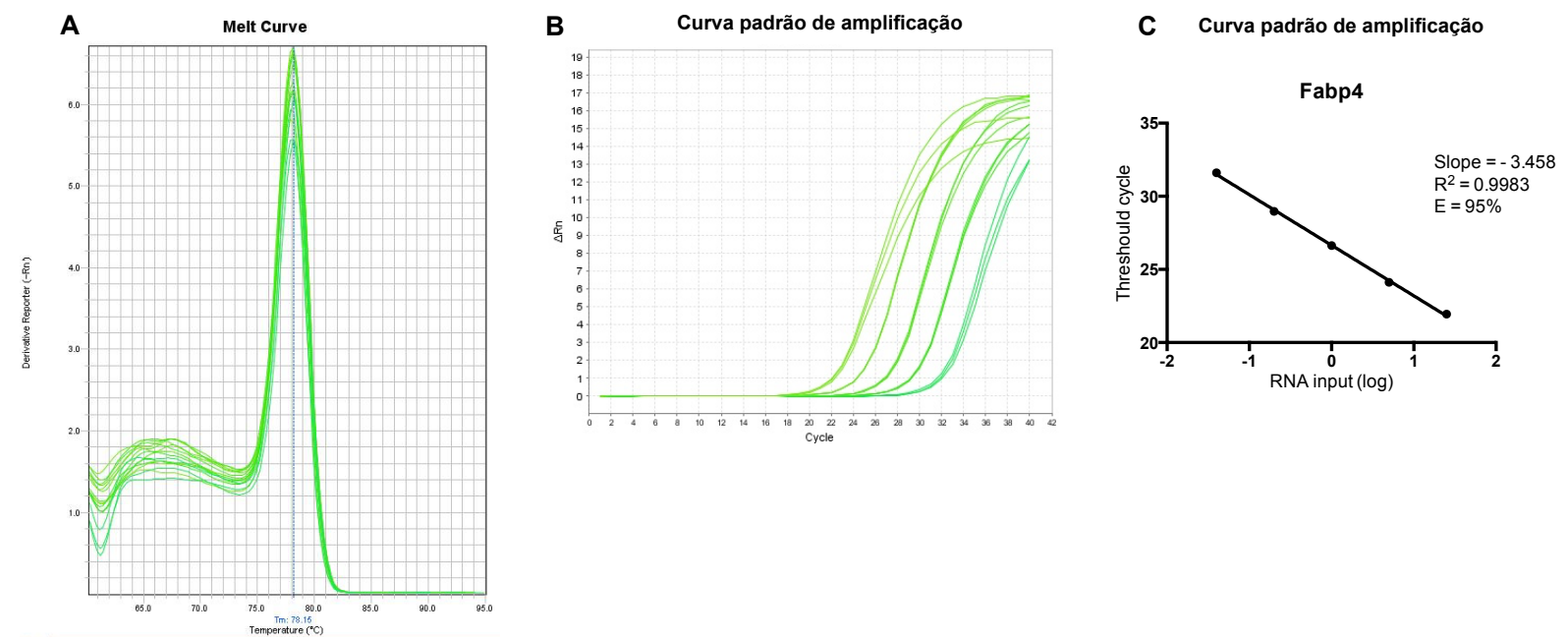

Fn1:

forward 5' - CTG CGC TCC ATT CCA CCT TA - 3'

reverse 5' - GGT CGT ACA CCC AGC TTG AA - 3'
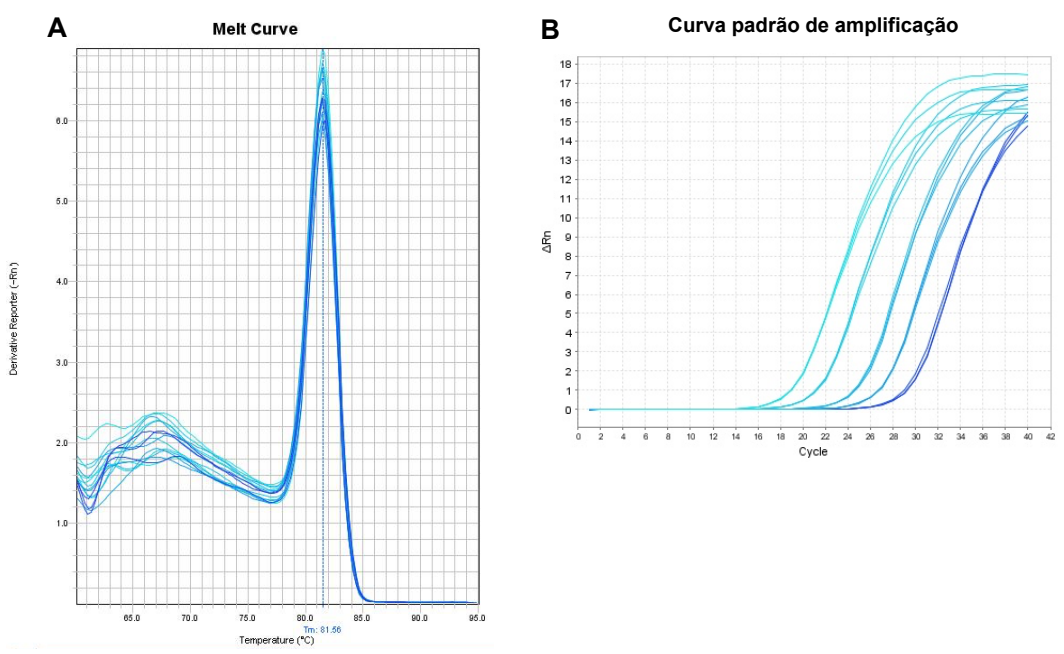

C Curva padrão de amplificação

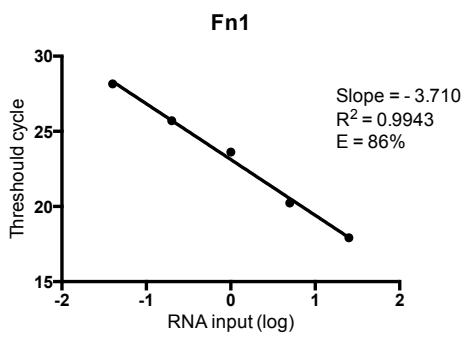

Validação dos primers. (A) Curva de Melting (Melt Curve) mostrando a especificidade de amplificação dos primers. A presença de apenas um pico na curva indica a amplificação de um produto específico. (B e C) Curvas padrões de amplificação mostrando que a eficiência de amplificação dos genes alvos e de referência (Gapdh) são semelhantes. (B) Curvas padrões foram feitas para cada par de primers, partindo-se de uma amostra de RNA de 25 ng e diluindo-se sequencialmente para 5, 1, 0,2 e 0,04 ng. (C) As diluições foram feitas em triplicata e as médias dos valores dos $\mathrm{Ct}$ dos genes foram representadas graficamente em função do log da diluição correspondente. A eficiência de amplificação dos primers foi calculada utilizando-se a equação $\left(10^{-1 / \text { slope }}-1\right) * 100$ (slope $=$ inclinação da reta da curva padrão). $\mathrm{E}=$ Eficiência de amplificação e $\mathrm{R}^{2}=$ coeficiente de determinação. Eficiências de amplificação do gene alvo e de referência entre 90-110\% foram consideradas semelhantes. 
Gapdh: $\quad$ forward 5' - AAG GGC TCA TGA CCA CAG TC - 3'

reverse 5' - CAG GGA TGA TGT TCT GGG CA - 3'

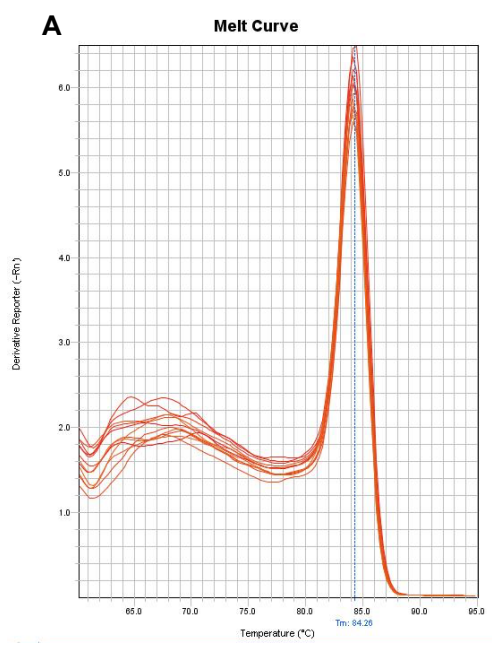

B Curva padrão de amplificação

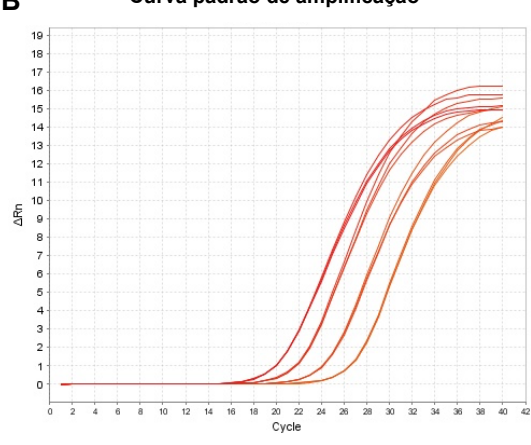

C Curva padrão de amplificação

GAPDH

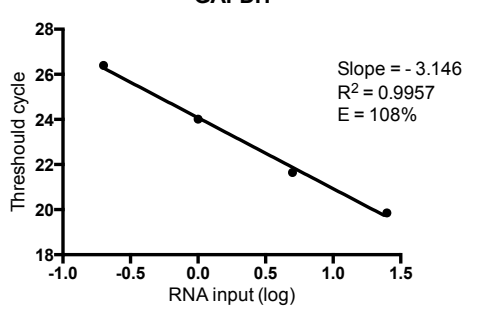

Glut4: $\quad$ forward 5' - TCA TTG TCG GCA TGG GTT T - 3' reverse 5' - CGG CAA ATA GAA GGA AGA CGT A - 3'
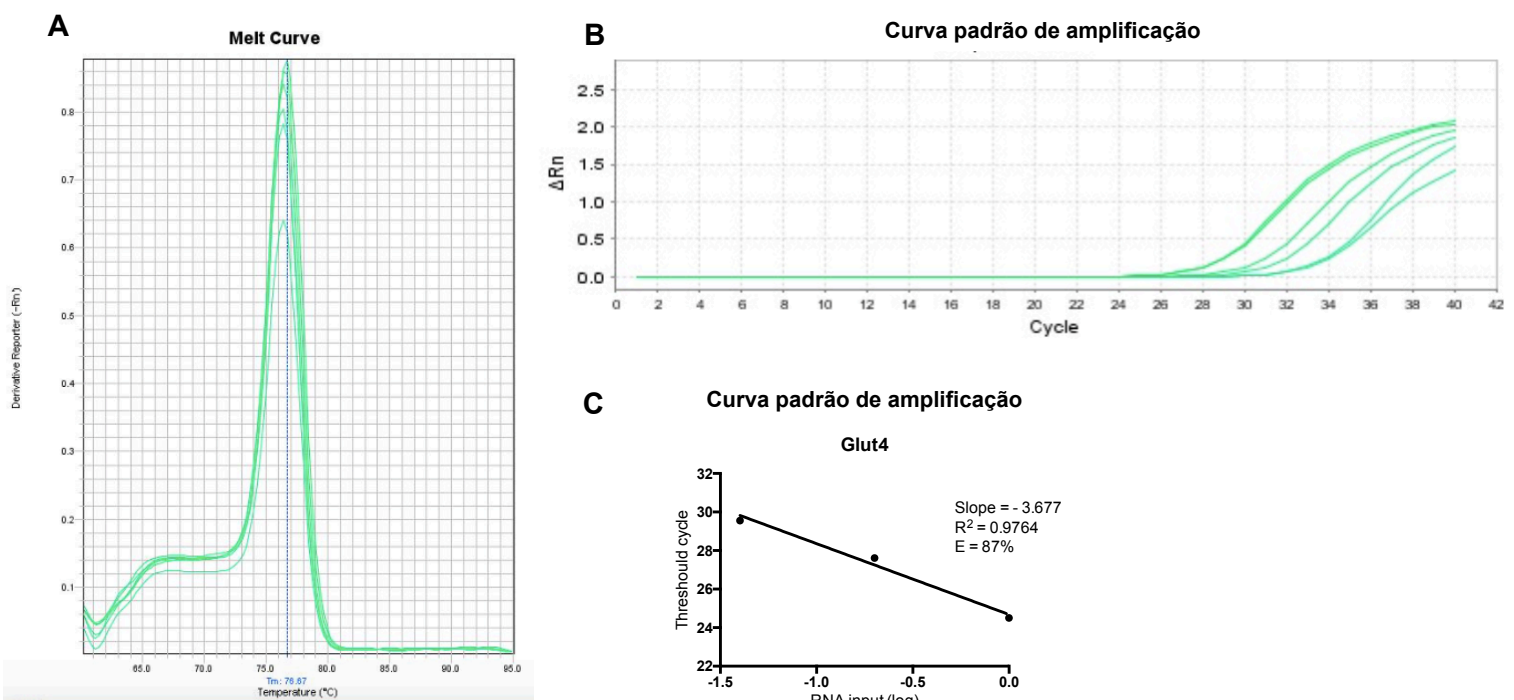

C

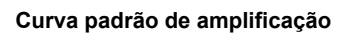

Glut4

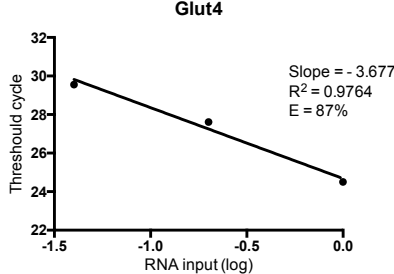

Validação dos primers. (A) Curva de Melting (Melt Curve) mostrando a especificidade de amplificação dos primers. A presença de apenas um pico na curva indica a amplificação de um produto específico. (B e C) Curvas padrões de amplificação mostrando que a eficiência de amplificação dos genes alvos e de referência (Gapdh) são semelhantes. (B) Curvas padrões foram feitas para cada par de primers, partindo-se de uma amostra de RNA de $25 \mathrm{ng}$ (Gapdh) ou $5 \mathrm{ng}$ (Glut 4) e diluindo-se sequencialmente (fator de diluição = 5). (C) As diluições foram feitas em triplicata e as médias dos valores dos $\mathrm{Ct}$ dos genes foram representadas graficamente em função do log da diluição correspondente. A eficiência de amplificação dos primers foi calculada utilizando-se a equação $\left(10^{-1 / s l o p e}-1\right){ }^{*} 100$ (slope = inclinação da reta da curva padrão). $E=$ Eficiência de amplificação e $R^{2}=$ coeficiente de determinação. Eficiências de amplificação do gene alvo e de referência entre $90-110 \%$ foram consideradas semelhantes. 
TNFa: $\quad$ forward 5' - CCC TCA CAC TCA GAT CAT CTT CT - 3'

reverse 5' - GCT ACG ACG TGG GCT ACA G - 3'
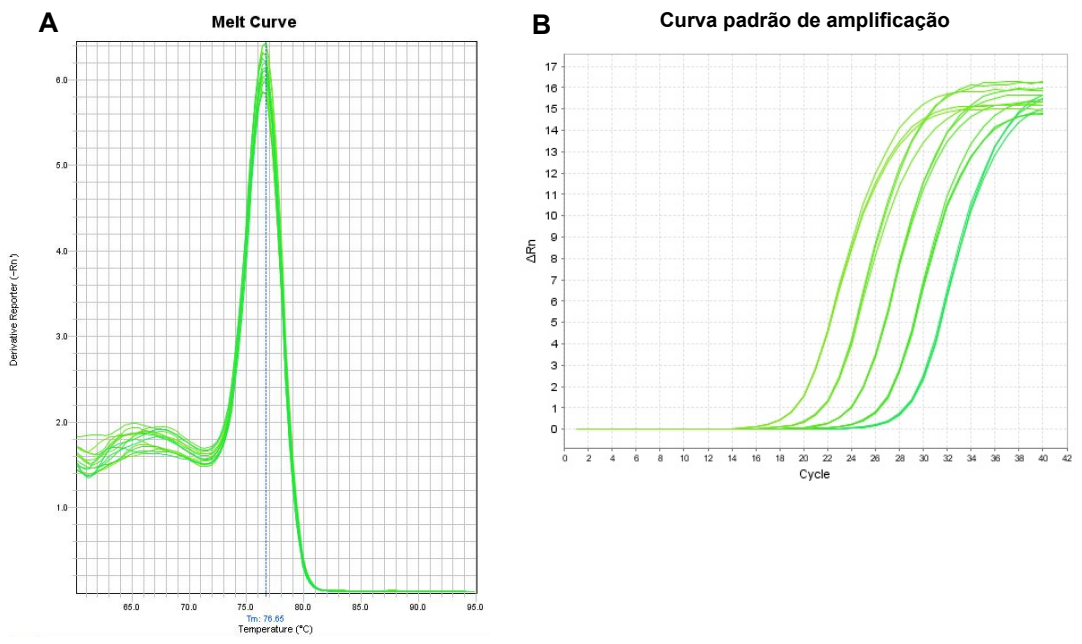

C Curva padrão de amplificação

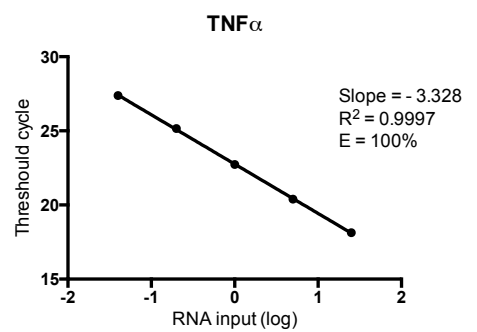

Vcam1: $\quad$ forward 5' - TGG AGG TCT ACT CAT TCC CTG A - 3' reverse 5' - GAC AGG TCT CCC ATG CAC AA - 3'

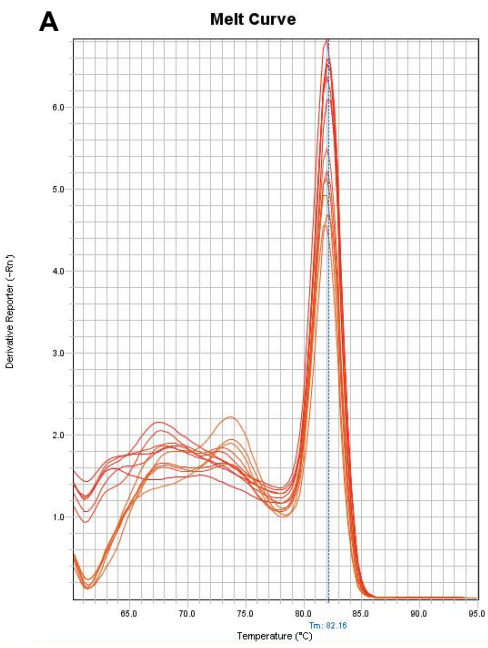

B

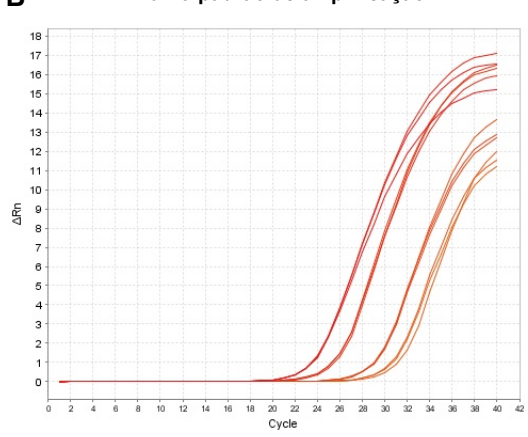

C Curva padrão de amplificação

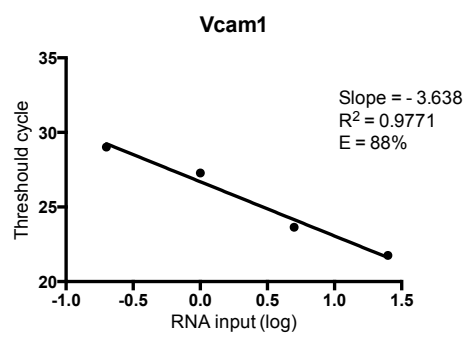

Validação dos primers. (A) Curva de Melting (Melt Curve) mostrando a especificidade de amplificação dos primers. A presença de apenas um pico na curva indica a amplificação de um produto específico. (B e C) Curvas padrões de amplificação mostrando que a eficiência de amplificação dos genes alvos e de referência (Gapdh) são semelhantes. (B) Curvas padrões foram feitas para cada par de primers, partindo-se de uma amostra de RNA de $25 \mathrm{ng}$ e diluindo-se sequencialmente para 5, 1, 0,2 e 0,04 ng. (C) As diluições foram feitas em triplicata e as médias dos valores dos $\mathrm{Ct}$ dos genes foram representadas graficamente em função do log da diluição correspondente. A eficiência de amplificação dos primers foi calculada utilizando-se a equação $\left(10^{-1 / s l o p e}-1\right){ }^{*} 100\left(\right.$ slope $=$ inclinação da reta da curva padrão). $E=$ Eficiência de amplificação e $R^{2}=$ coeficiente de determinação. Eficiências de amplificação do gene alvo e de referência entre $90-110 \%$ foram consideradas semelhantes. 


\section{APÊNDICE B - EFEITO DO GQ-16 SOBRE A EXPRESSÃO DE GENES NO CORAÇÃO DE CAMUNDONGOS COM OBESIDADE E RESISTÊNCIA À INSULINA INDUZIDAS POR DIETA}

\section{INTRODUÇÃO}

O diabetes mellitus (DM) é uma das maiores causas de mortalidade e morbidade mundial. Atualmente, estima-se que cerca de 415 milhões de pessoas em todo o mundo sejam portadoras de DM, sendo que $90 \%$ desta população diabética está acometida pelo diabetes mellitus tipo 2 (DM2) (1-3).

Segundo a Sociedade Americana de Diabetes, o DM2 é uma doença metabólica caracterizada por uma deficiência (geralmente relativa) na ação da insulina, o que acaba causando a hiperglicemia. Entretanto, esta doença não está associada apenas a um desequilíbrio na homeostase da glicose. O DM2 também pode causar sérias complicações nos olhos e nos tecidos cardiovascular, nervoso, renal e esquelético $(3,4)$.

O tratamento do DM2 inclui modificações nos hábitos de vida dos pacientes, o uso de fármacos e, em alguns casos, a administração de insulina. Os agentes antihiperglicemiantes pertencentes à classe das tiazolidinadionas (TZDs) tais como a rosiglitazona, a pioglitazona e a troglitazona são exemplos de fármacos que foram amplamente utilizadas no controle do DM2 (5). Entretanto, o uso destes foi suspenso em diversos países, incluindo o Brasil, em decorrência dos graves efeitos adversos causados por eles, como o aumento do risco de infarto do miocárdio e de mortes por causas cardiovasculares (6). O uso de TZDs também está associado a uma maior fragilidade óssea (7) e ganho de massa corporal (5).

As TZDs são agonistas totais dos receptores ativados por proliferadores peroxissomais do tipo y (PPARY) (8) e estes fármacos acabam superativando este receptor e potencializando tanto os efeitos benéficos quanto os maléficos decorrentes da ativação desta isoforma $(5,9)$. Devido a isso, é crescente o interesse de se estudar os efeitos de ligantes parciais com o intuito de ativar o PPARy sem causar tantos efeitos adversos (9-13). 
Nesta tendência, pesquisadores do Laboratório de Farmacologia Molecular da Universidade de Brasília em parceria com outros colaboradores mostraram o efeito de um novo ligante sintético do PPARy, o GQ-16. Este composto, um agonista parcial do PPARy, aumentou a sensibilidade à insulina, porém, sem promover o ganho de peso (10).

A diminuição da resistência à insulina juntamente com uma menor atividade adipogênica causadas por este composto são resultados bastante promissores que levantam a questão se outros efeitos adversos decorrentes do uso de TZDs também são minimizados pelo GQ-16, como por exemplo, os causados no coração.

Baseado nestes achados, o objetivo deste estudo foi investigar o mecanismo de ação do GQ-16 sobre a expressão de genes no coração de camundongos com obesidade e resistência à insulina induzidas por dieta. 


\section{REVISÃO BIBLIOGRÁFICA}

\subsection{DIABETES MELLITUS, TIAZOLIDINADIONAS E MORTALIDADE CARDÍACA}

Dentre os efeitos adversos que contribuíram para que as TZDs fossem retiradas do mercado, no Brasil e na Europa $(14,15)$, está o fato do uso destes fármacos estar associado a um maior índice de mortalidade cardíaca nos pacientes DM2 $(5,9)$.

Uma meta-análise que avaliou 42 estudos mostrou que os pacientes diabéticos que fazem uso de rosiglitazona, tiveram um aumento no risco de infarto do miocárdio e também de morte por causas cardiovasculares (6).

Também há um trabalho que comparou o efeito das TZDs e de outros fármacos anti-hiperglicemiantes (como por exemplo, insulina, metformina e sulfoniluréia) no índice de mortalidade cardíaca em pacientes diabéticos. $\mathrm{Na}$ população estudada, o tratamento com TZDs, mais especificamente com a rosiglitazona, estava associado a um maior risco de desenvolvimento de insuficiência cardíaca, infarto agudo do miocárdio e mortalidade em comparação ao uso de outros agentes anti-hiperglicemiantes (16).

Outro estudo, observacional e retrospectivo, verificou os efeitos da rosiglitazona e da pioglitazona no risco de morte por causas cardiovasculares de pacientes diabéticos. Os resultados mostraram que em comparação com a pioglitazona, a prescrição da rosiglitazona estava associada a um maior risco de infarto agudo do miocárdio, insuficiência cardíaca e todas as outras causas de mortalidade de indivíduos diabéticos com idade superior a 65 anos (17).

A principal causa do aumento da mortalidade cardíaca em pacientes DM2 que fazem o uso de TZD é o fato destes fármacos aumentarem a retenção de fluidos (9). Isso de fato acontece e, em 2005, Zhang e colaboradores demonstraram que o aumento da retenção hídrica realmente ocorre via PPARY. Neste estudo, em comparação ao tratamento com veículo, a rosiglitazona não aumentou o volume plasmático de camundongos transgênicos com knockout de PPARy nos túbulos coletores renais. Entretanto, esse resultado não foi observado nos animais do grupo 
controle tratados com este mesmo composto, que apresentaram um maior volume plasmático (18).

Apesar de estudos indicarem que o uso das TZDs aumenta o risco de mortalidade por eventos cardiovasculares principalmente devido à maior retenção hídrica, alguns resultados indicam que outros aspectos também podem contribuir para os efeitos negativos destes fármacos no coração.

Um estudo bastante interessante realizado em 2009 mostrou que pacientes DM2 tratados com TZDs possuem maior expressão de PPARy no miocárdio em comparação aos diabéticos que não fazem uso de tais fármacos. Esta informação é extremamente importante, já que os níveis de expressão de PPARY são baixos no coração, sendo o PPARa a isoforma mais expressa nesse tecido (19). Nesse estudo, foram avaliadas amostras do miocárdio de pacientes diabéticos submetidos à cirurgia de troca de válvula devido à estenose mitral. Também foi detectada a infiltração de lipídeos em $85 \%$ das amostras de tecido cardíaco de pacientes tratados com TZDs e em apenas $10 \%$ dos tecidos de indivíduos não tratados com estes fármacos. Estes resultados indicam que a ativação do PPARY em cardiomiócitos pode ter induzido a adipogênese e/ou o acúmulo de lipídeos no miocárdio (20).

Os trabalhos com animais também vêm ajudando a compreender o papel do PPARy nas células musculares cardíacas. Camundongos transgênicos com knockout de PPARy nos cardiomiócitos tiveram hipertrofia cardíaca, mas sem alterações na função sistólica. O tratamento com rosiglitazona também provocou hipertrofia cardíaca tanto nos animais do grupo controle quanto nos transgênicos (porém, em um grau menor), demonstrando que este mecanismo pode ser parcialmente independente da ativação do PPARy expresso em cardiomiócitos (21).

Já em um modelo oposto, camundongos transgênicos que superexpressavam PPARY em cardiomiócitos apresentaram cardiomiopatia dilatada e também maior acúmulo de lipídeos (triglicerídeos e ácidos graxos livres) no tecido cardíaco em comparação aos camundongos selvagens (22).

Além disso, experimentos realizados no Laboratório de Farmacologia Molecular da Universidade de Brasília indicam que células mesenquimais derivadas do tecido cardíaco possuem potencial de se diferenciarem em adipócitos. Neste ensaio, fibroblastos isolados do coração de macacos (gênero Callithrix) e cultivados 
em meio indutor para adipogênese foram capazes de se diferenciarem em adipócitos (23).

Há também informações provenientes do Centro de Diabetes da Universidade da Califórnia (Diabetes Center, University of California, San Francisco, EUA) de que pacientes DM2, submetidos a transplante cardíaco e que faziam uso de TZDs apresentavam um aumento da adipogênese e/ou acúmulo de lipídeos no coração (24).

Diante de tudo o que foi exposto, o desenvolvimento de moduladores seletivos de PPARy, como por exemplo, de agonistas parciais desta isoforma de PPAR, capazes de regular a glicemia e causar o mínimo de efeitos adversos, parece ser o caminho a ser seguido no desenvolvimento de novas drogas antihiperglicemiantes.

\subsection{GQ-16, NOVO LIGANTE DE PPARY}

Em 2012, um grupo de pesquisadores do Laboratório de Farmacologia Molecular da Universidade de Brasília em parceria com outros colaboradores, demonstrou que um novo composto, o GQ-16 (5-(5-bromo-2-methoxybenzylidene)3-(4-methyl-benzyl)-thiazolidine-2,4-dione), um ligante específico da isoforma do tipo Y do PPAR, diminuiu a resistência à insulina, porém sem provocar o ganho de peso. $O$ aumento da massa corporal é um dos efeitos observados em decorrência da ativação do PPARy pelas TZDs e, neste estudo, este efeito não foi observado. A seguir são apresentados a estrutura química deste composto em comparação a outras TZDs (10). 

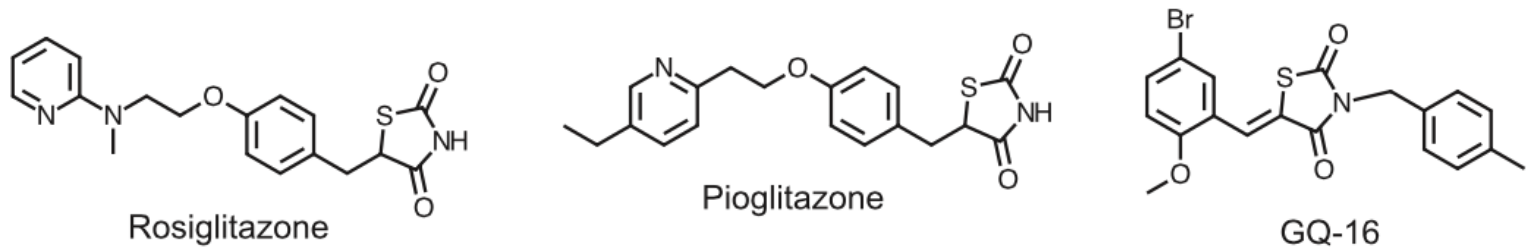

GQ-16

Figura 1. Estrutura química do GQ-16 comparado com as TZDs rosiglitazona e pioglitazona. (Figura adaptada de: Amato AA, Rajagopalan S, Lin JZ, Carvalho BM, Figueira ACM, Lu J, et al. GQ16, a Novel Peroxisome Proliferator-activated Receptor y (PPARY) Ligand, Promotes Insulin Sensitization without Weight Gain. Journal of Biological Chemistry. 2012;287(33):28169-79 (10)).

Ensaios de transfecção e gene repórter demonstraram que este composto, mesmo em doses elevadas, atinge cerca de um terço da ativação máxima alcançada com rosiglitazona, o que o caracteriza como um ligante parcial fraco do PPARy. Experimentos in vitro também indicaram que o GQ-16 promove uma interação menor entre o PPARy e seu co-ativador SRC-1 (co-ativador 1 do receptor de esteróide), quando comparado com a troglitazona (10).

Neste mesmo estudo, em células NIH-3T3-L1 (pré-adipócitos) e C3H10T1/2 (células embrionárias de camundongos não comprometidas com a diferenciação adipocitária), modelos nos quais já está bem estabelecido que a diferenciação de adipócitos é dependente da ativação de PPARy, o GQ-16 reduziu a adipogênese em comparação às amostras tratadas com rosiglitazona. E estes resultados foram confirmados nos modelos in vivo: camundongos com obesidade induzida por dieta hiperlipídica tratados tanto com rosiglitazona quanto com GQ-16 tiveram aumento da sensibilidade à insulina. Entretanto, o ganho de peso verificado pelos animais tratados com TZD não foi observado naqueles que receberam GQ-16. Além disso, nestes mesmos animais, o GQ-16 não aumentou a retenção hídrica, como ocorreu quando foi administrada rosiglitazona (10).

Com o intuito de tentar compreender o mecanismo de ação do GQ-16, estudos de dinâmica molecular foram realizados e os resultados demonstraram que o modo como este novo composto se liga ao receptor se difere da maneira como as TZDs o fazem. As TZDs, agonistas totais do PPARy, interagem diretamente com a hélice 12, localizada no LBD do receptor. A ligação das TZDs provoca uma ampla mudança conformacional e esta alteração cria, na superfície do receptor, uma região hidrofóbica que possui alta afinidade a proteínas co-ativadoras, aumentando então a 
atividade transcricional $(25,26)$. Já o GQ-16 não interage diretamente com a hélice 12, a ligação deste composto a esta parte do receptor é mediada por uma molécula de água, o que estabiliza de forma mais fraca a hélice 12, provocando então uma menor alteração conformacional e consequentemente uma resposta menos pronunciada (10). Este modo de interação do GQ-16 com o PPARY é semelhante ao de outros agonistas parciais tais como PA-082 (13), MRL-24, nTZDpa e BVT.13 (12) o que também o caracteriza como um agonista parcial fraco desta isoforma do receptor.

Entretanto, a melhora da resistência à insulina promovida pelo GQ-16 não ocorre somente devido à alteração conformacional que este composto causa na hélice 12 do receptor, que é o modo clássico de ação dos agonistas de PPARY. Em 2010, Choi e colaboradores propuseram um novo mecanismo para explicar como os agonistas desta isoforma do receptor aumentam a sensibilidade à insulina. Estes autores relataram que as TZDs e outros agonistas parciais agem inibindo a fosforilação da serina 273 (Ser-273) do PPARy pela ciclina dependente de quinase 5 (Cdk5). A fosforilação deste aminoácido desregula uma série de genes alvos da isoforma $\mathrm{y}$ do PPAR, como por exemplo, a adiponectina, que tem sua expressão diminuída (11). Conforme demonstrado no estudo de Amato e Rajagopalan (2012), o GQ-16 age estabilizando a hélice 3 e a região de folha $\beta$ do receptor, inibindo, desta forma, a fosforilação da Ser-273, conforme proposto por Choi e colaboradores (2010).

O aumento da sensibilidade à insulina aliado à fraca atividade adipogênica deste composto são resultados bastante animadores e que levantam a questão se outros efeitos adversos causados pelas TZDs também são minimizados pelo GQ-16.

O aumento do índice de mortes por causas cardiovasculares devido ao uso das TZDs pode estar relacionado, juntamente com a retenção hídrica, ao fato destes fármacos induzirem o acúmulo de lipídeos no coração. Por ser um agonista parcial, os efeitos do GQ-16 no coração podem ser menores em comparação aos das TZDs.

Baseados em todos esses achados, o nosso intuito é buscar uma compreensão mais detalhada do mecanismo de ação do GQ-16 no coração de camundongos com obesidade e resistência à insulina induzidas por dieta. 


\section{OBJETIVOS}

\subsection{OBJETIVOS GERAIS}

Verificar o efeito do GQ-16 sobre a expressão de genes relacionados à adipogênese e à inflamação no coração de camundongos com obesidade e resistência à insulina induzidas por dieta.

\subsection{OBJETIVOS ESPECÍFICOS}

- Verificar o efeito de diferentes doses de GQ-16 na massa cardíaca de camundongos com obesidade e resistência à insulina induzidas por dieta.

- Investigar o efeito do GQ-16 na expressão de genes relacionados à adipogênese e à inflamação no coração de camundongos com obesidade e resistência à insulina induzidas por dieta.

- Verificar o efeito de diferentes doses de GQ-16 na diferenciação de fibroblastos isolados do coração de camundongos em adipócitos.

- Investigar o efeito do GQ-16 na expressão de marcadores protéicos relacionados à adipogênese em fibroblastos isolados do coração de camundongos diferenciados em adipócitos.

- Investigar o efeito do GQ-16 na expressão de genes relacionados à adipogênese em fibroblastos isolados do coração de camundongos diferenciados em adipócitos. 


\section{MÉTODOS}

\subsection{GQ-16 E ROSIGLITAZONA}

O GQ-16 foi gentilmente cedido pelo Prof. Ivan da Rocha Pitta do Departamento de Antibióticos da Universidade Federal de Pernambuco e foi sintetizado conforme descrição prévia na literatura (27).

A rosiglitazona foi adquirida da Cayman Chemical.

Os experimentos foram realizados no Laboratório de Farmacologia Molecular da Universidade de Brasília.

\subsection{CUIDADOS ÉTICOS}

Este estudo foi aprovado pela Comissão de Ética no Uso Animal (CEUA) da UnB (UnB Doc 27455/2011) e todos os procedimentos adotados estão de acordo com os princípios éticos de experimentação animal (o documento encontra-se no Anexo A).

Os animais participantes deste estudo foram adquiridos do Biotério Central do Centro de Desenvolvimento de Modelos Experimentais para Medicina e Biologia da Universidade Federal de São Paulo (CEDEME - UNIFESP) que forneceu um laudo técnico atestando a qualidade sanitária dos animais (análise bacteriológica, bioquímica, hematológica e parasitológica) e uma análise de controle genético (teste de genotipagem).

As matrizes para produção dos animais foram fornecidas para o CEDEME pelo Rat Resource and Research Center, Columbia, MO - EUA. O transporte destes animais até o biotério da UnB foi de responsabilidade do fornecedor (equipe do CEDEME da UNIFESP) que seguiu todas as normas para esse tipo de transporte. 


\subsection{AMOSTRA E DELINEAMENTO EXPERIMENTAL}

A amostra foi composta por 22 camundongos Swiss machos com 3 semanas de idade. Estes animais receberam do desmame ( $3^{a}$ semana de idade) até a idade adulta (18 ${ }^{a}$ semana) dieta normolipídica (NFD - normal fat diet, grupo controle, 10\% do total de calorias proveniente de lipídeos) ou dieta hiperlipídica (HFD - high fat diet, $60 \%$ do total de calorias proveniente de lipídeos - Harlan Teklad - EUA), esta última com o intuito de induzir a obesidade e a resistência à insulina.

Os animais foram mantidos em gaiolas de plástico em um ambiente com temperatura média de $24^{\circ} \mathrm{C}$ e em ciclo claro-escuro de $12 / 12$ horas. A ingestão de água e o consumo de dieta (na forma de pellets) foram ad libitum.

$\mathrm{Na} 16^{\mathrm{a}}$ semana de idade, os animais foram subdivididos aleatoriamente em seis grupos e receberam veículo (Tween-20 a 0,25\% (v/v) diluído em solução fisiológica a $0,9 \%$ ), rosiglitazona (4 mg/kg/dia, agonista total do PPARY - controle positivo) ou GQ-16 (5, 10 ou 20 mg/kg/dia, agonista parcial e específico do PPARY). O tratamento foi feito por gavagem durante a $17^{\mathrm{a}}$ e a $18^{\mathrm{a}}$ semana, conforme descrito a seguir:

- Grupo Controle: animais alimentados com NFD e tratados com veículo $(n=4)$

- Grupo HFD: animais alimentados com HFD e tratados com veículo $(n=4)$

- Grupo HFD + ROSI: animais alimentados com HFD e tratados com rosiglitazona na dose de $4 \mathrm{mg} / \mathrm{kg} / \mathrm{dia}(\mathrm{n}=4)$

- Grupo HFD + GQ-16 (5 mg): animais alimentados com HFD e tratados com GQ-16 na dose de $5 \mathrm{mg} / \mathrm{kg} / \mathrm{dia}(\mathrm{n}=3)$

- Grupo HFD + GQ-16 (10 mg): animais alimentados com HFD e tratados com GQ16 na dose de $10 \mathrm{mg} / \mathrm{kg} / \mathrm{dia}(\mathrm{n}=3)$

- Grupo HFD + GQ-16 (20 mg): animais alimentados com HFD e tratados com GQ16 na dose de $20 \mathrm{mg} / \mathrm{kg} / \mathrm{dia}(\mathrm{n}=4)$ 


\subsection{PESO CORPORAL E GLICEMIA EM JEJUM}

Todos os animais foram pesados semanalmente da $3^{\mathrm{a}}$ a $16^{\mathrm{a}}$ semana de vida. Para a determinação da glicemia em jejum, foi feita a coleta de uma gota de sangue por punção da veia caudal e utilizado um glicosímetro (Advantage Boehringer Mannheim, EUA). A glicemia foi mensurada uma vez por semana da $12^{\mathrm{a}}$ a $16^{\mathrm{a}}$ semana de idade. Estas duas variáveis foram avaliadas com o objetivo de caracterizar o modelo experimental, ou seja, para mostrar que a dieta hiperlipídica induziu a obesidade e a resistência à insulina nos animais.

\subsection{MASSA CARDÍACA}

Com o intuito de investigar o efeito de diferentes doses de GQ-16 na massa cardíaca, os animais foram eutanasiados na $18^{\mathrm{a}}$ semana, seguindo as diretrizes sugeridas pela American Veterinary Medical Association (28). Os camundongos foram anestesiados com o anestésico inalatório isoflurano (Forane, Abbott) e, rapidamente eutanasiados por decapitação utilizando guilhotina comercial específica para camundongos adultos (Kent Scientific Coporation).

Em seguida, os corações foram extraídos, pesados em balança analítica e armazenados a $-80^{\circ} \mathrm{C}$ para posterior extração do RNA total e avaliação da expressão gênica.

\subsection{EXPRESSÃO GÊNICA NO CORAÇÃO POR RT-PCR}

Para verificar o efeito do GQ-16 na expressão de genes relacionados à adipogênese e à inflamação no coração de camundongos, inicialmente, o RNA total foi extraído do tecido cardíaco utilizando-se o reagente TRIzol ${ }^{\circledR}$ (Invitrogen - EUA) conforme as instruções do fabricante. 
Logo após, foi feita a identificação e a quantificação da expressão do gene marcador de adipogênese Fabp4 (fatty acid binding protein 4) nas amostras por meio da síntese de DNA complementar (CDNA) por transcrição reversa (RT) seguida pela amplificação por reação em cadeia da polimerase em tempo real e quantitativa (RT-PCRq).

Foi utilizado o kit Power SYBR Green-to-Ct ONE STEP (Applied Biosystems EUA) que realiza, em uma única etapa, a síntese do cDNA por RT e a amplificação por PCR quantitativa e em tempo real.

\subsection{ANÁLISE ESTATÍSTICA}

Para comparar o peso corporal e o perfil glicêmico entre os grupos que receberam dieta normolipídica e hiperlipídica, foi utilizado o teste t de Student. Já para comparar as variáveis massa cardíaca total, massa cardíaca em relação ao peso corporal e expressão gênica entre os diferentes grupos experimentais, foi usada a análise de variância de um fator (ANOVA one-way), seguida do pós-teste Newman-Keuls. Os dados estão expressos como média e erro-padrão da média e o nível de significância adotado foi de $p<0,05$. Toda a análise estatística foi realizada no programa GraphPad Prism (GraphPad Prism Software, EUA).

\section{Etapas ainda não realizadas:}

\subsection{DIFERENCIAÇÃO CELULAR: FIBROBLASTOS EM ADIPÓCITOS}

Inicialmente, os fibroblastos serão isolados do coração de camundongos, seguindo protocolo disponível na literatura (29). Em seguida, com o objetivo de verificar o efeito de diferentes doses de GQ-16 na diferenciação de fibroblastos em adipócitos, as células serão cultivadas com DMEM (Dulbecco's Modified Eagle Medium) contendo soro de bezerro e mantidas em incubadoras a $37^{\circ} \mathrm{C}$ com $5 \%$ de $\mathrm{CO}_{2}$ até atingirem $100 \%$ de confluência. 
Após a confluência, as células serão mantidas sob as mesmas condições por adicionais 48 horas para que ocorra a parada do crescimento, necessária ao processo de diferenciação.

Depois desse período, a diferenciação será induzida pela substituição do meio contendo soro de bezerro por meio DMEM contendo soro fetal bovino, $1 \mu \mathrm{g} / \mathrm{mL}$ de insulina, 0,5 nM de isometilbutilxantina e $1 \mu \mathrm{M}$ de dexametasona (todos os reagentes da Sigma-Aldrich ${ }^{\circledR}$ ), no qual as células serão mantidas por 3 dias (dia 0 ao dia 3). Ao final desse período, o meio indutor da diferenciação será substituído por meio de cultura DMEM com 10\% de soro fetal bovino, $1 \mu \mathrm{g} / \mathrm{mL}$ de insulina e $1 \mu \mathrm{M}$ de dexametasona, no qual as células serão mantidas até o momento da coleta.

As células serão tratadas com o veículo DMSO (controle negativo), rosiglitazona (controle positivo: 1, 10 e $100 \mu \mathrm{M})$ ou GQ-16 $(0,1,1$ e $10 \mu \mathrm{M})$ em dois momentos: do dia 0 ao dia 3 (com o intuito de avaliar o efeito dos ligantes no processo de diferenciação, as células serão então coletadas após esse período) e do dia 7 ao dia 8 (para investigar o efeito dos ligantes nos adipócitos maduros).

Para confirmação da adipogênese serão utilizados três métodos:

- Coloração com o reagente óleo vermelho O;

- Western Blotting utilizando anticorpos específicos para detectar marcadores de adipogênese;

- Extração de RNA seguida por Quantitative Real-time PCR (qPCR) para identificar e quantificar os transcritos dos marcadores de diferenciação de adipócitos. Todas as técnicas estão descritas a seguir.

\subsubsection{Coloração com óleo vermelho 0}

Após a diferenciação, as células serão fixadas com formaldeído $4 \%$, lavadas com PBS e coradas com óleo vermelho O (Sigma-Aldrich ${ }^{\circledR}$ ) a 0,3\%. Este reagente pigmenta as gotículas de lipídeos, o que permite verificar se ocorreu a adipogênese (30). 


\subsubsection{Western Blotting}

Também será verificado o efeito do GQ-16 na expressão de marcadores protéicos relacionados à adipogênese nos fibroblastos isolados do coração de camundongos diferenciados em adipócitos.

Após o período de diferenciação, as células serão lisadas utilizando-se uma solução contendo $50 \mathrm{mM}$ Tris $(\mathrm{pH} 7,5), 150 \mathrm{mM} \mathrm{NaCl}, 1 \%$ Triton X-100 e inibidor de protease. O lisado será analisado por eletroforese em gel de poliacrilamida (SDSPAGE) e transferido para uma membrana de PVDF (Invitrogen ${ }^{\circledR}$ ). A membrana será bloqueada com caseína a $5 \%$ e então incubada com os anticorpos primários específicos para detectar os marcadores de adipogênese (anti-FABP4, anti-PPARY e anti-adiponectina, todos da abcam $^{\circledR}$ ) e, em seguida, com os anticorpos secundários. Após a lavagem da membrana, as proteínas marcadas com os anticorpos serão visualizadas por autorradiografia e quimioluminescência usando-se o kit Amersham ECL Prime Western Blotting Detection Reagent ${ }^{\circledR}$.

\subsubsection{Expressão gênica nos adipócitos}

Após a diferenciação dos fibroblastos (isolados do coração dos camundongos) em adipócitos, será analisado o efeito do GQ-16 na expressão de genes relacionados à adipogênese nas células diferenciadas.

A expressão de Fabp4, PPARy e Adipoq será feita por meio da RT-PCRq seguindo todos os procedimentos descritos no item "Expressão gênica no coração". 


\section{RESULTADOS PARCIAIS}

\subsection{PESO CORPORAL E GLICEMIA EM JEJUM}

O peso corporal dos animais que receberam dieta hiperlipídica foi maior na $16^{\mathrm{a}}$ semana quando comparado ao grupo controle (Figura 1).

A

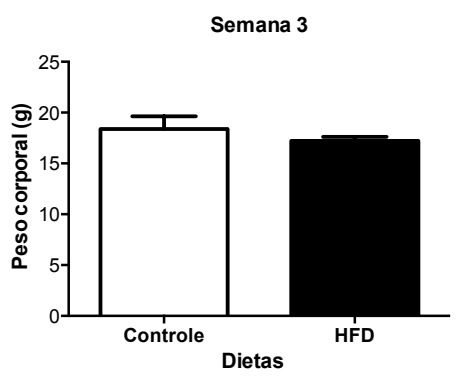

B

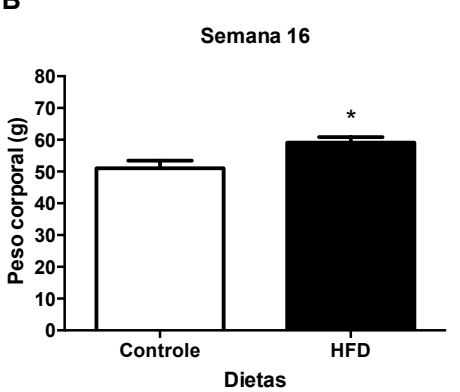

Figura 1: Efeito da dieta HFD no peso corporal $(g)$ dos animais que receberam dieta controle $(n=4)$ ou dieta hiperlipídica (HFD, $n=18$ ) do desmame até a idade adulta. Dados obtidos na $3^{\mathrm{a}}(\mathrm{A})$ e na $16^{\mathrm{a}}$ (B) semana. Os resultados estão expressos como média e erro-padrão da média. * $p<0,05$ vs. grupo controle.

Os animais do grupo HFD também apresentaram, na $16^{a}$ semana de vida, maior glicemia em jejum quando comparados ao grupo controle (Figura 2).

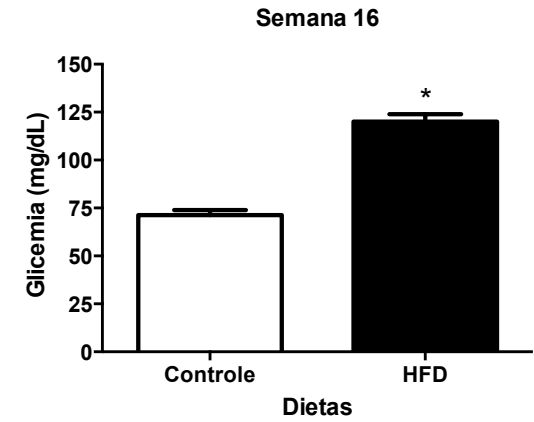

Figura 2: Efeito da dieta HFD na glicemia em jejum $(\mathrm{mg} / \mathrm{dL})$ dos animais que receberam dieta controle $(n=4)$ ou dieta hiperlipídica (HFD, $n=18)$ do desmame até a idade adulta. Os resultados estão expressos como média e erro-padrão da média. ${ }^{*} p<0,05$ vs. grupo controle.

Estes resultados mostram que a dieta hiperlipídica induziu a obesidade e a resistência à insulina, confirmando o modelo experimental proposto. 


\subsection{MASSA CARDÍACA}

Nenhuma das concentrações de GQ-16 administradas alterou a massa cardíaca total. Entretanto, a dieta hiperlipídica aumentou essa variável em comparação ao grupo que recebeu dieta normolipídica. E a rosiglitazona diminuiu a massa cardíaca total em comparação ao grupo HFD que recebeu veículo. Além disso, não foram observadas diferenças na massa cardíaca em relação ao peso corporal total dos animais entre os grupos experimentais, embora o tratamento com rosiglitazona tenha mostrado uma tendência de redução desta variável (Figura 3).

A

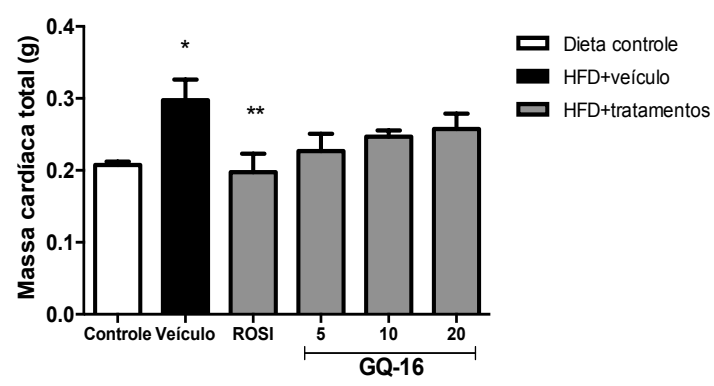

B

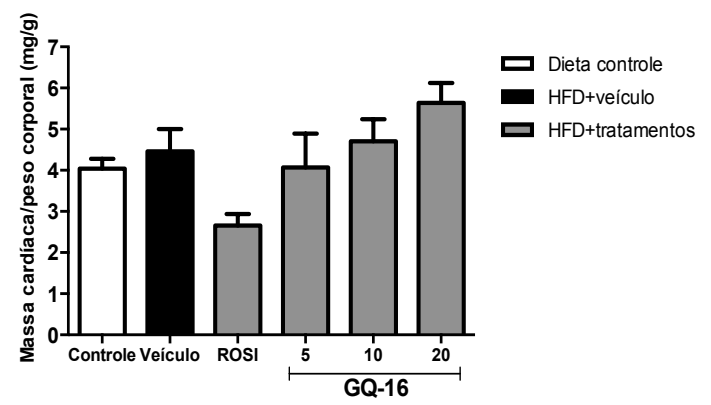

Figura 3: Massa cardíaca total $(\mathrm{g})(\mathrm{A})$ e massa cardíaca em relação ao peso corporal $(\mathrm{mg} / \mathrm{g})(\mathrm{B}) \mathrm{dos}$ animais que receberam dieta normolipídica (dieta controle $n=4$ ) ou dieta hiperlipídica (HFD, $n=18)$ do desmame até a vida adulta. Dados obtidos ao final da $18^{a}$ semana de vida dos animais. Os resultados estão expressos como média e erro-padrão da média. ${ }^{*} p<0,05$ vs. grupo controle, ${ }^{* *} p<0,05$ vs. grupo HFD + veículo. 


\subsection{EXPRESSÃO GÊNICA NO CORAÇÃO}

Ao se comparar os diferentes grupos experimentais, não foram observadas diferenças na expressão do marcador de adipócitos Fabp4 no coração dos animais (Figura 4).

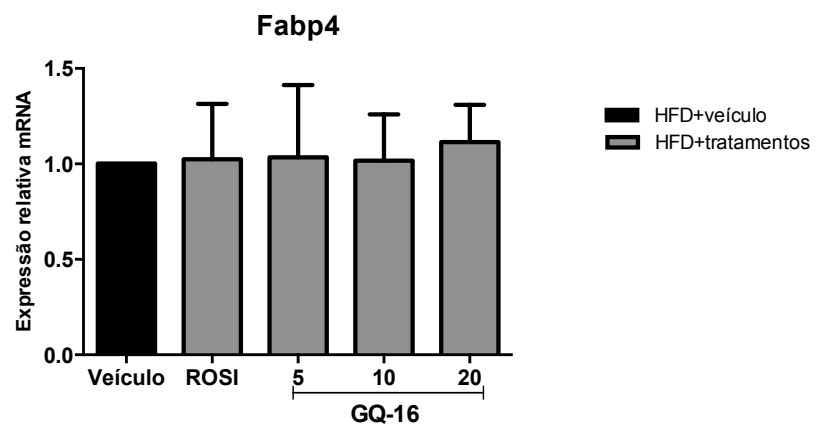

Figura 4: Expressão gênica relativa da Fabp4 no coração após o tratamento com veículo, rosiglitazona (ROSI, $4 \mathrm{mg} / \mathrm{kg} / \mathrm{dia}$ ) ou GQ-16 (5, 10 or $20 \mathrm{mg} / \mathrm{kg} / \mathrm{dia})$ por duas semanas ( 4 animais por grupo). 


\section{PERSPECTIVAS}

Os resultados do presente estudo mostram diferentes efeitos de agonistas de PPARy, total e parcial, sobre a massa cardíaca. Desta forma, mais estudos são necessários para elucidar o efeito de ligantes de PPARY com distintas propriedades farmacológicas no tecido cardíaco e, além disso, determinar as implicações destas diferenças.

Considerando que além de regular a adipogênese, a ativação do PPARY também está relacionada com efeitos anti-inflamatórios, a próxima etapa será avaliar os efeitos da rosiglitazona e do GQ-16 sobre a expressão de genes relacionados à inflamação no coração destes animais. 


\section{REFERÊNCIAS BIBLIOGRÁFICAS}

1. Danaei G, Finucane MM, Lu Y, Singh GM, Cowan MJ, Paciorek CJ, et al. National, regional, and global trends in fasting plasma glucose and diabetes prevalence since 1980: systematic analysis of health examination surveys and epidemiological studies with 370 country-years and 2.7 million participants. The Lancet. 2011;378(9785):31-40.

2. Guariguata L, Whiting DR, Hambleton I, Beagley J, Linnenkamp U, Shaw JE. Global estimates of diabetes prevalence for 2013 and projections for 2035. Diabetes Research and Clinical Practice. 2014;103(2):137-49.

3. IDF. International Diabetes Federation. Diabetes Atlas. 7th. Belgium: Brussels; 2015.

4. American Diabetes Association. Diagnosis and Classification of Diabetes Mellitus. Diabetes Care. 2010;33(Suppl 1):S62-S9.

5. Kung J, Henry RR. Thiazolidinedione safety. Expert Opinion on Drug Safety. 2012;11(4):565-79.

6. Nissen SE, Wolski K. Effect of Rosiglitazone on the Risk of Myocardial Infarction and Death from Cardiovascular Causes. New England Journal of Medicine. 2007;356(24):2457-71.

7. Grey A, Bolland M, Gamble G, Wattie D, Horne A, Davidson J, et al. The Peroxisome Proliferator-Activated Receptor-y Agonist Rosiglitazone Decreases Bone Formation and Bone Mineral Density in Healthy Postmenopausal Women: A Randomized, Controlled Trial. The Journal of Clinical Endocrinology \& Metabolism. 2007;92(4):1305-10.

8. Lehmann JM, Moore LB, Smith-Oliver TA, Wilkison WO, Willson TM, Kliewer SA. An Antidiabetic Thiazolidinedione Is a High Affinity Ligand for Peroxisome Proliferator-activated Receptor Y (PPARY). Journal of Biological Chemistry. 1995;270(22):12953-6.

9. Ahmadian M, Suh JM, Hah N, Liddle C, Atkins AR, Downes $M$, et al. PPAR[gamma] signaling and metabolism: the good, the bad and the future. Nat Med. 2013;99(5):557-66. 
10. Amato AA, Rajagopalan S, Lin JZ, Carvalho BM, Figueira ACM, Lu J, et al. GQ-16, a Novel Peroxisome Proliferator-activated Receptor y (PPARY) Ligand, Promotes Insulin Sensitization without Weight Gain. Journal of Biological Chemistry. 2012;287(33):28169-79.

11. Choi JH, Banks AS, Estall JL, Kajimura S, Bostrom P, Laznik D, et al. Antidiabetic drugs inhibit obesity-linked phosphorylation of PPAR gamma by Cdk5. Nature. 2010;466(7305):451-6.

12. Bruning JB, Chalmers MJ, Prasad S, Busby SA, Kamenecka TM, He Y, et al. Partial Agonists Activate PPARgamma Using a Helix 12 Independent Mechanism. Structure. 2007;15(10):1258-71.

13. Burgermeister E, Schnoebelen A, Flament A, Benz J, Stihle M, Gsell B, et al. A Novel Partial Agonist of Peroxisome Proliferator-Activated Receptor-y (PPARY) Recruits PPARy-Coactivator-1 $\alpha$, Prevents Triglyceride Accumulation, and Potentiates Insulin Signaling in Vitro. Molecular Endocrinology. 2006;20(4):809-30.

14. ANVISA. CARTA CIRCULAR No. 08 - GFARM/NUVIG/ANVISA/MS. Assunto: Cancelamento de registro do medicamento Avandia ${ }^{\circledR}$ (rosiglitazona). Agência Nacional de Vigilância Sanitária. 2010.

15. European Medicines Agency. European Medicines Agency recommends suspension of Avandia, Avandamet and Avaglim: Anti-diabetes medication to be taken off the market. European Medicines Agency. 2010.

16. Lipscombe LL, Gomes T, Levesque LE, Hux JE, Juurlink DN, Alter DA. Thiazolidinediones and cardiovascular outcomes in older patients with diabetes. JAMA. 2007;298(22):2634-43.

17. Graham DJ, Ouellet-Hellstrom R, MaCurdy TE, Ali F, Sholley C, Worrall C, et al. Risk of acute myocardial infarction, stroke, heart failure, and death in elderly medicare patients treated with rosiglitazone or pioglitazone. JAMA. 2010;304(4):4118.

18. Zhang H, Zhang A, Kohan DE, Nelson RD, Gonzalez FJ, Yang T. Collecting duct-specific deletion of peroxisome proliferator-activated receptor $\mathrm{Y}$ blocks thiazolidinedione-induced fluid retention. Proceedings of the National Academy of Sciences of the United States of America. 2005;102(26):9406-11.

19. Braissant O, Foufelle F, Scotto C, Dauca M, Wahli W. Differential expression of peroxisome proliferator-activated receptors (PPARs): tissue distribution of PPARalpha, -beta, and -gamma in the adult rat. Endocrinology. 1996;137(1):354-66. 
20. Marfella R, Portoghese M, Ferraraccio F, Siniscalchi M, Babieri M, Di Filippo $\mathrm{C}$, et al. Thiazolidinediones may contribute to the intramyocardial lipid accumulation in diabetic myocardium: effects on cardiac function. Heart. 2009;95(12):1020-2.

21. Duan SZ, Ivashchenko CY, Russell MW, Milstone DS, Mortensen RM. Cardiomyocyte-Specific Knockout and Agonist of Peroxisome Proliferator-Activated Receptor- $\gamma$ Both Induce Cardiac Hypertrophy in Mice. Circulation Research. 2005;97(4):372-9.

22. Son N-H, Park T-S, Yamashita H, Yokoyama M, Huggins LA, Okajima K, et al. Cardiomyocyte expression of PPARY leads to cardiac dysfunction in mice. The Journal of Clinical Investigation. 2007;117(10):2791-801.

23. Togashi M. Células mesenquimais derivadas do tecido cardíaco de macacos possuem potencial de se diferenciarem em adipócitos. Unpublished Work. 2001; Universidade de Brasília(Brasília).

24. Diabetes Center. Type 2 diabetic patients undergoing heart transplantation and were taking TZDs had increased adipogenesis and/or lipid accumulation in the myocardium. Personal Communication. 2010; University of California(San Francisco, EUA).

25. Nolte RT, Wisely GB, Westin S, Cobb JE, Lambert MH, Kurokawa R, et al. Ligand binding and co-activator assembly of the peroxisome proliferator-activated receptor-[gamma]. Nature. 1998;395(6698):137-43.

26. Nagy L, Schwabe JWR. Mechanism of the nuclear receptor molecular switch. Trends in Biochemical Sciences. 2004;29(6):317-24.

27. da Costa Leite LFC, Veras Mourão RH, de Lima MdCA, Galdino SL, Hernandes MZ, de Assis Rocha Neves F, et al. Synthesis, biological evaluation and molecular modeling studies of arylidene-thiazolidinediones with potential hypoglycemic and hypolipidemic activities. European Journal of Medicinal Chemistry. 2007;42(10):1263-71.

28. AVMA. American Veterinary Medical Association - Guidelines for the Euthanasia of Animals. 2013.

29. Golden HB, Gollapudi D, Gerilechaogetu F, Li J, Cristales RJ, Peng X, et al. Isolation of Cardiac Myocytes and Fibroblasts from Neonatal Rat Pups. In: Peng X, Antonyak M, editors. Cardiovascular Development: Methods and Protocols. Totowa, NJ: Humana Press; 2012. p. 205-14. 
30. Janderová L, McNeil M, Murrell AN, Mynatt RL, Smith SR. Human Mesenchymal Stem Cells as an in Vitro Model for Human Adipogenesis. Obesity Research. 2003;11(1):65-74. 
ANEXO A - DOCUMENTO DE APROVAÇÃO PELA COMISSÃO DE ÉTICA NO USO DE ANIMAIS - CEUA/FM
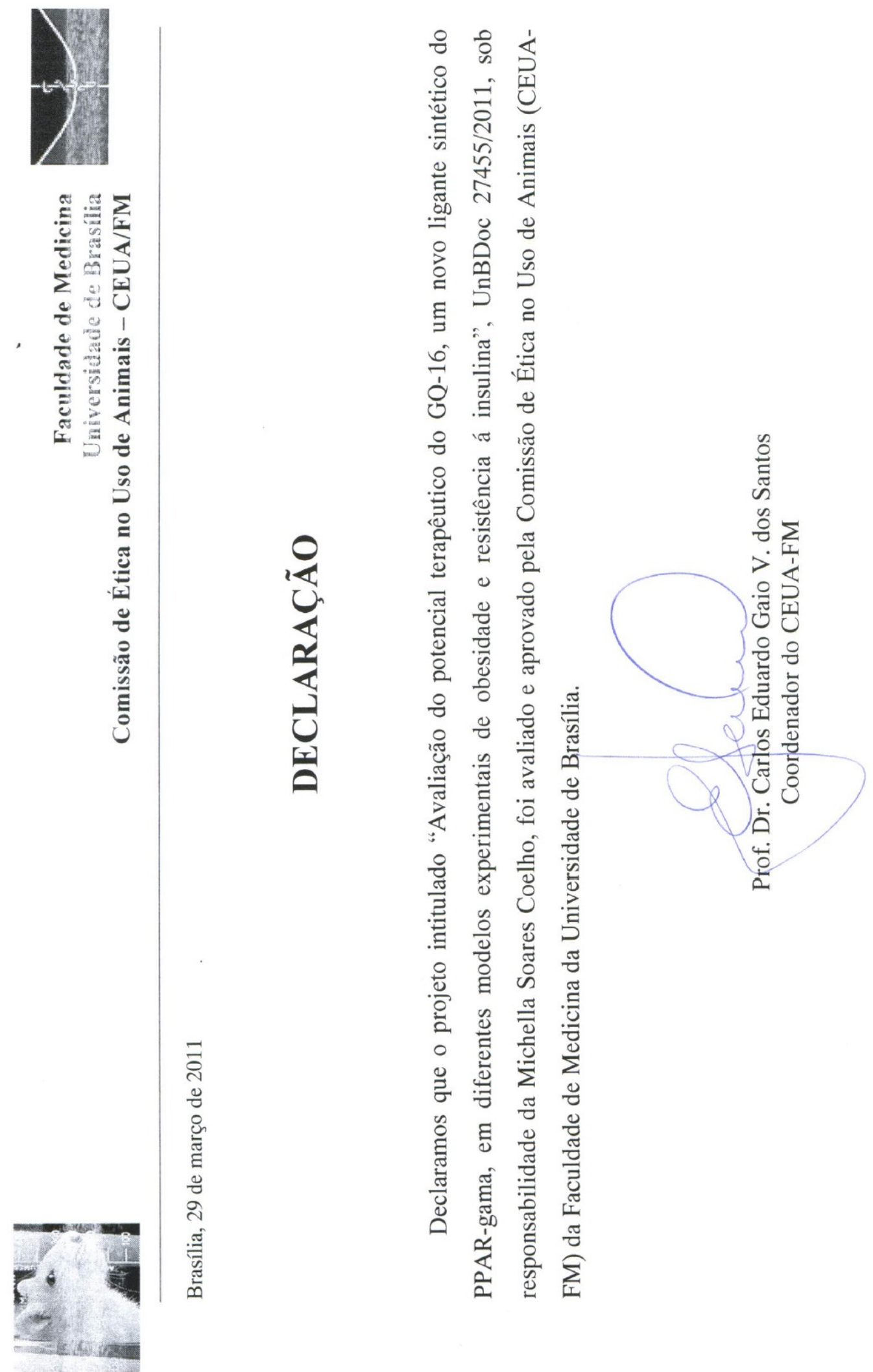